\title{
Projeto de Uma Ferramenta de Auxílio na Depuração de Programas Paralelos
}

\author{
Edmilson Marmo Moreira
}

Orientadora: Profa. Dra. Regina Helena Carlucci Santana

Dissertação apresentada ao Instituto de Ciências Matemáticas e de Computação - ICMC-USP, como parte dos requisitos para obtenção do título de Mestre em Ciências - Área: Ciências de Computação e Matemática Computacional. 
Dedico esta Dissertação à minha esposa Karina da Costa Cinquetti Moreira. 
A DEUS,

Inteligência Suprema causa primária de todas as coisas e a Jesus, Mestre dos Mestres, que passou entre os homens sem nada cobrar por Seus Divinos Ensinamentos. 


\section{Agradecimentos}

A minha orientadora Profa. Dra. Regina Helena Carlucci Santana, pela cuidadosa orientação e pela confiança que sempre depositou em mim...

Ao Prof. Dr. Marcos José Santana, pelos conselhos e sugestões...

Aos meus Pais Antonio e Terezinha, meus primeiros mestres... Eu amo vocês...

Ao meu filho Lucas, minha maior conquista...

Aos meus irmãos Leonardo e Eduardo, acima de tudo amigos...

Ao meu irmão Mauro, amigo de tantos caminhos e tantas jornadas...

Aos Professores Alexandre e Marly, pelo incentivo durante todos esses 11 anos que nos conhecemos...

Ao amigo Tomás Dias Santana, companheiro de testes e depuração de programas paralelos...

Aos meus alunos da Unifenas, razão por eu estar aqui...

Aos funcionários do ICMC, pelo carinho e respeito...

Aos colegas do $L A S D P C$, a família que encontrei em São Carlos...

Aos meus amigos Clóvis, Jonatas, Rony, Giovana, Toninho e Alexandre, companheiros do meu ideal maior...

A Universidade de São Paulo, pela oportunidade...

A Universidade de Alfenas, meu segundo lar... 


\section{Resumo}

O uso da programação paralela tem crescido muito nos últimos anos. Isso se deve, entre outros fatores, ao aumento da utilização dos sistemas distribuídos. Entretanto, esse tipo de programação apresenta maior complexidade em relação à programação seqüencial, o que dificulta a sua popularização. Um problema encontrado na programação paralela é o não determinismo global, que torna a depuração desses programas uma tarefa dificil. Além disso, a aprendizagem dos conceitos que envolvem a programação paralela por usuários sem muita experiência não é uma tarefa trivial.

Dentro desse contexto, este trabalho apresenta o projeto de uma ferramenta para depuração de programas paralelos. Essa ferramenta, além de permitir a depuração de um programa, auxilia os usuários sem muita experiência a analisar o código de seus programas, conduzindo-os a uma reformulação de suas técnicas de programação. Esse procedimento permite a aquisição de novos conhecimentos sobre a prática da programação paralela ou ainda consolidar conceitos anteriormente adquiridos.

Um protótipo da ferramenta proposta foi desenvolvido com o objetivo de avaliar a interface e a facilidade com que os usuários interagem com o ambiente, verificando assim o potencial da ferramenta. 


\section{Abstract}

The use of parallel programming had increased over the last years. This is mainly due, to the increase in the use of distributed systems. However, the parallel programming presents larger complexity in relation to the sequential programming, making its popularization difficulty. One problem found in the development of parallel software is the non-determinism that turns the debugging of those programs a difficult task. Furthermore, the learning of the concepts involved with parallel programming for inexperienced users is not a trivial task.

Thus, this MSc. dissertation presents the project of a tool aiming at debugging parallel programs. This tool, besides allowing the debugging of a parallel program, helps the inexperienced users in the analyzes of their program code, driving them towards a reformulation of their programming techniques. This procedure allows either the acquisition of new knowledge on the practice of the parallel programming or it can consolidate previous knowledge.

A prototype was also developed to evaluate both the interface built and the easiness in the users environment interaction, verifying the potential of the tool. 


\section{Sumário}

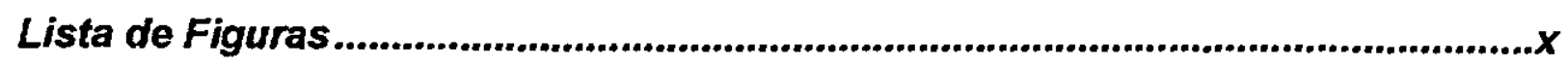

Relação de Listagens ...........................................................................................

Lista de Tabelas...............................................................................................xiii

\section{Capitulo 1}

Introdução....................................................................................................1

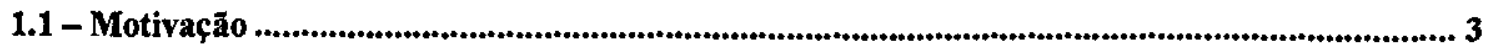

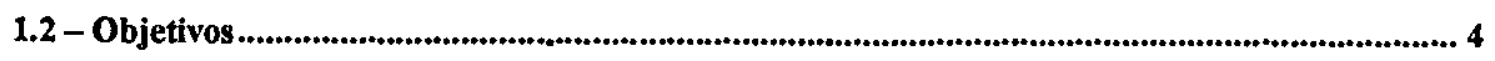

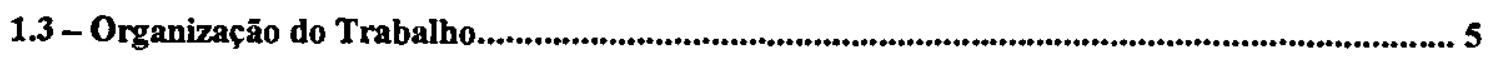

\section{Capitulo 2}

Programação Paralela........................................................................................6

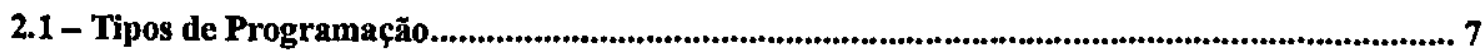

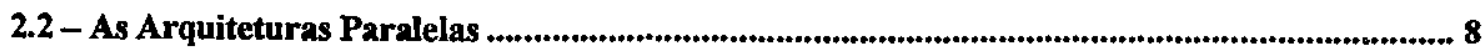

2.3 - Granulosidade ..........................................................................................................................10

2.4 - Mecanismos de Sincronizaçảo e Comunicação ..................................................................11

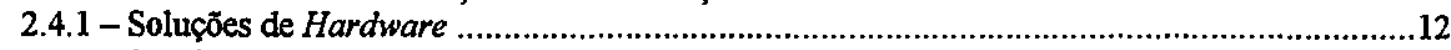

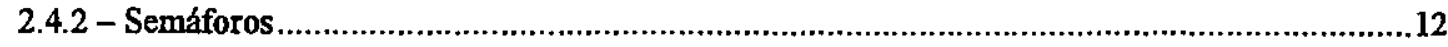

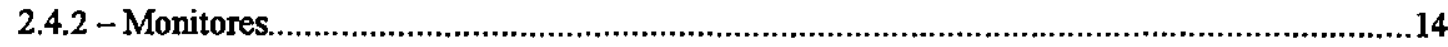

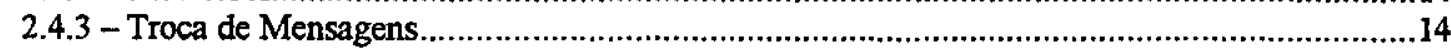


2.5 - A Elaboração de Um Programa Paralelo .............................................................................15

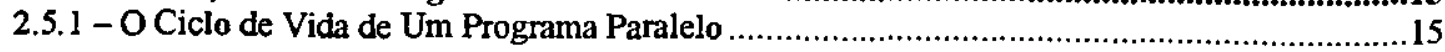

2.6 - Plataformas de Portabilidade............................................................................................17

\section{Capítulo 3}

Depuração de Programas Paralelos.

3.1 - Características Especiais na Depuração dos Programas Paralelos...........................................21

3.2 - Abordagens Clássicas na Depuraçảo de Software ......................................................................23

3.3 - Classificaçåa dos Depuradores para Programas Paralelos.........................................................25

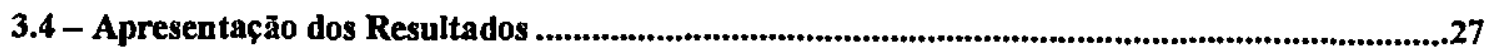

3.5 - Consideraçð̄es Sobre os Sistemas Distribuídos .................................................................29

\section{Capítulo 4}

Deadlock 31

4.1 - Deadlock e Depuração de Programas Paralelos ....................................................................32

4.2 - Condiçōes Para a Ocorrência de Deadlocks .........................................................................33

4.3 - Detecção de Deadlocks........................................................................................................34

4.4 - Deadlocks em Sistemas Distribuídos..................................................................................38

\section{Capitulo 5}

Interface Homem-Máquina e Sistemas Tutores................................................39

5.1 - Interface Homem-Máquina .............................................................................................39

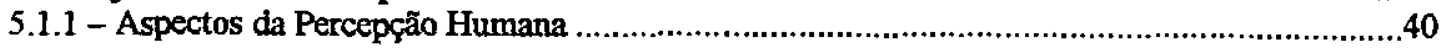

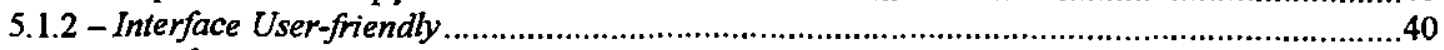

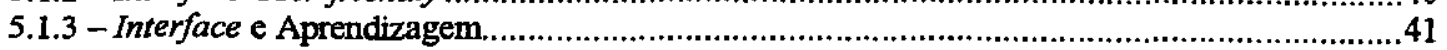

5.1 .4 - Construção de Uma Interface .............................................................................

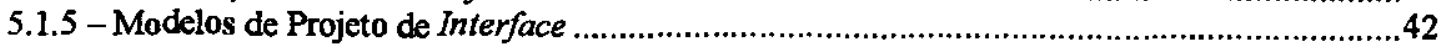

5.2 - Sistemas Tutores e Sistemas Tutores Inteligentes..........................................................42

5.2.1 - A Arquitetura de um Sistema Tutor Inteligente .................................................43

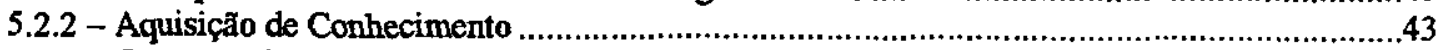

5.2.3 - O Ensino da Programação de Computadores Através de Um S.T.I...................................43 


\section{Capítulo 6}

O Projeto de Um Ambiente Para Depuração de Programa Paralelos .45

6.1 - O Modelo da Ferramenta .......................................................................................................44

6.1.1 - Processo 1 - Preparar Dados de Arquitetura e Biblioteca ................................................50

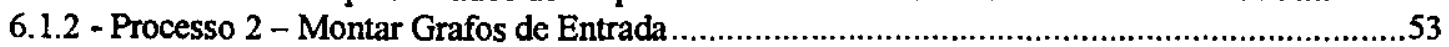

6.1 .3 - Processo 3 - Depurar o Programa........................................................................60

6.1.4 - Processo 4 - Criar Ambiente Tutor....................................................................64

6.1.5 - Processo 5 - Montar Grafos de Simulação......................................................65

6.2 - Consideraçōes Finais ...................................................................................................67

\section{Capitulo 7}

O Desenvolvimento de Um Prototipo ....................................................................68

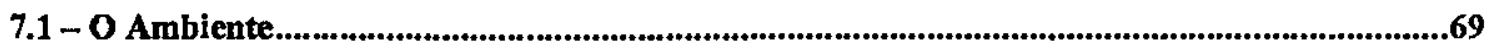

7.2 - Representan do um Algoritmo Através de Um Grafo........................................................71

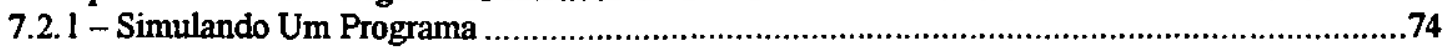

7.3 - Estrutura Interna do Protótipo ...................................................................................77

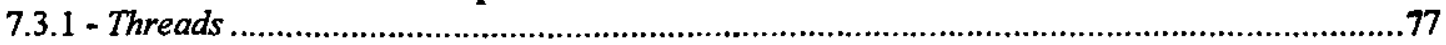

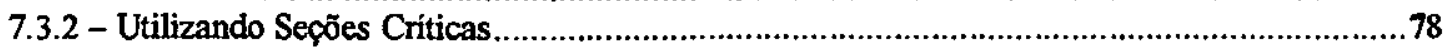

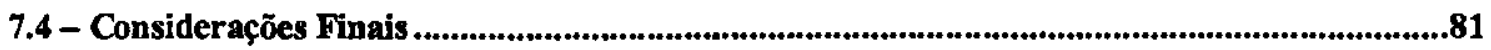

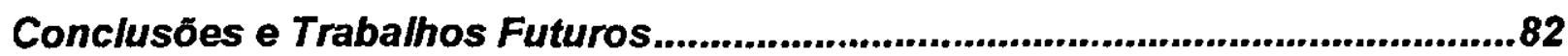

Referências Bibliográficas ...................................................................................85 


\section{Lista de Figuras}

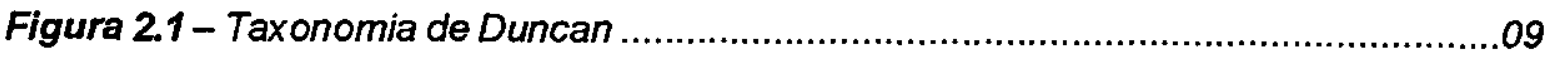

Figura 4.1 - Grafos de alocação de recursos ........................................................35

Figura 4.2 - Um digrafo de recursos com a ocomência de um ciclo .............................37

Figura 6.1 - As camadas que definem o projeto .......................................................46

Figura 6.2 - Estrutura dos Fluxose dos Dados da Ferramenta $\left(1^{\circ}\right.$ Modelo) .................48

Figura 6.3 - Estrutura dos Fluxos e dos Dados da Ferramenta (Modelo Final) ............4.49

Figura 6.4 - Explosão do Processo 1 - Preparar Dados da Arquitetura e Biblioteca ....51

Figura 6.5 - Grafo do Fluxo de Instruções da Listagem 6.1 ........................................57

Figura 6.6 - Grafo do Fluxo de Instruções da Listagem 6.2 .......................................58

Figura 6.7 - Grafo do Fluxo das Comunicações dos Processos da Listagem 6.2 .........59

Figura 6.8 - Explosão do Processo 2 - Montar Grafos de Entrada ...............................60

Figura 6.9 - Explosão do Processo 3 - Depurar o Programa ....................................61

Figura 6.10 - Grafo do Fluxo das Comunicações dos Processos da Listagem 6.3 ......63

Figura 6.11 - Grafo do Fluxo das Comunicações das Tarefas da Listagem 6.4 ...........64

Figura 6.12- Explosão do Processo 5-Montar Grafos de Simulação .........................66

Figura 7.1 - Teia Principal do Ambiente de Depuração de Programas Paralelos .........69

Figura 7.2 - As Principais Funções do Ambiente de Depuração de Programas Paralelos .......................................................................................... 70

Figura 7.3 - Entrada dos Dados da Arquitetura e da Biblioteca ..................................71

Figura 7.4 - Exemplo de Grafo e Sua Representação através de Uma Matriz de Adjacência ....................................................................................... 72

Figura 7.5 - Exemplo de Grafo e Lista de Adjacência Correspondente .........................73

Figura 7.6 - Algontmo Aberto Pelo Protótipo ........................................................... 75

Figura 7.7 - Exemplo de Aplicação Paralela Aberta no Protótipo .................................76 
Figura 7.8 - Tarefas Bloqueadas Aguardando Liberaçăo Pelo Usuário .......................76

Figura 7.9 - Estado dos Processos da Figura 7.8 ...........................................77 


\section{Relação de Listagens}

Listagem 2.1 - Primitivas Down e Up .............................................................13

Listagem 6.1 - Programa Exemplo Para Criação de Grafo .........................................56

Listagem 6.2 - Exemplo de Troca de Mensagens Entre Processos ............................58

Listagem 6.3 - Exemplo de Processos Livres do Problema de Espera Infinita ............62

Listagem 6.4 - Processos em Deadlock ...............................................................63

Listagem 7.1 - Estrutura da Lista de Adjacências Implementada no Protótipo .............74

Listagem 7.2 - Definição da Classe ThProcesso Implementada no Protótipo................79

Listagem 7.3 - Declaração e Inicialização da Seção Crítica e da Variável PCB .......... 80 


\section{Lista de Tabelas}

Tabela 6.1 - Estrutura de Programas e a Representação Através de Grafos .55 



\section{Capítulo 1 \\ Introdução}

Esta é uma época incrivel. Pode-se notar, através da história, que a evolução humana caminha em progressão geométrica. $\mathrm{E}$ isto ocorre porque há cada descoberta do homem, cada conhecimento novo cria condiçōes para novos saltos, conquistas ainda maiores, e estas novas conquistas não se realizariam sem as bases anteriores.

Dando luz a essas considerações, o Homo Sapiens surgiu na Terra por volta de 35000 anos atrás. Nesta época, o homem já possuía alguns rudimentos de aquisição intelectual, haja visto que nas paredes das cavernas desse tempo, foram encontrados os primeiros testemunhos pictóricos expressando sentimentos fortemente enraizados [Seleções, 1975]. Dividindo-se esses 35000 anos de história por 60, que representa a expectativa média de vida, encontra-se um valor aproximado de 590 gerações. Sessenta anos é um valor aleatório, já que a expectativa de vida mudou muito durante esses anos, visto que os primeiros homens viviam pouco, um em cada dez sobrevivia aos 40 anos, raramente se encontraria alguém com 50 anos. Destas quase 600 gerações, o homem viveu a maior parte delas dentro de cavernas, em uma vida nômade, sobrevivendo quase que exclusivamente da caça e da pesca. $O$ domínio do conhecimento da agricultura só apareceu por volta de 10000 anos a.C. há quase 200 gerações.

Cerca de 6000 a.C. no Irão e na Turquia, os habitantes de Catal Hüyük, no sul da Turquia, já fundiam cobre e chumbo [Seleções, 1975]. Procedimento que viria a ter conseqüências enormes em toda a Humanidade: a libertação do homem de sua longa idade da pedra (há 140 gerações).

$\mathrm{Na}$ sua maioria, as grandes realizações da humanidade, que perduraram até hoje, ocorreram entre as grandes civilizaçōes, que existiram nos últimos 5000 anos (aproximadamente 85 gerações). A civilização iniciou-se entre os povos que viviam no Médio 
Oriente, em solos férteis particularmente propicios à agricultura que, em conseqüência, exigia uma vida mais sedentária, já que as sementeiras necessitavam de tempo para se desenvolverem. Os agricultores construíram as primeiras vilas, que viraram cidades; a palavra “civilização" significou, primitivamente, "viver em cidades".

Sem dúvida que a grande descoberta humana desta época foi a escrita. O homem, por viver em sociedade, sempre buscou formas de melhorar a sua comunicação. Com o surgimento da escrita, as ciências como a matemática e medicina, tiveram um progresso significativo. A grande dificuldade de entender o comportamento do homem primitivo, é justamente, não existir relatos que possam ser interpretados além das pinturas das cavernas.

A história da humanidade é uma saga de descobrimentos, lutas, conquistas, passando pelas civilizações antigas, como as cidades gregas e o glorioso império romano. Mas foi no Renascimento, com a invenção da imprensa por Hans Guttenberg (1398-1468), publicando a primeira obra: a Biblia latina (1456), que a humanidade realmente disparou na curva do progresso. Desde esse momento, a informação foi se tornando cada vez mais presente na vida de cada homem. $E$ isto aconteceu a apenas 24 gerações.

Quanto crescimento realizado nas últimas 20 gerações. As observações de Galileu Galilei (1564-1642). A genialidade de Newton (1642-1727). A seleção natural de Charles Darwin (1809-1882). A descoberta da natureza do átomo por John Dalton (1766-1844). As invenções de Thomas Alva Edison (1847-1931), patenteadas foram 1093. Quantos homens, quantas vitórias.

Ao olhar ao seu redor, o homem pode perceber que a maioria das coisas que são utilizadas foram criadas na última geração (últimos sessenta anos). $\mathrm{O}$ homem do século passado nascia e morria sobre o lombo de um cavalo. E olhando para um futuro próximo, daqui a dois ou três anos, é impossível prever como estará a humanidade.

A ciência da computação, como se apresenta hoje, é uma área moderna. Não participou de todas estas conquistas da história, mas é impossível imaginar um mundo a partir de hoje sem a sua presença.

O conhecimento não surge do nada. É preciso criar condições, propor hipóteses, testar, negar. O mundo que se observa nos dias atuais, é fruto de uma grande caminhada que começou antes mesmo do surgimento do Homo Sapiens. A informática não surgiu das lutas desse século, fez parte das técnicas que os pastores primitivos usavam para contar suas ovelhas. Está ligada nos fundamentos que promoveu a criação do ábaco. Acelerou a sua evolução com Blaise Pascal (1623-1662) e sua máquina de calcular em 1642, passando pelo projeto de Charles Babbage (1792-1871) de uma máquina para realizar cálculos poderosos. 
Os teclados atuais, com tantas funções e as impressoras poderosas, fazem recordar a primeira máquina de escrever Remington, concebida por C. Sholes (1816-1867) com um teclado simples que só permitia escrever maiúsculas. As discussões sobre a velocidade de comunicação que as redes utilizam reportam aos estudos de investigação dos fenômenos electromagnéticos, realizados na Europa e na América no início do século passado. Esses estudos resultaram nas descobertas que viriam a dar origem ao telégrafo, ao telefone, ao rádio e a televisão.

Qualquer descoberta científica não é um fato isolado. É resultado de anos de experiência. Para se realizar um trabalho de pesquisa é preciso contextualizá-lo. Acima de tudo, é preciso entender que todo conhecimento novo necessita de um conhecimento anterior que o sustente. Por isso o homem levou tanto tempo para sair das cavernas, mas nos dias de hoje, surgem descobertas novas a cada momento.

Contribuir de alguma forma com a ciência é deixar de ser mero espectador para atuar no mundo.

\section{1 - Motivação}

O homem caminha do egocentrismo para o altruismo. Necessita viver em sociedade e enfrenta os desafios que a cooperação impõe. Em várias ocasiões, não consegue trabalhar em equipe, e encontra dificuldades para trocar informações.

$\mathrm{Na}$ computação isto também acontece. Muito mais fácil criar um programa seqüencial, que realiza uma série de tarefas para se atingir um fim comum, do que vários programas que possam cooperar entre si, diminuindo a carga individual e aumentando a produtividade e o desempenho. Isto porque é dificil pensar em termos de conjunto, de compartilhar tarefas, de sincronizar ações, de dividir o prêmio pelo sucesso.

A programação paralela apresenta inúmeras vantagens em relação à programação seqüencial, entretanto, os motivos que ainda restringe o seu uso são relativamente fortes.

Um motivo que já está saindo de moda é a necessidade de hardware específico, ou seja, de máquina paralela para executar um programa paralelo. Esta situação existia até bem pouco tempo, porém com o advento dos sistemas distribuídos que estão ao alcance de todos, a programação paralela passou a ser, não só uma realidade, mas principalmente, uma necessidade para que esses sistemas possam ser usados com maior eficiência.

Outro motivo, é que programar paralelamente exige conhecimentos específicos, que muitos programadores não possuem. Isto restringe o número de profissionais que produzem esse tipo de software. Além disso, os conceitos que envolvem a programação paralela ainda se 
encontram circunscritos nas Universidades e Centros de Pesquisa, dificultando a popularização desses conhecimentos.

Em adição, as ferramentas de desenvolvimento de programas paralelos que existem não são tão fáceis de utilizar e nem apresentam tantos recursos quanto às ferramentas de desenvolvimento seqüenciais, que já estão fortalecidas no mercado.

Desta forma, despender esforços para popularizar a programação paralela, através do desenvolvimento de ferramentas de auxilio aos usuários e ampliar o estudo das técnicas envolvidas no desenvolvimento de um software paralelo, objetivando encontrar soluções mais simples e práticas, proporciona um ambiente propício e a motivação necessária para o desenvolvimento de um trabalho como esse.

\section{2 - Objetivos}

Diante das dificuldades que os estudantes de programação concorrente encontram na depuração de seus códigos, é proposto este trabalho que envolve duas áreas de atuação diferentes: a depuração de programas paralelos e o ensino da programação paralela.

O objetivo é criar uma ferramenta que auxilie um usuário de programação concorrente, sem muita experiência, a localizar erros em programas paralelos. Mas a ferramenta deve ainda, possibilitar o aumento do conhecimento do usuário durante a sua utilização. Ou seja, a ferramenta a ser desenvolvida não é um mero depurador de programas paralelos, mas uma ferramenta que induza o usuário a descobrir seus erros. Desta forma, acredita-se que além de localizar erros em seus programas, o programador estará aprendendo como fazê-lo.

Criar ferramentas que auxiliem o usuário resolver os problemas que surgem durante o desenvolvimento de um software paralelo é importante, mas é fundamental capacitá-lo a desenvolver software mais confiáveis, através do treinamento que pode ser alcançado com a própria análise de seus erros com sugestões e comentários da forma ideal de se realizar aquele trabalho.

Muitas atividades têm sido desenvolvidas recentemente sobre computação paralela, porém os rumos de tal tecnologia de programação ainda estão se definindo, por falta de uma metodologia efetiva de programação. Desenvolver programas eficientes para computadores paralelos é dificil devido à complexidade e variedade das arquiteturas paralelas.

É preciso um esforço conjugado na busca de soluções simples e práticas para auxiliar na construção de software paralelos. Estas ferramentas precisam ser divulgadas para que as idéias não fiquem apenas na Academia, mas possam ser efetivamente utilizadas por aqueles que necessitam de apoio na confecção de seus sistemas. 
A depuração de programas paralelos não é uma tarefa simples. E sua difusão está diretamente relacionada com a popularização dos software paralelos e o surgimento de ferramentas mais amigáveis para o seu desenvolvimento.

A ferramenta é composta de módulos funcionais que resolvem tipos diferentes de problemas encontrados nos programas paralelos como deadlock e sincronismo entre as tarefas.

Inicialmente é definido um modelo de alto nivel com as relações dos diversos módulos. As especificações desses módulos permitem que eles possam ser implementados nas diversas linguagens e bibliotecas existentes para a criação de software paralelo, particularmente em sistemas distribuídos ou ambientes com mecanismos de troca de mensagem.

\section{3 - Organização do Trabalho}

0 trabalho está organizado da seguinte forma:

o próximo capitulo faz uma apresentação geral dos conceitos que envolvem a programação paralela. O capítulo 3 apresenta um estudo sobre depuração de programas paralelos, mostrando as técnicas que existem nos diferentes tipos de ferramentas para depuração. No capitulo 4 é discutido o problema denominado deadlock, enfocando sua ocorrência nos programas paralelos. $\mathrm{O}$ capitulo $5 \mathrm{faz}$ uma introdução dos assuntos software tutor e interface de software. O capitulo 6 descreve o projeto da ferramenta de auxilio na depuração de programas paralelos. No capítulo 7 é apresentado o desenvolvimento de um protótipo. E o último capítulo apresenta o comentário final deste trabalho, mostrando as suas contribuições e propostas para trabalhos futuros.

Alguns termos foram mantidos conforme o original em inglês, na tentativa de não prejudicar a legibilidade do texto. 


\section{Capítulo 2 \\ Programação Paralela}

Até bem pouco tempo, não se ouvia falar em programação paralela com muita freqüência. A maioria dos desenvolvedores não tinha acesso a máquinas paralelas e as técnicas de programação que eles utilizavam se baseavam nos conceitos da programação seqüencial.

Nos dias atuais, a programação paralela está cada vez mais correlacionada aos sistemas distribuídos e o aumento na sua utilização está diretamente relacionada com a crescente popularização desse tipo de sistema. Ela está deixando os ambientes "elitizados" onde se encontrava até bem pouco tempo, como as universidades, centros de pesquisa e grandes empresas que tinham condições de adquirir supercomputadores que a maioria das pessoas sequer conheciam, para uma maior atuação nos diversos campos de aplicação da ciência em geral.

É fácil entender o grande interesse pela programação paralela, afinal ela está associada com o alto desempenho que todos os usuários buscam. Durante anos, o desempenho foi sinônimo de aumento no poder de processamento dos computadores. Atualmente, o desempenho pode ser conseguido através da otimização dos programas, além da paralelização dos códigos, na maioria seqüenciais, para o uso em sistemas distribuídos, que podem simular máquinas paralelas.

Muitas empresas possuem a estrutura para implantar um sistema distribuído, mas não fazem isso porque seus software não exploram o paralelismo, sendo códigos estritamente seqüenciais e seus programadores não sabem trabalhar com programas paralelos. Aliás, esta é a grande dificuldade para a popularização da computação paralela e de certa forma, também dos sistemas distribuídos, ou seja, a falta de conhecimento dos desenvolvedores, com relação 
a estas técnicas.

Implementar um algoritmo sobre um computador paralelo, ou mesmo sobre um sistema distribuído, necessita de recursos de programação paralela para expressar o paralelismo entre as tarefas e incluir mecanismos para sincronização e comunicação destas tarefas.

\section{1 - Tipos de Programação}

Qual é a dificuldade encontrada pelos programadores para mudar o paradigma da programação seqüencial para a programação paralela? Antes de responder, é preciso diferenciar esses dois tipos de programação. Um Programa seqüencial é uma lista de comandos que são executados, instrução após instrução, para se atingir um objetivo proposto. Um processo é geralmente definido como um programa seqüencial que está executando. Um programa paralelo é um conjunto de programas seqüenciais que trabalham juntos e que possuem mecanismos que permitem a esses programas trocarem informações e se sincronizarem, para atingir um objetivo comum. Em um sistema com multiprogramação podem existir muitos processos executando em um determinado momento, mas não formam necessariamente um programa paralelo, pois cada um está buscando atingir um objetivo que lhe é próprio. Neste trabalho, os processos que compõem um programa paralelo serão chamados de tarefas, para diferenciar dos processos seqüenciais.

É comum ainda, a utilização do termo programação concorrente. Quando um programa paralelo executa em uma máquina com apenas um processador, o sistema operacional necessita escalonar as tarefas do programa paralelo, criando um pseudoparalelismo, permitindo que o desenvolvimento das tarefas possa se dar de forma concorrente. Daí o termo programação concorrente. Quando uma máquina paralela possui um número de processadores em quantidade menor que o número de tarefas que compõe um programa paralelo, ocorrem as duas situações, ou seja, existem várias tarefas concorrendo ao uso dos processadores em um ambiente paralelo.

Em termos de programação não existem diferenças entre programação concorrente e programação paralela, sendo os dois termos utilizados indistintamente nesta monografia. É evidente que as técnicas de programação recebem influência da arquitetura utilizada, provocando algumas diferenças na codificação. Por exemplo, em um programa paralelo, sendo executado em uma máquina com apenas um processador, portanto concorrente, existe apenas um endereçamento de memória, que é compartilhado por todas as tarefas da aplicação. Nesse caso, as políticas de sincronização e comunicação que deverão ser utilizadas serão 
aquelas próprias para os sistemas fortemente acoplados, como semáforos e monitores, que serão discutidos no item 2.4. Se o mesmo programa executar em um sistema distribuido, a comunicação só poderá ser feita por mecanismos de troca de mensagens.

Respondendo a pergunta efetuada no primeiro parágrafo desta seção (2.1). Existem várias razões para explicar a dificuldade que os programadores encontram para migrar da programação seqüencial para a programação paralela. Uma delas é a própria característica das linguagens seqüenciais que evoluiram muito, proporcionando um ambiente de desenvolvimento amigável, que facilita a criação dos programas e a sua depuração caso seja constatado algum problema. Muitas linguagens paralelas, ainda são escritas em editores com poucos recursos (se comparadas as linguagens seqüenciais), separados do compilador que, geralmente, é acionado por linhas de comandos complexas.

É preciso considerar ainda, que as linguagens paralelas não possuem a mesma quantidade bibliográfica se comparadas às linguagens puramente seqüenciais. Esta situação desencoraja o programador ainda inexperiente e que sente dificuldade em entender os conceitos que envolvem a programação paralela. Além disso, um programa que executa como se espera em uma arquitetura paralela, se for compilado para executar em uma outra, pode não alcançar o mesmo desempenho, ou seja, o desenvolvedor, além de saber programar, deve entender que não se faz programação paralela separada da arquitetura paralela.

Já que a arquitetura em que um programa paralelo está executando interfere diretamente nas técnicas de programação, será feita uma breve introdução sobre o tema.

\section{2 - As Arquiteturas Paralelas}

As arquiteturas paralelas têm se apresentado como o futuro para computação de alto desempenho nas mais diversas aplicações. A barreira para sua difusão, como já foi colocado, é que escrever programas paralelos que sejam eficientes e portáveis é muito dificil. A programação paralela apresenta uma complexidade muito maior que a programação seqüencial porque programas paralelos não somente expressam a computação seqüencial, mas também as interações entre as tarefas que definem o paralelismo [Browne et al., 1995].

Diversas taxonomias para arquiteturas paralelas foram propostas. As duas mais utilizadas são a de Flynn [Flynn, 1972] e a de Duncan [Duncan, 1990]. Com o objetivo de abranger os computadores vetoriais e as arquiteturas híbridas, que não foram detalhados na classificação de Flynn, Duncan apresentou uma taxonomia mais abrangente, mostrada na figura 2.1. 
Figura 2.1 - Taxonomia de Duncan.

Sincronos $\left\{\begin{array}{l}\text { Vetoriais } \\ \text { SIMD } \\ \text { Sistólicas }\end{array}\left\{\begin{array}{l}\text { Processador Matricial } \\ \text { Memória Associativa }\end{array}\right.\right.$
MIMD

A classificação de Flynn enxergava o processo computacional como uma relação entre os fluxos de instrução e os fluxos de dados. Por fluxo de instrução, deve-se entender a sequêencia de instruções executadas sobre um fluxo de dados relacionados. Flynn considerou a unicidade e multiplicidade dos fluxos de dados e instruções. Através das combinações possiveis Flynn chegou a quatro classes de arquiteturas:

(1) SISD (Single Instruction Stream / Single Data Stream) que representa o modelo tradicional von Neumann. Nesta classificação um processador executa, de maneira seqüencial, um conjunto de instruções sobre um conjunto de dados;

(2) SIMD (Single Instruction Stream / Single Data Stream) que possui vários processadores controlados por uma única unidade de controle. Executam simultaneamente a mesma instrução em diversos conjuntos de dados;

(3) MISD (Multiple Instruction Stream / Single Data Stream) que envolve vários processadores executando diferentes instruções em um único conjunto de dados; e

(4) MIMD (Multiple Instruction Stream / Multiple Data Stream) que apresenta vários processadores executando diferentes instruções em diferentes conjuntos de dados, de maneira independente. Esta classe engloba a maioria dos computadores paralelos.

Em relação à classificação de Flynn, Duncan ainda excluiu as arquiteturas que somente apresentassem fluxo único de instrução e fluxo único de dados (SISD - Single Instruction Single Data Stream), por se tratar de uma abordagem seqüencial e as arquiteturas MISD (Multiple Instruction Stream / Single Data Stream), pois não existe nenhuma 
arquitetura com esta abordagem. Além disso, Duncan separou as arquiteturas em Síncronas e Assincronas. As primeiras dizem respeito às arquiteturas que coordenam as operações paralelas sincronamente em todos os processadores, utilizando o mesmo relógio global e unidades de controle únicas. Já as arquiteturas assincronas possuem o controle descentralizado do harctware, proporcionando uma maior independência entre os processadores.

Entre os tipos de arquiteturas Síncronas, além das arquiteturas de classificação SIMD (Single Instruction Multiple Data Stream) proposta por Flynn, estão os Processadores Vetoriais que possuem um hardware específico para a manipulação de vetores $\mathrm{e}$ as Arquiteturas Sistólicas que possuem vários processadores dispostos em uma seqüência (pipeline), realizando o acesso a memória através dos processadores localizados nas extremidades desta cadeia.

Duncan ainda subdividiu a arquitetura SIMD em Processadores Matriciais, criados para computação sobre matrizes de processadores, e Memória Associativa, onde o acesso à memória é feito através do seu conteúdo e não através de endereçamento que é o mais comum.

Em sua taxonomia, Duncan dividiu as arquiteturas Assíncronas em MIMD e Paradigma MIMD. A arquitetura MIMD (Multiple Instruction, Multiple Data Stream), também já havia sido considerada por Flynn, mas Duncan ainda subdividiu esse tipo de arquitetura em Memória Distribuída e Memória Compartilhada. Esta divisão está relacionada à existência de uma memória única, onde todos os processadores podem ler e escrever em todas as posições, no caso de memória compartilhada, ou a existência de várias memórias, uma para cada processador, e que somente pode ser endereçada pelo processador correspondente, para as arquiteturas com memória distribuída.

As arquiteturas Paradigma MMD englobam todas as arquiteturas que, apesar de possuírem características MIMD, possuem detalhes muito específicos em seus projetos. Esse tipo de arquitetura foi subdividido em MIMD/SIMD ou híbridas, Fluxo de Dados, Redução e Frente de Onda.

\section{3 - Granulosidade}

Granulosidade, ou nível de paralelismo, é o termo usado para especificar o tamanho das tarefas que compõe um programa paralelo. A granulosidade está relacionada diretamente com a arquitetura utilizada e é dividida em grossa, média e fina. A granulosidade grossa relaciona o paralelismo ao nível de programas. Em sistemas distribuídos, por exemplo, é a 
granulosidade ideal, devido à necessidade de haver pouca comunicação entre as tarefas que estão executando em máquinas distintas na rede. A granulosidade fina relaciona o paralelismo ao nível de instruções, aplicando-se a arquiteturas fortemente acopladas através de memória centralizada e que possuem um grande número de processadores simples. A granulosidade média situa-se entre as duas anteriores.

A arquitetura e a granulosidade das tarefas repercutem diretamente nas técnicas a serem adotadas para programar paralelamente, devido aos mecanismos para comunicação que devem ser utilizados pelas tarefas que compõem a aplicação. A solução adotada, sob o ponto de vista de software, para uma arquitetura e sua granulosidade, pode ser completamente incompatível em uma arquitetura paralela com características diferentes. Por exemplo, uma transformação elementar que se deseja realizar em uma matriz de grandes dimensões. Se o programa estiver executando em uma arquitetura SIMD com hardware especifico para a manipulação de matrizes e um grande número de processadores simples, será interessante dividir a grande matriz em muitas matrizes pequenas, distribuindo-as para os diversos processadores. Se a mesma solução fosse adotada em uma arquitetura MIMD com memória distribuida, possuindo poucos processadores e se comunicando através de uma rede com pequena largura de banda, seria necessário muita comunicação entre os processadores, aumentando o gargalo da rede e produzindo um efeito muito pior. Uma solução seria a divisão do programa em um número de matrizes menores, na quantidade de processadores, mas ainda grandes o suficiente para compensar a transferência desses valores entre eles.

A arquitetura adotada influencia diretamente nas técnicas de comunicação e sincronismo que devem ser utilizadas em um programa paralelo. A seguir serão discutidos alguns dos mecanismos mais usados e em que situação eles se aplicam.

\section{4 - Mecanismos de Sincronização e Comunicação}

Como as tarefas que compõem um programa paralelo necessitam trabalhar em conjunto, buscando atingir um objetivo comum, fica evidente a necessidade destas tarefas trocarem informações. Também pode ser observado que em um trabalho coletivo, principalmente em um ambiente heterogêneo, as tarefas não executam com a mesma velocidade. Isto pode ser causado por vários fatores, como a carga do processador ou seu poder de processamento. Esta diferença na velocidade, em muitas situações, provoca a necessidade de sincronizar as tarefas através de bloqueios.

As técnicas que garantem a comunicação entre as tarefas (ou processos) e o acesso de recursos compartilhados são chamados de mecanismos de sincronização. A maioria dos 
problemas que ocorrem nos programas paralelos está vinculada a uma má utilização desses mecanismos durante a codificação.

Outro conceito importante que surge quando se estuda o problema da sincronização e comunicação entre os processos é a chamada Região Crítica. A região crítica é uma área do código de um processo que faz referência a dados compartilhados. Muitos problemas podem surgir quando vários processos realizam o acesso a dados ou recursos compartilhados de forma paralela ou concorrente. Alguns desses problemas serão vistos no capítulo 3, sobre a depuração de programas paralelos. Os mecanismos de sincronização devem evitar a concorrência nas regiões críticas, permitindo que somente um processo (ou tarefa) esteja executando sua regiâo crítica de cada vez. Essa idéia de exclusividade de acesso é denominada Exclusão Mútua [Axford, 1989] [Ben-Ari, 1990] [Shay, 1996] [Tanenbaum, 1992].

Diversos mecanismos de sincronização são discutidos na literatura. Nas próximas seções serão apresentados os mecanismos por troca de mensagens (utilizados em sistemas com memória distribuida), as soluçð̃es de hardware, semáforos e monitores (utilizados em sistemas com memória compartilhada).

\subsection{1 - Soluçóes de Hardware}

Uma solução de hardware bem simples para implementar o problema da exclusão mútua é fazer com que o processo que necessita entrar em sua região crítica desabilite todas as interrup̧̧ões externas e as reabilite quando deixar a região crítica. Como a mudança de estados dos processos só pode ser realizada através de interrup̧̧ões, após um processo desabilitar as interrup̧̧ões não será possível a troca de contexto até que elas sejam novamente habilitadas.

Essa solução traz uma série de inconvenientes, sendo 0 maior deles 0 comprometimento do sistema operacional se um processo desabilitar as interrup̧̧̃es e não reabilitá-las.

Alguns processadores possuem instruções atômicas que lêem uma variável e armazenam o seu conteúdo em uma outra área de memória atribuindo um novo valor a essa variável. Esse tipo de instrução também permite a criação de mecanismos de controle para o acesso da região crítica de um processo.

\subsection{2 - Semáforos}

As primeiras soluções por software apresentadas tinham a deficiência da espera ocupada. Na espera ocupada, quando um processo deseja entrar em sua região crítica ele fica 
perguntando para o sistema se o recurso já está liberado. Essa solução é inadequada, por que o processo não é bloqueado caso o recurso não esteja disponivel. Ele volta para a fila do processador aguardando por uma nova chance de executar podendo retornar ao processador antes que o recurso esteja disponivel. Ou seja, essa solução acaba provocando um alto custo no sistema como um todo.

O conceito de semáforo foi introduzido por Dijkstra citado em [Axford, 1989] [BenAri, 1990] [Tanenbaum, 1992], sendo uma solução mais simples.

Um semáforo é uma variável inteira, não negativa, que só pode ser manipulada pelas primitivas atômicas DOWN e UP (listagem 2.1). Essas primitivas funcionam como protocolos de entrada e saida no acesso à região crítica.

Listagem 2.1 - As primitivas DOWN e UP.

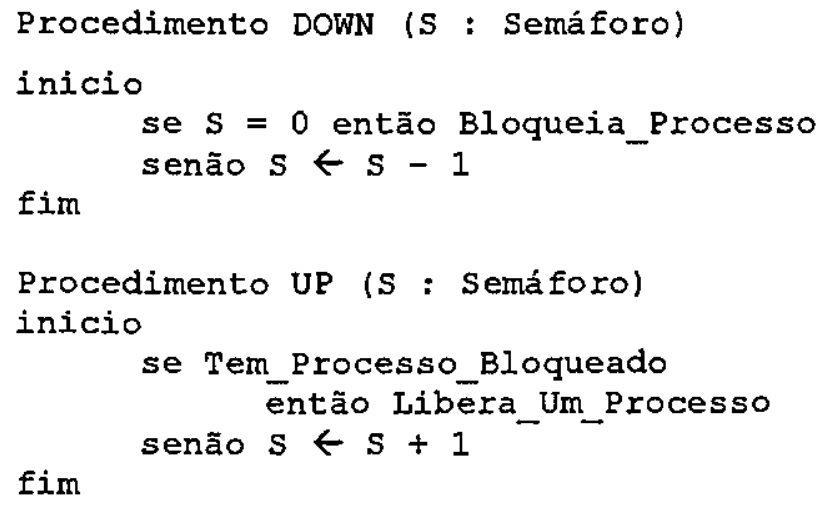

O funcionamento é bastante simples: se um processo deseja entrar em sua região crítica, ele realiza a operação DOWN em um semáforo criado para controlar o acesso àquele código. Se o semáforo estiver valendo 1, ele será decrementado e o processo continua sua execução, ou seja, entra na regiāo crítica. Se, ao contrário, o semáforo estiver valendo 0 , significa que já existe outro processo na região crítica e o processo que executou a operação DOWN é bloqueado. Quando um processo termina a execução da sua região crítica, a primitiva UP é executada, liberando a região crítica para outro processo. A primitiva UP verifica inicialmente se existe algum processo bloqueado. Se isto ocorre ela libera um deles, caso contrário incrementa o semáforo, sinalizando a disponibilidade da região crítica.

Semáforos que se aplicam ao problema da exclusão mútua são também chamados de mutex ou semáforos binários, pois assumem apenas os valores 0 e 1 . Porém, os semáforos podem ser utilizados para resolver uma série de outros problemas de sincronização entre processos, podendo assumir qualquer valor inteiro positivo. 


\subsection{2 - Monitores}

O uso de semáforos exige dos programadores bastante atenção, pois os problemas que podem resultar do uso incorreto dos semáforos podem ser dificeis de reproduzir devido ao não determinismo das tarefas. Dessa forma, foi proposto por Hoare, citado em [Ben-Ari, 1990], o mecanismo denominado monitor.

Um monitor é um conjunto de procedimentos, variáveis e estruturas de dados definido dentro de um módulo (semelhante a uma classe, da programação orientada ao objeto). A característica mais importante do monitor é a implementação automática da exclusão mútua, pois somente um processo pode estar executando os procedimentos do monitor em um determinado instante. Se um processo requisitar um procedimento do monitor, será verificado se já existe outro processo executando algum procedimento do monitor. Se isto ocorre o processo fica aguardando até o monitor estar disponivel novamente.

A principal diferença entre monitores e semáforos é que a exclusão mútua, no caso do monitor, é implementada automaticamente pelo compilador e não pelo programador, como é o caso dos semáforos.

\subsection{3 - Troca de Mensagens}

Em sistemas com memória distribuída, se torna inviável o uso de semáforos ou monitores, pois os processos que executam em processadores diferentes não possuem acesso ao mesmo endereçamento de dados. Nesse caso a única maneira de haver comunicação é através da troca de mensagens que é realizada pelas primitivas SEND e RECEIVE. Estas primitivas permitem realizar a sincronização e a comunicação entre os processos.

Existem alguns problemas que surgem em ambientes com troca de mensagens. $O$ principal deles é a perda de uma mensagem. Uma maneira de se garantir que as mensagens cheguem no destino, é forçando o processo receptor a enviar uma mensagem de confirmação para o emissor, que aguarda o recebimento dessa mensagem por um determinado tempo. Se isto não ocorrer, ele envia novamente a mensagem.

Existem, basicamente, duas formas de comunicação entre processos pela troca de mensagens: a comunicação síncrona e a comunicação assíncrona.

A comunicação síncrona acontece quando um processo que envia uma mensagem fica esperando até que o processo receptor leia a mensagem ou quando o processo receptor aguarda pelo envio de uma mensagem por algum processo. A comunicação assíncrona ocorre quando nenhum processo fica bloqueado, nem o processo emissor e nem o receptor. Nesse caso é necessário a utilização de buffers para o armazenamento temporário das mensagens. 
A vantagem da comunicação assíncrona é o maior paralelismo entre as tarefas. Já a comunicação síncrona permite a realização da sincronização entre os processos.

\section{5 - A Elaboração de Um Programa Paralelo}

Normalmente, existem vários caminhos para se resolver um problema através da programação seqüencial. O mesmo ocorre com a programação paralela. Infelizmente, nem sempre a lógica que foi expressa na resolução seqüencial de um problema funciona para a solução paralela. Às vezes, o resultado pode ser bem pior, não alcançando a eficiência almejada. Assim, muitas vezes é necessária uma abordagem do problema totalmente nova.

Para se resolver um problema utilizando programação paralela, pode-se utilizar as seguintes abordagens:

(1) Estudo das partes: essa abordagem parte do programa seqüencial e procura localizar as partes que podem ser realizadas em paralelo. A granulosidade depende da arquitetura e também da linguagem em que está sendo desenvolvido o programa. Mas pode ser explorado desde uma granulosidade fina até uma granulosidade média, de acordo com a característica do programa.

(2) Começar do zero: criar um novo algoritmo paralelo permite alcançar um melhor desempenho, pois é possivel desenvolver uma solução que explore com muito mais eficiência o paralelismo que a arquitetura a ser utilizada proporciona.

(3) Utilizar outro algoritmo paralelo: com essa abordagem, procura-se melhorar o desempenho do algoritmo paralelo existente. Essa solução exige um esforço menor do programador em identificar as partes paralelas e pode alcançar um bom desempenho.

Quando se projeta um algoritmo paralelo deve-se preocupar também com a quantidade de comunicação a ser utilizada pelo programa, pois isto aumenta o custo. É importante lembrar que dependendo da escolha adotada na concepção do algoritmo, pode-se desenvolver um programa muito pior em eficiência que a versão seqüencial ou outra versão paralela já existente.

\subsection{1 - O Ciclo de Vida de Um Programa Paralelo}

Um programa paralelo é, geralmente, bem mais complexo que um programa seqüencial. Portanto, na concepção de um programa paralelo é importante ter em mente os aspectos particulares da programação paralela, com vistas a não se criar um programa inadequado. 
As etapas na criação de um programa paralelo podem ser resumidas em:

(1) Criação do algoritmo paralelo: os aspectos que envolvem a criação de um algoritmo paralelo, dizem respeito a adaptação do problema a ser resolvido com a arquitetura que será usada para se implementar o algoritmo. Como já foi visto, as técnicas de comunicação e sincronismo estão diretamente relacionadas com a arquitetura e a granulosidade utilizadas. A abordagem também é importante, pois muitos algoritmos que necessitam de uma versão paralela já possuem uma versão seqüencial, o que pode ser um bom começo.

(2) Desenvolvimento do Programa: este é o momento de se escolher a linguagem a ser utilizada, como serão ativados os processos paralelos, e como serão realizadas às comunicações e os sincronismos entre as tarefas. Muitas linguagens já possuem paralelização automática, o que facilita a implementação. Essa etapa é o momento do usuário se familiarizar com a ferramenta que será adotada ou escolher aquela em que ele já possui experiência, se for possível utilizá-la.

(3) Mapeamento: o mapeamento é uma exclusividade dos programas paralelos. Após o desenvolvimento do programa é preciso definir em quais processadores as tarefas que compõem o programa serão executadas. Essa etapa é fundamental para se conseguir alcançar eficiência através de um bom balanceamento de carga.

(4) Teste e depuração: o ideal é que um programa seja testado com vários conjuntos de valores de entrada possíveis. Em grandes programas é dificil cobrir todas as possibilidades devido ao grande número de combinações que os valores de entrada podem assumir. Em programas paralelos, isto é ainda pior devido ao não determinismo das aplicações, como será visto no próximo capítulo. Existem vários tipos de testes [Pressman, 1992]:

- Teste de caixa preta: faz uma análise exclusiva dos resultados obtidos durante o teste.

- Teste de caixa branca: baseia-se em um exame detalhado dos procedimentos.

Para se testar programas paralelos é possivel usar uma das quatro estratégias abaixo:

- Teste de tarefas: os testes de caixa preta e caixa branca são projetados e executados para cada tarefa, ou seja, preocupa-se com a parte seqüencial do código. Esse tipo de teste pode revelar erros de lógica e erros funcionais, mas não revela erros de comunicação e sincronismo.

- Teste comportamental: através do uso de modelos do sistema, é possível simular o comportamento do programa paralelo. Esse modelo pode servir 
como a base para a definição dos casos de testes que serão realizados.

- Teste do relacionamento entre as tarefas: o objetivo desse tipo de teste é, após o isolamento dos testes anteriores, verificar a possível ocorrência de erros de comunicação e sincronismo.

- Teste do sistema: esse tipo de teste tenta verificar o conjunto hardware/software, pois estão fortemente casados na programação paralela.

A depuração é uma conseqüência de um teste bem sucedido, ou seja, quando um erro foi detectado. A depuração de programas paralelos será discutida em detalhes no próximo capítulo.

(5) Avaliação de desempenho: o objetivo da programação paralela é o aumento da velocidade do processamento. Pouco adianta um programa paralelo que executa sem erros, mas não consegue maior eficiência que o seu correspondente seqüencial. Para medir o ganho computacional de um programa paralelo em relação a um programa seqüencial são usados dois tipos de medidas: speedup e eficiência [Almasi e Gottlieb, 1994]. Speedup é o aumento da velocidade quando se executa um determinado programa em $p$ processadores em relação à execução desse mesmo processo em um processador. Eficiência relaciona o speedup com o número de processadores.

\section{6 - Plataformas de Portabilidade}

Existem várias ferramentas para o desenvolvimento de programas paralelos. 0 usuário, ao escolher a ferramenta, deve se pautar no tipo de aplicação e na arquitetura. Segundo Almasi [Almasi e Gottlieb, 1994], há três tipos de ferramentas: ambientes de paralelização automática, extensões paralelas para linguagens seriais $\mathrm{e}$ as linguagens concorrentes. Os compiladores capazes de gerar um código paralelo proporcionam uma codificação mais simples por parte do programador, mas nem sempre é possível alcançar um bom desempenho. As extensões das linguagens paralelas são bibliotecas contendo várias instruções para se realizar as operações paralelas, complementando as linguagens seriais já existentes. As linguagens especialmente criadas para a programação concorrente proporcionam um alto desempenho e a criação de códigos bem estruturados.

As plataformas de portabilidade ou bibliotecas para programação distribuída, que se enquadram nas extensões das linguagens paralelas, foram criadas inicialmente para facilitar 0 desenvolvimento de aplicações paralelas em máquinas com processamento maciçamente paralelo, mas passaram a dar suporte a programação paralela em sistemas distribuídos, 
expandindo a utilização dos sistemas distribuidos, que inicialmente objetivavam apenas o compartilhamento de recursos.

Essas bibliotecas fornecem uma extensão para algumas linguagens seqüenciais mais comuns (como C e Fortran), permitindo a elaboração de aplicações paralelas. Outra característica interessante, é que executando em um sistema distribuído, é possível utilizar computadores heterogêneos o que traz vantagens e desvantagens, conforme discussão a seguir. Essa caracteristica diferencia bastante um sistema distribuído de uma arquitetura maciçamente paralela, que possui todos os processadores homogêneos.

As maiores dificuldades encontradas em sistemas heterogêneos são:

- A diferença de potência computacional. Isto cria obstáculos a um balanceamento de carga eficiente, devido a dificuldade de se estabelecer comparações nos diversos tipos de processadores;

- Os formatos dos dados podem ser diferentes. Dados diferentes enviados de um computador para outro devem ser traduzidos para permitir a comunicação;

- Um sistema distribuído pode ser composto por máquinas de arquiteturas diferentes e muitas vezes é dificil prever todas as características das máquinas em que um programa executará, dificultando o alcance de um programa que explora todo o potencial das máquinas envolvidas no sistema.

Apesar disso, a computação paralela sobre sistemas distribuidos oferece grandes vantagens como:

- Menor custo, se comparado às arquiteturas paralelas;

- Escalabilidade;

- Possibilidade de se alcançar um alto desempenho, atribuindo para cada tipo de arquitetura a tarefa mais apropriada.

Um fator importante, particularmente para o enfoque deste trabalho, é que a depuração paralela em um ambiente de troca de mensagens tende a ser mais fácil que em uma linguagem explicitamente paralela.

Exemplos dessas bibliotecas são: P4, Parmacs, Express e principalmente PVM (Parallel Virtual Machine) e MPI (Message Passing Interface). 


\section{Capitulo 3 \\ Depuração de Programas Paralelos}

Construir um software que alcance um alto grau de confiabilidade é freqüentemente muito dificil, e para alcançar esse objetivo, o custo envolvido pode tornar-se muito alto. Vários sistemas existentes não são confiáveis, mesmo assim, são muito utilizados [Axford, 1986]. Nota-se que entre as diversas razões que contribuem para essa situação, uma decisiva é que a alta confiabilidade não é o objeto de interesse principal, sendo colocada em segundo plano quando se defronta o custo adicional que as fases de testes e depuração acrescentam. É curioso notar, entretanto, que sistemas não confiáveis podem multiplicar o custo gasto para o seu desenvolvimento de forma inaceitável, tomando os usuários menos tolerantes a baixa confiabilidade com o passar do tempo.

Os primeiros computadores foram usados em pesquisas científicas e trabalhos específicos, sendo comum o desenvolvimento de software de certa forma especulativa e com baixa confiabilidade. Não existiam técnicas claramente confiáveis e o desenvolvimento de um software era uma tarefa artesanal. As máquinas eram lentas e caras e, normalmente, o desempenho era o foco principal.

Nos dias atuais, a situação tem mudado radicalmente. O hardware apresenta um custo mais acessível e um desempenho superior e o software adquiriu uma função crucial em várias aplicações com muita demanda de tempo. Essa atenção que vem sendo dada ao software é essencial e aumenta a preocupação que se deve ter na criação de sistemas que não sejam apenas eficientes, mas que também apresentem um alto grau de confiabilidade.

Essa confiabilidade só poderá ser atingida se forem observados dois objetivos básicos:

(1) Melhorar o nível dos procedimentos envolvidos nas etapas de desenvolvimento do software; 
(2) Aperfeiçoar as técnicas para se testar e corrigir programas, fortalecendo o refinamento de possiveis falhas.

Em princípio, esses objetivos têm sido alcançados quando se trata de programas seqüenciais. Entretanto, um aumento considerável na aplicação dos programas paralelos, devido ao crescimento dos ambientes paralelos e principalmente na popularização do uso das redes de computadores e dos sistemas distribuídos, vem sendo observado. Considerando ainda a grande complexidade desses programas, surge a necessidade de se criar programas para a depuração de códigos paralelos mais eficientes que os programas responsáveis na depuração dos códigos seqüenciais [McDowell e Helmbold, 1989]. Têm surgido várias técnicas para se alcançar o primeiro objetivo (desenvolvimento de software), mas as pesquisas sobre as técnicas de depuração ainda são bastante teóricas. Devido ao fato de existirem vários ambientes e linguagens para o desenvolvimento de sistemas paralelos, algumas das poucas ferramentas de depuração que existem acabam caindo no desuso, pois algumas linguagens, ou mesmo plataformas, com o passar do tempo se tornam pouco utilizadas.

É curioso notar que a depuração tem sido considerada mais uma arte do que uma ciência [Cheung et al., 1990]. Muitas vezes a depuração é um processo intuitivo. O problema é que nem sempre é possível garantir que a intuição está correta, assim, muitos desenvolvedores encontram grande dificuldade para localizar erros em seus sistemas. Isto é provocado por várias situações diferentes [Pressman, 1992]. Em muitas ocasiões os sintomas surgem em um determinado ponto da execução do programa, entretanto a causa pode se localizar em outra parte, o que dificulta a sua correção. Outra situação bastante encontrada é que alguns erros são causados por problemas de hardware, podendo os sintomas desaparecer.

Quando um sistema é extremamente grande, reproduzir as entradas que provocaram a execução errada é uma tarefa quase impossível. Essa situação chama atenção, pois, sistemas paralelos tendem a ser enormes, e se já é dificil reproduzir a execução em um ambiente seqüencial, em um ambiente paralelo a situação torna-se ainda mais complexa, devido ao não determinismo das tarefas paralelas.

Em adição, é interessante comentar sobre os aspectos psicológicos relacionados com a busca de erros nos sistemas. Muitos programadores encontram dificuldade em admitir que seus programas possam estar errados e que necessitam de depuração. Quanto a isso Shneiderman, citado em [Pressman, 1992] afirma:

“A depuração é uma das partes mais frustrantes da programação. Ela tem elementos de solução de problemas ou de complicações, combinados com o aborrecido reconhecimento de que se cometeu um erro. A elevada ansiedade e a pouca disposição 
para aceitar a possibilidade de erros aumenta a dificuldade da tarefa. Felizmente, vem um grande suspiro de alivio e uma dimimuição da tensão quando o bug é por fim... corrigido".

É importante salientar a necessidade de se evitar os erros durante o desenvolvimento do programa, pois muitos programadores repetem os mesmos erros em sistemas diferentes. Geralmente, isto ocorre devido à falta de uma metodologia adequada durante o desenvolvimento e, também, durante a depuração. Os programadores realizam várias tentativas até conseguir que o programa funcione conforme as especificações, e quando isto ocorre, eles não conseguem perceber o que realmente estava provocando a falha. Por isso, é importante que as ferramentas de depuração não sejam somente "detetives" na busca de "culpados", mas que assumam também a função de "professores", alertando aos usuários quanto aos motivos que geraram os erros. Essa abordagem permite a aquisição de conhecimento pelo desenvolvedor durante a etapa de depuração, já que uma forma de também melhorar o processo de desenvolvimento é aumentar o senso crítico do desenvolvedor, bem como seus conhecimentos na área.

\section{1 - Características Especiais na Depuração dos Programas Paralelos}

A depuraçăo de programas paralelos, em sua essência, é similar à depuração dos programas seqüenciais, ou seja, é a busca por problemas que provocam um comportamento não esperado no programa. Entretanto, a programação paralela tende a ser muito mais complexa, e muitos usuários, principalmente principiantes, encontram grande dificuldade em se adaptar aos conceitos inerentes a esse tipo de programação.

A adoção de linguagens concorrentes no desenvolvimento de software e as dificuldades desse tipo de programação, têm acentuado a necessidade de se criar um conjunto integrado de ferramentas para auxiliar neste desenvolvimento [Baiardi et al., 1986].

Pode-se observar várias diferenças entre programas paralelos e programas seqüenciais. A maior delas é o não determinismo global. Em programas seqüenciais, quando é selecionado um conjunto de valores de entrada, o fluxo de controle dos programas sempre segue por um mesmo caminho, dessa forma, o processamento sempre provoca resultados iguais. Entretanto, quando se trata de programas paralelos, isto nem sempre é verdadeiro, pois a necessidade de sincronização e comunicação das várias tarefas que compõem o programa e o tempo gasto por cada tarefa, pode resultar em comportamentos diferentes, se o programa não for bem codificado. 
É possivel agrupar em 4 categorias as diferenças que dificultam a depuração em programas paralelos e torna esse tipo de programaçăo uma tarefa trabalhosa:

(1) Tipo do processo: as características de cada processo interferem diretamente na velocidade em que ele é processado. Um processo pode necessitar somente da utilização da CPU, como por exemplo, os programas que realizam muitas operações numéricas. Esse tipo de processo é chamado de CPU-bound e o seu tempo de execuçăo depende exclusivamente da velocidade do processador e o tempo de espera na fila. Outro tipo de processo é o denominado $1 / O$-bound. Essa classe de processos possui a característica de realizar muito acesso aos mecanismos de armazenamento de informação como acontece nos sistemas de gerência de banco de dados. Os processos podem ainda conter ambas as características, o que é muito comum [Tanenbaum, 1992]. Essas diferenças não permitem afirmar com precisão a ordem em que os eventos ocorrerão.

(2) Vários processadores: o tempo gasto para a execução de cada tarefa pode resultar em comportamento diferente no sistema como um todo. Isto é, o tempo total de cada tarefa, depende da velocidade do processador, o seu tempo de espera na fila e da quantidade de processadores no ambiente paralelo, pois um maior número de processadores tende a diminuir o tamanho da fila de espera de cada tarefa. Como cada processo que compõe um programa paralelo pode executar em diferentes processadores fisicos, toma-se ainda mais dificil descobrir o comportamento errôneo do programa e a gerência dos processos de depuração.

(3) Tempo de comunicação: os processadores nos quais um programa paralelo executa, podem estar geograficamente dispersos, como é o caso dós sistemas distribuídos. Isto pode provocar atrasos na comunicação tornando algumas operações de depuração impraticáveis. Normalmente já existe um retardo entre a ocorrência de um erro e a sua descoberta, mesmo nos programas seqüenciais. $O$ grande problema nos programas paralelos é que um erro pode se propagar bastante, até que seja detectado [Cheung et al., 1990].

(4) Tamanho do Sistema: os sistemas paralelos tendem a ser grandes, ou seja, possuírem um número de processos elevado, além de possuírem muito mais recursos envolvidos. Assim, quanto maior o sistema, mais dificil é sua depuração, pois é dificil realizar testes que possam gerar todas os caminhos possíveis em um sistema.

(5) Probe Effect. um outro ponto que deve ser considerado na depuração de 
programas paralelos é a interferência do depurador nos resultados do programa. Quando a depuração interfere na execução de um determinado processo, o comportamento de outros processos poderá também ser influenciado. Dessa forma, o programa para depuração deverá oferecer mecanismos de análise sem afetar o comportamento do programa, ou seja, a presença do depurador deverá ser transparente ao funcionamento do programa [Baiardi et al., 1986]. Nos programas paralelos, esse esforço em obter mais informações do comportamento de um programa, em muitas situações acaba provocando uma interferência perniciosa, ou seja, o programa de depuração interfere na reprodução do funcionamento "natural" do programa que está sendo depurado. Essa situação é conhecida como probe effect [Damitio e Turner, 1995].

(6) Baixa Visibilidade: é um termo usado por muitos autores. Quando o programa é executado sobre um sistema distribuído, a ordem de execução das instruções pertencentes aos diferentes processos do programa não pode ser deduzida. Esse fator é fundamental, afinal o grande crescimento da aplicação de programas paralelos vem, principalmente, do aumento da aplicabilidade dos sistemas distribuídos. A sincronização nos sistemas distribuídos é bastante complexa devido à dificuldade de padronizar o relógio das diversas estações que o compõem.

Quando os processos paralelos estão executando com as mesmas entradas, seus resultados podem ser radicalmente diferentes. Essas diferenças são causadas pelas condições de corrida, que ocorrem quando duas atividades estão progredindo em paralelo. Por exemplo, um processo deve escrever em uma posição da memória enquanto o segundo processo deverá ler a mesma célula. $O$ segundo processo poderá ler o valor novo ou o antigo, dependendo da ordem de acesso, que pode ser alterada devido à velocidade de execução de cada processo, que como já foi discutido depende do processador, tamanho da fila de processos, tipo de processos, etc.

É interessante notar que se a probabilidade de um mau funcionamento ocorrer for muito pequena, a situação de erro poderá nunca ser recriada.

Essas diferenças tornam a depuração dos programas paralelos uma tarefa extremamente delicada e uma área de pesquisa fascinante.

\section{2 - Abordagens Clássicas na Depuração de Software}

A abordagem clássica para se depurar um programa seqüencial envolve várias paradas durante a execução - breakpoints, com o objetivo de examinar o estado das variáveis ou o 
fluxo do programa, muitas vezes, sendo necessária uma nova execução de um determinado trecho. Esse estilo de depuração é chamado de depuração cíclica. Em cada parada é possivel examinar ou mesmo modificar, de forma interativa, parte dos processos que estão sendo examinados. Infelizmente, programas paralelos nem sempre podem ser reproduzidos corretamente, pois é muito dificil definir paradas em termos da precisão dos estados globais. Essa abordagem pressupõe, ainda, um bom conhecimento de todo o sistema para saber os melhores pontos de parada do programa.

A abordagem da depuração ciclica freqüentemente falha para programas paralelos porque essas situações de indeterminação não podem ser previstas quando o programa é novamente executado. Em outras palavras, a recriação das circunstâncias que levaram ao erro, pode nunca ser conseguida. Quando o programa é testado com uma entrada, uma simples execução é insuficiente para determinar a exatidão do programa para essa entrada. Durante a depuração de uma execução errônea desse programa, nāo há garantia de que esta execução será repetida quando o programa for executado novamente, repetindo-se os dados de entrada. Isto é um problema crítico, porque freqüentemente é necessário repetir uma execução errônea da mesma forma para coletar informações adicionais para depuração. Durante uma execução, é dificil salvar todas as informações de depuração que podem ser necessárias para localizar a causa do erro.

Outra abordagem, também muito comum, é a depuração de saída. É a abordagem mais primitiva e, provavelmente, todo o programador já a utilizou. Essa abordagem consiste na apresentação dos estados das variáveis durante a execução do programa. A depuração de saída requer a alteração do programa, o que não ocorre na abordagem de breakpoints, e pode provocar o indesejado probe effect. Um exemplo fácil de perceber esse efeito é quando dois processos entram em uma situação de um abraço fatal - deadlock -, que será visto no próximo capítulo por se tratar de um problema clássico que deve ser observado por um depurador. Nessa abordagem, durante a busca do erro deve ser acrescentada alguma linha de código em um dos processos, com o objetivo de se obter informaçoes desse processo ou de apresentar o estado de uma variável. Esse simples comando pode ser suficiente para sincronizar os dois processos, ou seja, atrasar o processo modificado, fazendo com que o outro processo saia da sua região crítica sem apresentar o problema, criando um comportamento errôneo com relação a sua codificação.

Muitos depuradores apresentam a técnica de tracing que é uma junção das duas abordagens anteriores. $\mathrm{O}$ depurador utiliza de algum sinal facilmente fornecido pelo sistema operacional, compilador ou ambiente de programação para apresentar informações 
selecionadas e que pode ser habilitado ou desabilitado. Mas essa abordagem, quando trabalhando sobre um sistema distribuido, enfrenta os problemas da dificuldade de se ter um estado global.

\section{3 - Classificação dos Depuradores para Programas Paralelos}

Alguns pesquisadores distinguem entre monitoração e depuração tradicional [McDowell e Helmbold, 1989]. Monitoração é o processo de reunir informações sobre um programa em execução. Depuração é o processo de localização, análise, correção e eliminação de falhas, onde a falha é definida como sendo uma condição acidental causadora de um erro em um programa que executou alguma de suas funções [Stewart e Gentleman, 1997]. Apesar dessa diferenciação, um processo monitor é freqüentemente um processo que tem como objetivo localizar procedimentos incorretos. Devido ao auxílio que pode ser conseguido com a utilização de um processo monitor, o monitor é visto como uma ferramenta de depuração.

As técnicas de depuração de programas concorrentes têm sido organizadas em quatro grupos:

(1) Técnica de depuração tradicional, que pode ser aplicada com algum sucesso em programas paralelos.

(2) Técnica de depuração baseada em eventos, que encara a execução de um programa paralelo como uma seqüência (ou várias sequêencias paralelas) de eventos.

(3) Técnica da visualização do fluxo de controle e distribuição de dados associados com programas paralelos.

(4) Técnica de análise estática baseada na análise do fluxo de dados dos programas paralelos.

A maioria dos programas de depuração atuais se baseia nas técnicas de depuração tradicional e nas técnicas baseadas em eventos, mas existem programas que possuem ambas as caracteristicas.

Um programa de depuração de programas paralelos com base nas técnicas tradicionais é geralmente, o mais fácil de ser implementado e, portanto, o que proporciona uma solução mais rápida. Entretanto, a grande desvantagem desse tipo de depurador é que em programas com muitos processos concorrentes se torna muito dificil identificar e compreender o que realmente está acontecendo no nivel dos processos. Essa técnica de depuração funciona bem na observação do comportamento do programa em nível de instrução ou em nivel de procedimento. Isto ocorre porque, geralmente, um depurador paralelo tradicional é formado 
por um conjunto de depuradores seqüenciais, sendo normalmente, um para cada tarefa. Outro limitador para essa técnica é a possibilidade de acontecer o probe effect, devido a necessidade de interação do programa de depuração com o sistema examinado.

Os depuradores baseados em eventos proporcionam uma melhor abstração que os depuradores tradicionais. Também podem provocar probe effect, pois forçam uma execução deterministica dos programas paralelos. Enquanto alguns sistemas exibem apenas os eventos ocorridos, outros registram um histórico de eventos, contendo todos os eventos gerados pelo programa. Esse histórico pode ser examinado pelo usuário após o término do programa. $\mathrm{O}$ histórico dos eventos pode também ser utilizado para guiar uma nova execução do programa, permitindo a reprodução da computação errônea. Mas, como sempre, nem tudo são vantagens, se o programa for muito grande pode ser impossível armazenar tanta informação.

Diversos sistemas para depuração permitem que um programa seja executado novamente (replay) sob o controle de um histórico de eventos. O replay não é uma simulação, mas a execução com as mesmas entradas que foram armazenadas no histórico, com um mecanismo que força a ordem dos eventos na execução original [Cheung et al., 1990]. Se o histórico refletir corretamente a comunicação ocorrida entre os processos durante a execução original, então a nova execução produzirá os mesmos resultados. Outra vantagem é que se o histórico é suficientemente completo, um único processo pode ser depurado isoladamente com o histórico fornecendo a comunicação necessária.

Um ponto importante a ser considerado é que a sincronização envolvida durante a nova execução pode diminuir o desempenho do programa paralelo. Em sistemas de tempo real, essa reexecução proporciona diversos problemas. Além da comunicação entre processos a entrada e saída e as interrup̧ões devem também ser registradas, uma vez que sistemas de tempo real geralmente dependem muito do tempo, é importante simular o tempo durante a nova execução, o que requer mais eventos no histórico. Além disso, um problema que já foi apresentado é a necessidade de tornar o depurador transparente, e nem sempre é fácil fazer com que o processo monitor, responsável pela manutenção do histórico de eventos, não interfira na sincronização entre os processos da tarefa examinada.

Os depuradores baseados na técnica de análise estática não apresentam a etapa de teste, pois não necessitam da execução do programa. Geralmente a análise é feita checando as falhas estruturais ao invés de se verificar as falhas funcionais permitindo a eliminação de erros antes que eles ocorram.

As ferramentas de análise estática evitam o probe effect, porém não executam programas. Possuem o potencial para identificar grandes classes de erros dificeis de encontrar 
em aiguns programas usando as técnicas dinâmicas. Essas ferramentas permitem localizar tipos básicos de erros: aqueles causados por problemas de sincronização e os erros nas operações com dados. Os primeiros se referem, por exemplo, aos problemas de deadlock e espera infinita. Já os erros causados nas operações com dados, dizem respeito aos erros usualmente seqüenciais como leitura de variáveis não inicializadas e erros no acesso paralelo dos dados compartilhados.

O problema básico com a maioria dos algoritmos para a análise estática é que geralmente, no pior caso, a complexidade do algoritmo é freqüentemente exponencial.

É possivel ainda combinar as técnicas de análise estática com a depuração dinâmica. Uma forma de se combinar estas técnicas é partir da análise estática para projetar os casos de teste para uso em conjunto com um depurador dinâmico. Dessa forma, as partes do programa que pela análise estática se mostrarem corretas, não precisarão passar pela monitoração dinâmica, o que reduz o overhead associado com a depuração. $O$ contrário também é possivel, ou seja, a informação obtida a partir da monitoração dinâmica poderia ser usada para dirigir uma análise estática parcial, pois a análise estática completa produz muitos estados. Essa união pode apresentar as melhores soluções e diversos pesquisadores têm apresentado técnicas que combinam o uso da análise estática e da análise dinâmica [McDowell e Helmbold, 1989].

\section{4 - Apresentação dos Resultados}

Nos programas seqüenciais a apresentação dos resultados durante ou após, a depuração é uma tarefa razoavelmente simples. As informações podem ser apresentadas como um único texto seqüencial, já que apresenta a ordem em que foram executadas. Outro detalhe importante é o fato, dos dados estarem localizados em um mesmo local, podendo ser acessados facilmente quando necessário.

Os programas paralelos possuem uma abordagem bastante diferente. Eles possuem diversos processos executando concorrentemente e os dados se encontram logicamente e, as vezes, fisicamente separados.

Um importante objetivo no estudo da depuração de programas paralelos está em se encontrar a forma de apresentar os dados distribuídos sem causar probe effect, e de uma forma que possibilite aos usuários a sua compreensão.

Existem algumas técnicas de apresentação das informações resultantes da depuração paraiela [McDowell e Helmbold, 1989], entre elas:

(1) Apresentação dos dados de maneira textual, podendo envolver cor com o objetivo 
de apresentar o fluxo de controle da informação. É a técnica mais comum e presente nos sistemas atuais. É a forma utilizada pelos depuradores paralelos tradicionais. Em sistemas baseados em eventos, a apresentação seqüencial de um processo específico pode ser útil. Em sistemas baseados em objetos, uma lista seqüencial dos objetos é criada na ordem em que os mesmos são acessados.

(2) Diagramas de Processo x Tempo que apresentam a execução do programa paralelo em saidas bidimensionais. Esses tipos de diagramas são importantes para a visualização das atividades dos sistemas paralelos. Para a maioria dos sistemas, um relógio global é necessário. Sua limitação está no número de processos que podem exceder o tamanho da tela, mas isto pode ser resolvido através da filtragem ou ocultamento de processos.

(3) Uma alternativa para o diagrama anterior é criar uma animação da execução do programa, em que ambas as dimensões são espaciais, mostrando imagens especificas do programa em intervalos de tempo. Essa apresentação consiste em colocar cada processo em um ponto diferente do vídeo, de forma que todo o vídeo apresente o sistema em um único instante de tempo. As alterações de eventos são sucessivamente mostradas no vídeo, gerando uma espécie de animação. A posição dos processos pode ser arbitrária, sob controle do usuário ou em função da estrutura do programa. Alguns sistemas permitem controlar o tempo de apresentação de cada imagem e apresentar o conteúdo de mensagens trocadas entre os processos.

(4) Uma pequena variação seria a utilização de várias janelas, permitindo várias imagens simultâneas do programa sendo depurado. Esse tipo de apresentação envolve a criação de uma janela para cada processo.

Nenhuma dessas técnicas, utilizada de forma isolada, é suficiente para detectar todos os erros que podem surgir em programas paralelos. Por exemplo, a animação permite uma boa visão dos estados do sistema em um determinado instante. Para um único instante de tempo, mais informações podem ser apresentadas simultaneamente. Também permite a observação de padrões de comportamento. Mas, não mostra claramente os padrões de comportamento que ocorrem em função do tempo. Em contrapartida, o diagrama processo $\mathrm{X}$ tempo apresenta padrões de comportamento em função do tempo, e torna-se útil para descobrir problemas relacionados a desempenho. A principal desvantagem dessa abordagem é que poucas informações podem ser mostradas para cada processo em um determinado instante de tempo. 


\section{5 - Consideraçōes Sobre os Sistemas Distribuídos}

Até esse momento foi abordado o problema da depuração de programas paralelos considerando sistemas distribuídos e arquiteturas paralelas quase que sem distinção, porém existem algumas considerações que devem ser levadas em conta quando um programa paralelo está executando em um ambiente distribuído.

Nos sistemas distribuídos encontra-se o conceito de estado global. A sincronização global do clock é um problema de pesquisa clássica em sistemas distribuídos. Sem uma sincronização global do clock, pode ser dificil determinar com precisão a ordem dos eventos que estão ocorrendo em processadores diferentes. Se cada computador executa em um clock diferente, como saber exatamente qual evento ocorreu primeiro? Em um sistema centralizado já existe o conceito de consistência interna, que representa a ordem cronológica em que dois eventos ocorrem, mesmo que o clock da máquina não represente o tempo real, todos os processos dessa máquina possuem o mesmo clock como referência [Tanenbaum, 1992]. Em contrapartida, os processos que executam em sistemas distribuídos possuem características próprias, pois as informações que são relevantes estão espalhadas em diversas máquinas e o processo necessita tomar decisões observando as informações locais. A necessidade de manter essas informaçōes trafegando pela rede de comunicação é a maior causa dos problemas de deadlock nos sistemas paralelos que executam sob os sistemas distribuídos. Dois processos não precisam concordar com o tempo atual, mas devem saber exatamente a ordem em que os eventos ocorrem.

Assim, alguns dos problemas que surgem nos programas paralelos estão relacionados com a necessidade de compartilhamento de recursos e informações. Um processo, mesmo que esteja executando em paralelo com outros processos, se não necessitar de recursos comuns ou mesmo de trocar informações, não apresentará os erros que estão sendo abordados nesse trabalho. Os erros que eventualmente ocorram diz respeito, única e exclusivamente, aos problemas de ordem seqüencial, como, por exemplo, a falta de inicialização de variáveis ou fallhas no fluxo do processo, situações que são resolvidas com a utilização de depuradores seqüenciais.

Em sistemas com memória centralizada o estudo de possíveis situações de conflito se baseia na análise de técnicas de sincronização como semáforos e monitores. Nos sistemas distribuídos, onde os processos que executam em máquinas diferentes não têm acesso às memórias dos demais processos, as comunicações e os sincronismos são realizados através de primitivas de envio e recebimento de mensagens, isto torna a busca de erros uma tarefa muito mais trabalhosa. 
O objetivo de se analisar os problemas que surgem em um sistema distribuído, vem do fato de que o foco principal de um depurador paralelo é a interação entre os processos e não sua lógica interna. Isto porque os problemas internos podem ser removidos através de depuradores seqüenciais [Cheung et al., 1990].

No capítulo sobre deadlock serão apresentadas algumas soluções para alguns desses problemas encontrados nos sistemas distribuídos. 


\section{Capítulo 4 Deadlock}

Quando os sistemas eram não preemptivos um processo começava a sua execução e só era retirado da memória quando terminava ou quando o seu tempo de execução excedia muito a expectativa de término do sistema operacional. Dessa forma todos os recursos disponiveis na arquitetura estavam inteiramente disponiveis para o processo que estava executando. Isto não causava nenhum conflito e o gerenciamento desses recursos era mais simples.

A possibilidade de várias tarefas estarem ativas em um determinado momento só foi possivel com o advento dos sistemas de tempo compartilhado, onde foi introduzido o conceito de tempo compartilhado para simular o paralelismo entre as tarefas. Nesse tipo de sistema os processos não executam indefinidamente até terminarem. O sistema implementa a preempção e interrompe um processo que está executando após uma pequena fatia de tempo, salva sua parte volátil e transfere o fluxo para outro processo, após recuperar a parte volátil pertencente ao novo processo. E esse processo, por sua vez, também executa por uma pequena fatia de tempo. Esse rodízio segue indefinidamente, enquanto existe processo executando, criando um paralelismo virtual.

Com o compartilhamento do tempo da CPU e a possibilidade de cada processo mudar de estado a CPU passou a ser melhor utilizada, pois enquanto um processo aguarda o resultado da busca de dados em algum dispositivo de armazenamento, como o disco rígido, o sistema operacional pode escalonar um novo processo.

Como existem vários processos executando existe a possibilidade de vários deles necessitar dos recursos disponiveis no ambiente. $\mathrm{E}$ o que pode acontecer quando a quantidade de recursos não é suficiente para todos os processos? Se cada processo só utilizar um recurso de cada vez, basta criar um protocolo de acesso ao recurso, bloqueando o próximo processo 
que necessitar do recurso antes desse estar desocupado. Mas essa situação nem sempre é verdadeira, pois muitos processos precisam ter acesso simultâneo e exclusivo a vários recursos. E essa necessidade de utilização de vários recursos pode provocar algumas anomalias, sendo a principal delas o deadlock, que é uma situação em que um processo aguarda por um recurso que nunca estará disponível.

Como exemplo, considere a situação em que um processo $P I$ solicita e consegue permissão para usar um recurso $R 1$, e um processo $P 2$ solicita, por sua vez o recurso $R 2$, também conseguindo permissão para utilizá-lo. Se o processo $P 2$ requisitar o recurso $R I$, sem liberar o recurso $R 2$, e considerando que o processo $P I$ ainda não terminou de utilizá-lo, o processo $P 2$ será bloqueado. Se após esse bloqueio o processo $P 1$, também necessitar do recurso $R 2$, estará caracterizada a ocorrência de um deadlock. Nessa situação é fácil perceber a anomalia, pois estão envolvidos apenas dois processos. Mas o problema do deadlock pode envolver vários processos.

Deadlock pode ser formalmente definido como [Tanenbaum, 1992]:

"Um conjunto de processos, esperando por eventos que somente outro processo pertencente ao mesmo conjunto poderá fazer acontecer".

Aqui, recurso é algo que só pode ser usado por um único processo em um determinado instante de tempo. Pode ser um dispositivo de hardware, como, por exemplo, a impressora, ou uma informação, como um registro em uma base de dados.

\section{1 - Deadlock e Depuração de Programas Paralelos}

Deadlock é um problema clássico no estudo dos sistemas operacionais, sendo uma situação de dificil correção [Axford, 1986]. A dificuldade em torno dos deadlocks é que eles possuem a propriedade de serem estáveis, ou seja, uma vez que ocorram, persistirão até que seja detectado e quebrado. Os processos envolvidos não poderão dar continuidade em sua execução até que algum processo externo quebre o deadlock, liberando algum recurso [Craveiro, 1998]. Fica a cargo do projetista do sistema decidir por qual técnica escolher. Geralmente, a escolha recai entre algoritmos de prevenção ou algoritmos de detecção e correção, ou ainda em não fazer absolutamente nada (o famoso algoritmo do Avestruz: enfiar a cabeça na terra e fingir que nada está acontecendo). Essas abordagens apresentam vantagens e desvantagens e são adequadas a sistemas com características específicas.

A atenção que se dá ao problema do deadlock nesse trabalho vem do fato de que são considerados programas que possuem vários processos executando paralela ou concorrentemente, disputando por recursos comuns. 
A maioria dos artigos e estudos feitos sobre deadlock trata do assunto em ambiente de sistema e não analisam a possibilidade de ocorrer deadlock entre os processos que compõe um programa paralelo. O deadlock que ocorre em nível de sistema será definido como deadlock externo. Esse tipo de deadlock é dificil de resolver, porque o controle pertence ao sistema operacional, que se não possuir recursos para resolvê-lo, nada poderá ser feito. A aplicação do usuário não pode auxiliar na solução do deadlock externo, pois não tem conhecimento de quais processos estão executando e que recursos eles estão utilizando. Essa tarefa é de responsabilidade do sistema operacional.

O deadlock que ocorre em nível de programa do usuário, provocado pelos próprios processos que compõe a aplicação será definido como deadlock interno. $O$ estudo desse tipo de ocorrência possibilita corrigir erros de sincronização e de requisição de recursos, que podem ser controlados pelo próprio fluxo do programa, não havendo necessidade do envolvimento do sistema operacional.

\section{2 - Condiçōes Para a Ocorrência de Deadlocks}

É claro que a ocorrência de deadlock é uma situação indesejada, pois quando o deadlock ocorre os processos não terminam sua execução e os recursos do sistema ficam presos, sem serem utilizados.

Como identificar, então, se um programa com diversas tarefas, ou mesmo um conjunto de processos independentes competindo pela utilização dos recursos do sistema, poderão causar deadlock? Quatro condições são necessárias para se caracterizar uma situação de deadlock [Tanenbaum, 1992], [Shay, 1996] e [Craveiro, 1998]:

(1) Condição da Exclusão Mútua: cada recurso só poderá estar sendo utilizado por um processo de cada vez, ou estar disponível.

(2) Condição de Posse e de Espera: um processo detendo um recurso aguarda por outro recurso.

(3) Condição de Não Preempção: um recurso não pode ser retirado de um processo, sem que esse libere o mesmo voluntariamente.

(4) Condição de Espera Circular: deve existir um conjunto de processos bloqueados, onde cada um dos processos pertencentes a esse conjunto, espera por um recurso alocado para um processo do próprio conjunto. Essa situação foi ilustrada na apresentação do capitulo.

Diante dessas situações, a solução encontrada por diversos projetistas é a tentativa de prevenir pelo menos a ocorrência de uma dessas condições, já que para a ocorrência de 
deadlock é preciso que todas as quatro condições estejam presentes [Tanenbaum, 1992].

A prevenção dessas condições acarreta um alto custo para o sistema e evitar algumas dessas situações pode acarretar um problema muito maior que o próprio deadlock. Por exemplo, a eliminação da exclusão mútua, certamente retira toda a possibilidade de ocorrer deadlock, porém, no capítulo anterior foram apresentadas as anomalias que podem ocorrer quando um recurso não preemptivo está sendo utilizado concorrentemente por vários processos [Brawer, 1989].

Outra situação complexa é a tentativa de se evitar a condição de posse e espera. Uma primeira forma de se evitar esta condição é retirar os recursos já alocados a um processo quando este solicitar novos recursos, o que não faz sentido algum, já que um recurso não preemptivo não pode ser acessado concorrentemente. Uma segunda forma de se evitar a posse e espera é fazer com que o processo solicite todos seus recursos de uma vez só, antes de ser executado. Esta opção é totalmente inadequada, pois se um processo utilizar um arquivo em disco durante uma hora e depois imprimi-lo, a impressora será alocada a este processo juntamente com o disco, ficando uma hora sem utilização. Outro problema relacionado a solicitação de todos os recursos de uma só vez é o caso de um processo necessitar de muitos recursos, esses recursos podem não estar disponiveis simultaneamente sendo que o processo ficará esperando por uma ação que nunca acontecerá.

A remoção da não preempção pode ser conseguida testando o estado dos recursos solicitados. Se eles estão livres, são alocados. Se eles estão ocupados, então todos os recursos que o processo já havia alocado são liberados, e retomam para a lista dos recursos disponíveis. 0 processo voltará a executar quando conseguir alocar seus velhos recursos juntamente com o novo recurso sendo solicitado. É claro que esse algoritmo só pode ser aplicado em recursos cujo estado pode ser facilmente salvo e reposto mais tarde.

A espera circular é a última condição e também não é fácil de ser evitada. Isto será possivel se os processos não puderem pedir recursos em tempos diferentes, mas como discutido nos parágrafos anteriores esse método é inviável. Outra forma de evitar é fazer com que cada processo use um recurso de cada vez. Também já foi comentada a impossibilidade dessa abordagem.

Pode-se observar que a prevenção de deadlock é dificil, devido aos novos problemas que surgem quando utilizam-se os métodos para amenizar o problema.

\section{3 - Detecção de Deadlocks}

A prevenção de deadlocks é uma abordagem utilizada em ambiente de sistema 
operacional visando os deadlocks extemos. As técnicas de detecção se aplicam ao problema do deadlock interno. Dessa forma, as técnicas relacionadas a detecção de deadlock é de grande importância para este trabalho.

A abordagem de deteç̧ão mais simples ocorre quando no sistema só existe um recurso de cada tipo, como uma impressora, uma unidade de fita, uma plotter, etc. Para esse tipo de análise a criação de um grafo dirigido (dígrafo) de recursos, como ilustrado na figura 4.2, é a maneira mais fácil de se detectar a ocorrência de deadlock.

Em um dígrafo como os das figuras 4.1, os nós representam os processos (círculos) e os recursos (quadrados) envolvidos e os arcos representam a dependência de cada um, como pode ser visto na figura 4.1. Na figura 4.1(a) encontra-se a representação de um arco partindo de um nó quadrado (recurso) em direção a um nó em formato de círculo (processo) representando um processo de posse de um recurso. A figura 4.1(b) apresenta um processo aguardando por um recurso não disponível. Observando a figura 4.1(c) verifica-se a ocorrência de um cíclo no dígrafo, demonstrando a ocorrência de deadlock.

Figura 4.1 - Grafos de alocaçäo de recursos [Tanenbaum, 1992].

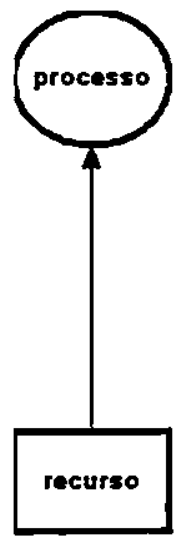

(a)

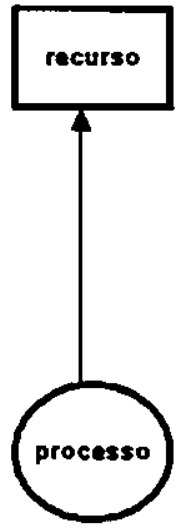

(b)

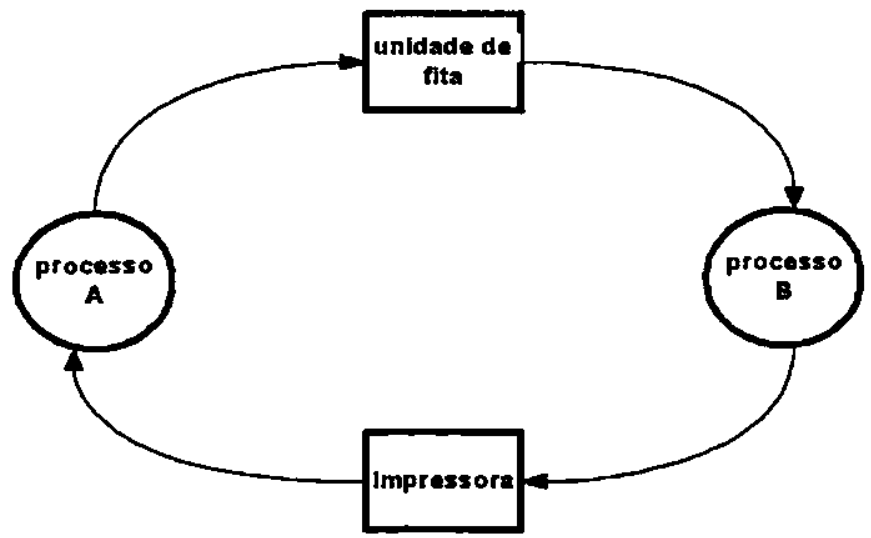

(c)

(a) Um processo de posse de um recurso

(b) Um processo aguardando por um recurso

(c) Deadlock

A figura 4.2 apresenta um exemplo [Tanenbaum, 1992] com sete processos identificados de $\mathrm{A}$ até $\mathrm{G}$ e seis recursos de $\mathrm{R}$ a W. Analisando-se o exemplo, observa-se que:

1. O processo A está de posse do recurso $R$ e precisa de $S$.

2. O processo $B$ não está de posse de nenhum processo, mas precisa de $T$.

3. O processo $C$ não está de posse de nenhum recurso, mas precisa de $S$. 
4. O processo $\mathrm{D}$ está de posse de $\mathrm{U}$, e precisa de $\mathrm{S}$ e de $\mathrm{T}$.

5. O processo $\mathrm{E}$ está de posse de $\mathrm{T}$, e precisa de $\mathrm{V}$.

6. O processo $\mathrm{F}$ está de posse de $\mathrm{W}$, e precisa de $\mathrm{S}$.

7. O processo $\mathrm{G}$ está de posse de $\mathrm{V}$, e precisa de $U$.

Toda vez que em um dígrafo de recursos for encontrado um ciclo, os processos que fizerem parte desse ciclo encontram-se em deadlock. Dessa forma, pode-se observar na figura 4.2, que os processos D, E e G estão em deadlock.

Existem vários algoritmos para detectar ciclos em grafos dirigidos. $\mathrm{O}$ grande problema é que a maioria desses algoritmos possui complexidade exponencial.

Essa técnica só é adequada quando existe apenas um recurso de cada tipo. Quando se trabalha com mais de um recurso de um mesmo tipo é necessária a utilização de estruturas de dados capazes de identificar cada recurso do sistema. Essas estruturas devem conter informaçōes sobre quais recursos estão disponíveis e quais estão alocados, além das informaçōes sobre os recursos a alocar e recursos alocados para cada processo.

Nessa abordagem para detecção de processos em deadlock, os processos começam desmarcados. Cada processo será marcado se ele puder terminar a sua execução sem provocar deadlock. Quando o programa de análise terminar, os processos que ainda estiverem desmarcados estarão em deadlock.

Inicialmente o algoritmo procura por um processo desmarcado $P$, e verifica se a quantidade de recursos que ele necessita é menor do que a quantidade de recursos disponíveis. Isto indica que esse processo terá condições de terminar a sua execução. Assim, o processo é colocado para executar até terminar. Se todos os processos estiverem em condições de executar, nenhum deles entrará em deadlock. Se existirem processos que nunca irão possuir condições para entrar em execução, estarão em deadlock.

Uma característica interessante dessa técnica é que apesar do algoritmo ser não determinístico, o resultado é sempre o mesmo. O problema é que o sistema deve saber desde a criação do processo, os recursos que ele vai utilizar durante a sua execução. Em termos de depuração, isto não é um problema muito dificil, pois em uma análise estática do código é possivel conseguir essas informações.

Os algoritmos que implementam a detecção do deadlock verificam a ocorrência da espera circular, percorrendo toda a estrutura, toda vez que um processo precisa de um recurso e esse pode ser imediatamente garantido.

O problema do deadlock tende a se tomar cada vez mais freqüente considerando a evolução que os sistemas operacionais tem alcançado no sentido de implementar o 
paralelismo de forma intensiva, permitindo uma maior alocação de recursos.

Figura 4.2 - Um dígrafo de recursos com a ocorrência de um ciclo [Tanenbaum, 1992].

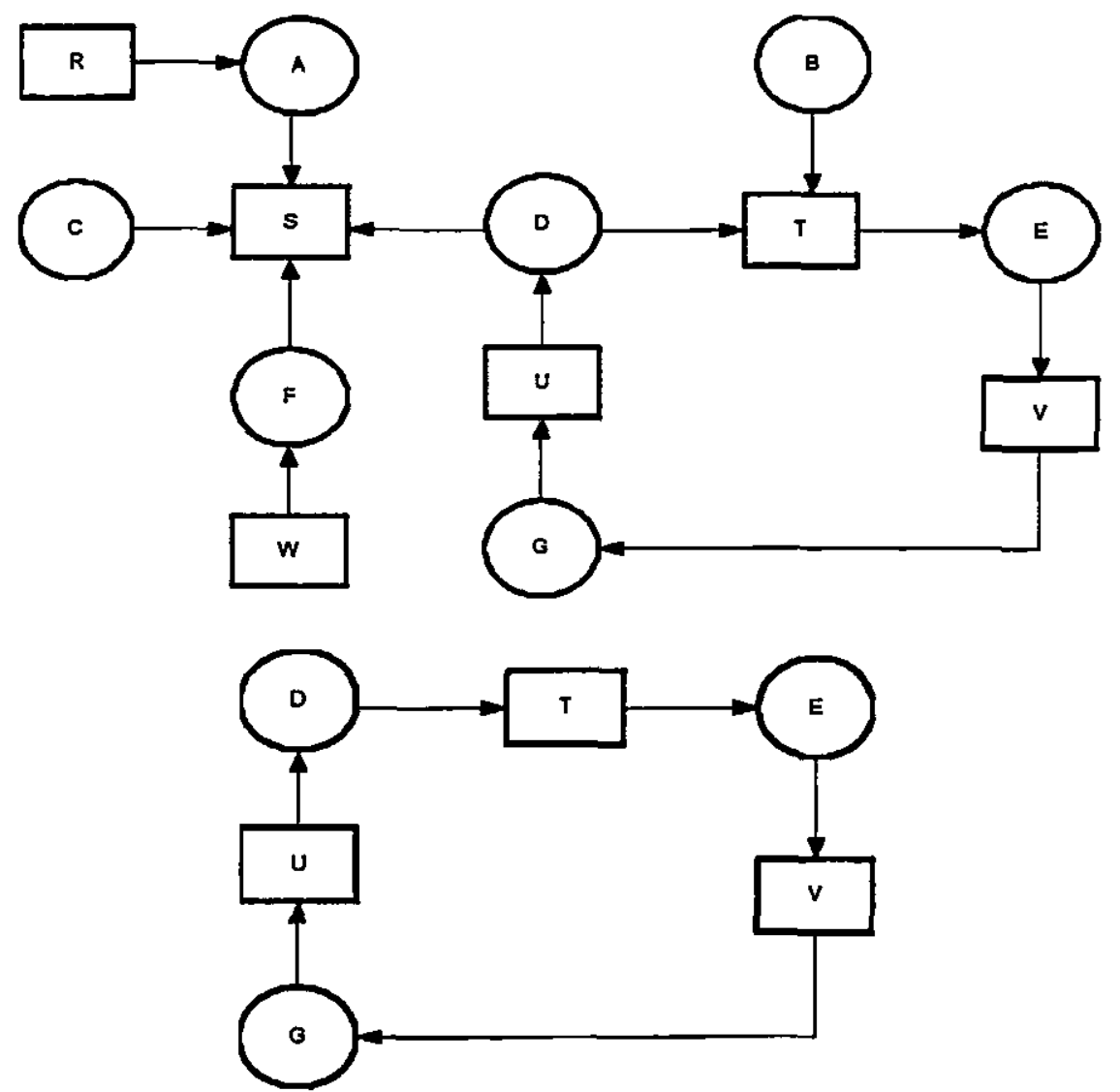

Ciclo extraido do digrafo anterior.

A deteçã̃o do deadlock se baseia na tentativa de se buscar estados seguros durante a execução de um processo. Existe um estado seguro em relação a um processo, quando esse processo puder executar e não entrar em deadlock alocando todos os recursos de que necessita.

Quando um sistema operacional adota a altemativa de detecção são, automaticamente, utilizadas técnicas de recuperação do deadlock. Existem várias formas de se realizar essa recuperação. Uma maneira seria através da preempção do recurso, quando isto é possível, transferindo o controle para um outro processo e devolvendo em seguida. Outra forma é retornar para um estado anterior a ocorrência de deadlock, pois quando ocorre o deadlock, o sistema percebe quais são os recursos que vão causar, ou que causaram a situação. Quando não é possível utilizar nenhuma dessas altemativas, a solução mais simples é "matar" um dos 
processos envolvidos liberando os seus recursos. Mesmo assim, não são todos os tipos dê processos que podem ser eliminados sem provocar um problema ainda maior.

Nesse trabalho, não serão abordados em detalhes, as formas de se recuperar os deadlocks após a sua detecção, pois o que interessa saber é se um programa paralelo pode entrar em deadlock interno, ou seja, causado pela má administração da alocação de recursos entre as suas próprias tarefas.

\section{4 - Deadlocks em Sistemas Distribuídos}

O problema do deadlock nos sistemas distribuídos possui a mesma conceituação em relação aos sistemas centralizados. $O$ deadlock ocorre principalmente durante a troca de mensagens entre os processos que estão executando nas diversas máquinas. Entretanto, se as mensagens forem tratadas como recursos, tem-se uma situação bastante parecida em relação aos outros recursos do sistema. Em sistemas distribuídos, a prevenção de deadlock é ainda mais dificil, devido aos componentes estarem fisicamente separados.

Para se detectar a ocorrência de deadlock é necessário eleger um processo coordenador. Isto porque em cada máquina é possível a criação de um grafo de recurso próprio, mas é extremamente complicado manter um grafo que envolva todos os recursos de todas os componentes computacionais. O coordenador manteria um estado global do sistema, mas se torna um ponto único de falhas.

Dentro de um programa paralelo, o controle é mais simples de ser feito, pois a responsabilidade pode ficar a cargo da própria aplicação. Essa é a vantagem de um depurador que consiga perceber a ocorrência de deadlock durante a fase de teste. 


\section{Capitulo 5 \\ Interface Homem-Máquina e Sistemas Tutores}

Quando um projeto computacional adquire funções educacionais, como é o caso desse trabalho, inevitavelmente os temas interface homem-máquina e sistemas tutores são abordados. O sucesso de uma ferramenta que pretende ensinar algum conteúdo para um usuário, está diretamente relacionado com a facilidade que esse usuário encontra na interação com a ferramenta. Além da interface, a ferramenta precisa ter um sistema tutor que possa conduzir o usuário de uma forma suave, sem provocar saltos na apresentação dos conteúdos. Esses saltos, em várias situações, provocam conclusões erradas por parte dos usuários.

Um dos objetivos desse projeto é permitir que os usuários iniciantes da programação concorrente possam adquirir novos conhecimentos com o exame das possíveis falhas em seus programas paralelos. $\mathrm{Na}$ busca desse objetivo, devern ser focalizados os temas: interface homem-máquina e sistemas tutores para que o esforço não seja em vão.

\section{1 - Interface Homem-Máquina}

As interfaces homem-máquina vêm ganhando destaque nos últimos anos. Os primeiros programas para computador foram desenvolvidos por engenheiros, sendo por eles utilizados. Não existia a preocupação de se criar um ambiente amigável. $O$ essencial era 0 programa apresentar as respostas esperadas, mesmo que essas respostas só fossem compreensíveis aos programadores e as entradas só pudessem ser realizadas por quem entendia o funcionamento do programa em detalhes, que geralmente eram os próprios programadores.

Mesmo hoje é possível verificar a diferença entre dois programas desenvolvidos pelo mesmo programador. Quando um dos programas está sendo desenvolvido para o uso do 
próprio programador, a preocupação com a interface fica para segundo plano, pois o programador sabe os passos que precisa efetuar para se realizar alguma tarefa em seu programa e compreende os resultados apresentados. Quando o programa está sendo criado para uma terceira pessoa, a preocupação com a interação do usuário com o programa deve ser maior. $O$ desenvolvedor não deve esquecer que para o usuário o programa que ele utiliza é uma caixa preta.

A interface homem-máquina é o comportamento do usuário e do computador que pode ser observado externamente, existindo uma linguagem de entrada, outra de saida e um protocolo de interação [Chi, 1985]. Em outras palavras, a interface homem-máquina é a parte de um software responsável pela interação entre o usuário e o computador, traduzindo as ações do usuário em ativações das funcionalidades do sistema, e pela apresentação em forma adequada dos resultados.

\subsection{1 - Aspectos da Percepção Humana}

O ser humano interage com o meio em que vive por meio de um sistema sensorial bem desenvolvido [Pressman, 1992]. Em se tratando de interface homem-máquina, os sentidos predominantes são o visual, o tátil e o auditivo. Desses o mais importante é o sentido visual, já que a maioria das informações que são apresentadas aos usuários é feita através de imagens (monitor) ou relatórios.

Uma pessoa interpreta uma informação através de uma imagem, muito mais rapidamente que a mesma informação em um texto. Ainda assim, alguns dos sistemas computacionais interagem com o usuário na forma textual, mesmo aqueles baseados em ambientes gráficos.

Um bom tratamento visual de um software com objetivos educacionais permite uma maior assimilação por parte do educando, facilitando o processo ensino-aprendizagem.

Um detalhe importante no estudo das interfaces, é que cada ser humano possui personalidade única. Nem tudo que agrada a uma pessoa agrada a outra. Apesar disto existem padrões que devem ser observados, mas a interface ideal será aquela que possuir flexibilidade para permitir ao próprio usuário algumas caracteristicas que adaptem ao seu gosto.

\subsection{2 - Interface User-friendly}

Um dos objetivos do projeto de interface homem-máquina é criar uma interface que seja amigável. Habermann apresenta uma semântica para definir uma interface "amigável" [Habermann, 1991]:

(1) A interface deve ser transparente, ou seja, o usuário concentra-se nas tarefas que 
pretende realizar;

(2) Deve ser previsível e ao mesmo tempo flexível. Nem sempre o usuário possui condições de recorrer ao manual para entender o que realiza uma opção;

(3) O usuário deve gostar dela. Muitos usuários finais preferem sistemas que são inferiores, em termos de eficiência, mas que são făceis de usar.

O projeto de interfaces é um importante ramo dentro da ciência da computação, pois a interface atua diretamente na produtividade do usuário. A popularização da informática devese muito a evolução das técnicas de projeto de interface.

Além do preço do hardware e o custo de desenvolvimento do software, um sistema computacional ainda necessita treinar os usuários. Quanto mais dificil o aprendizado mais caro fica o sistema, além de aumentar no usuário a rejeição ao sistema.

\subsection{3 - Interface e Aprendizagem}

A interface alcança grande destaque quando se trata de informática e educação, ou aprendizagem através do computador. Uma interface bem projetada pode facilitar o aprendizado do usuário enquanto que uma interface em que o usuário sinta dificuldade de interação pode criar situações dificeis de serem resolvidos.

Quando a interface possui o objetivo de servir de apoio ao aprendizado, é interessante a análise das caracteristicas que possam tornar a comunicação a mais simples possível. A interface deve fazer uso de recursos multimídia, linguagem natural etc, explorando bastante o sentido auditivo, além do visual que já é bastante utilizado.

\subsection{4 - Construçăo de Uma Interface}

O desenvolvimento de uma interface é um processo iterativo. A cada iteração, as versões do projeto são refinadas e testadas com os usuários que interagem com o desenvolvimento, melhorando a definição da interface. A interface só deve ser implementada após várias iteraçőes com o usuário. Mesmo assim, poderá ser necessário realizar novas alterações quando a ferramenta já estiver pronta, pois a implementação pode revelar dificuldades que não foram observadas durante o projeto.

0 projeto de interface define o comportamento e a apresentação de uma interface envolve fatores da psicologia humana, tecnologia dos dispositivos de entrada e saida, tipos de diálogos, análise de tarefas, princípios, padrões, regras, protótipos e avaliação de sistemas existentes. 


\subsection{5 - Modelos de Projeto de Interface}

Basicamente, existem quatro modelos de projeto de interfaces e cada modelo representa a interface sob um ponto de vista diferente [Pressman, 1992]. O primeiro é o modelo de projeto, que é a especificação criada pelo desenvolvedor contendo a funcionalidade de todo o sistema. $\mathrm{O}$ segundo modelo é o modelo de usuário, que descreve o perfil dos usuários, como nivel de conhecimento, educação, capacidades fisicas, idade, sexo, etc. $\mathrm{O}$ objetivo desse modelo é focalizar a que usuário a ferramenta se destina. $\mathrm{O}$ terceiro modelo é a percepção do sistema, que representa a imagem que o usuário tem do sistema. Por fim, o último modelo é a imagem do sistema, que é a interface final do sistema. Se a imagem do sistema e a percepção do sistema forem iguais, o usuário terá satisfação ao utilizar o sistema.

\section{2 - Sistemas Tutores e Sistemas Tutores Inteligentes}

Os sistemas tutores inteligentes (S.T.I.) surgiram da interseção da Ciência da Computação, da Psicologia Cognitiva e da Pedagogia. A Ciência da Computação fornece as técnicas para representar e manipular o conhecimento. A Psicologia Cognitiva apresenta as formas de construção desse conhecimento pelo ser humano e a Pedagogia estuda como melhorar as formas de ensino-aprendizagem [Freire, 1998].

Os sistemas tutores inteligentes são uma evolução natural dos sistemas tutores. Os sistemas tutores se limitam a apresentar tópicos que são selecionados pelos usuários com intuito de obter as informações referentes. $O$ grande problema que surge com esse tipo de sistema é a falta de flexibilidade que é extremamente importante em um processo educacional.

Um sistema inteligente para o ensino deve ser capaz de perceber certas deficiências do usuário, remontando-o a tópicos básicos para maior fixação do conteúdo. $\mathrm{O}$ sistema não pode permitir que o aluno interaja com tópicos que ainda não possui condições de assimilar, para que não surjam bloqueios dificultando a aprendizagem. Deve, ainda, proporcionar um diagnóstico detalhado dos erros do usuário, ao invés de mostrar simplesmente como realizar a tarefa.

Além disso, o usuário deve se sentir diante de um "professor" podendo propor questionamentos novos e responder às questões que o sistema formula. Quanto menos o usuário percebe que está diante de uma máquina, maior é o alcance do sistema. 


\subsection{1 - A Arquitetura de um Sistema Tutor Inteligente}

Geralmente, um sistema tutor inteligente é composto dos seguintes módulos [Freire, 1998]:

(1) Módulo Especialista: que possui os predicados e as regras de um domínio particular. É a origem do conhecimento que deverá ser absorvida pelo usuário.

(2) Modelo do Estudante: armazena o desempenho do estudante, sendo a estrutura básica para as tomadas de decisão do sistema.

(3) Módulo Tutorial: regula as interações de aprendizagem do sistema com o estudante. Esse módulo define as atividades pedagógicas que serão propostas ao aluno pelo sistema.

(4) Módulo de Interface: é o módulo da interface homem-máquina, ou seja, a interface do sistema tutor com o usuário.

Um sistema baseado em conhecimento faz uso intenso de conhecimento especializado. O objetivo desses sistemas é tentar resolver problemas da mesma forma que um especialista humano resolveria.

Um sistema tutor inteligente também é classificado como um sistema baseado em conhecimento, visto que o sistema deve armazenar o conhecimento sobre as características do usuário, bem como o conhecimento especialista sobre determinado domínio. Um sistema baseado em conhecimento constitui-se de:

(1) Núcleo de Sistema Baseado em Conhecimento: que realiza a interação com o usuário ou equipamentos externos, produz um conhecimento baseando-se em alguma linha de raciocínio e apresenta as conclusões a partir desse raciocínio;

(2) Base de Conhecimento: é onde fica armazenado o conhecimento especialista;

(3) Base de Dados: é onde se armazenam as conclusões intermediárias e as provas realizadas durante a execução do programa, permitindo fornecer ao usuário as provas correspondentes às conclusões obtidas.

\subsection{2 - Aquisição de Conhecimento}

A aquisição de conhecimento é um tópico importante em um sistema inteligente. 0 conhecimento adquirido agiliza as tomadas de decisões futuras. Em se tratando de software tutores, a aquisição de conhecimento facilita as interações entre o usuário e o computador, permitindo um aprendizado mais făcil por parte do usuário.

\subsection{3 - O Ensino da Programação de Computadores Através de Um S.T.l.}

Do ponto de vista da cognição, a programação de computadores é uma tarefa dificil 
para iniciantes. Isto ocorre por duas razões: a falta de conhecimento dos princípios que envolvem a programação e a falta de perícia do aluno [Pimentel e Direne, 1998]. Como qualquer área, as técnicas de programação de computadores também podem ser ensinadas utilizando-se um Sistema Tutor Inteligente. É possível, por exemplo, desenvolver um sistema que auxilie um professor de Linguagens e Técnicas de Programação, através de exercícios que possam ser modificados pelo próprio sistema, aumentando as altemativas do estudante. 0 sistema auxiliaria o usuário na correção dos erros que ele ainda estiver cometendo. Um sistema desses permite minimizar o tempo de aprendizado possibilitando a utilização de diversas estratégicas pedagógicas.

A aprendizagem da programação paralela tende a se tornar mais suave com o auxilio de um sistema tutor. $O$ objetivo das ferramentas não é eliminar a figura do professor, mas ampliar o potencial pedagógico durante o processo de ensino-aprendizagem. A utilização da informática no processo pedagógico ainda não logrou grande sucesso. Isto se deve ao fato de se usar o computador da mesma forma que se usa um livro ou o quadro negro. É preciso utilizar o computador explorando o seu potencial característico, sem desmerecer os outros mecanismos pedagógicos, mas utilizando a computação com as técnicas que ela possui de especial.

A grande dificuldade existente na criação de uma ferramenta assim é como selecionar os exemplos em que o aluno está apto a resolver, ou seja, como definir o grau de dificuldade de um programa. A engenharia de software usa medidas como linhas de código (LOC) ou pontos por função (FP) [Pressman, 1992], mas essas medidas não são precisas porque nem sempre um programa extenso é mais dificil de se desenvolver que um pequeno.

Em adição, é possível unir um sistema tutor inteligente para o aprendizado das técnicas de programação com um sistema de depuração proporcionando um sistema de aprendizado bastante eficaz. 


\section{Capítulo 6 \\ O Projeto de Um Ambiente Para Depuração de Programas Paralelos}

Devido à diversidade de linguagens para a criação de programas paralelos e à existência de várias bibliotecas para a criação de ambientes de portabilidade, são poucas as ferramentas para a depuração de programas paralelos. $O$ foco principal das pesquisas que estão em desenvolvimento nessa área, procura enfatizar os problemas que estão envolvidos com a depuração de programas paralelos, apresentando conceitos que definem as regras para se depurar um programa, mas não envolvem o desenvolvimento de uma ferramenta que integre a parte de teste e depuração do programa em um ambiente de aprendizagem.

As ferramentas de depuração existentes não possuem uma boa interface e não têm a preocupação de conduzir o usuário a uma melhor utilização da linguagem. Normalmente, as ferramentas disponiveis são especificas para um sistema e visam apenas detectar erros.

O objetivo deste trabalho é projetar uma ferramenta que auxilie um usuário de programação paralela, sem muita experiência, a localizar erros em seus programas. A ferramenta deverá conter um ambiente tutor, para que durante a localização dos possiveis problemas que estão provocando os erros, conduza o usuário a uma reformulação de suas técnicas de programação. Esse procedimento proporciona a aquisição de novos conhecimentos sobre a prática da programação paralela, ou ainda consolida conceitos anteriormente adquiridos. A utilização de ilustrações que mostrem alternativas para se resolver as situaçðes que surgem quando se trabalha com um programa paralelo são consideradas.

A ferramenta está estruturada através de uma arquitetura em camadas como pode ser visto na figura $\ddot{6.1}$. Cada camada se comunica com a seguinte através de protocolos, permitindo uma maior independência na definição e implementação do projeto. 
Figura 6.1 - As Camadas que Definem o Projeto.

\begin{tabular}{l|c|}
\cline { 2 - 2 } Nivel 4 & Apresentação \\
\cline { 2 - 2 } Nível 3 & Tutor \\
\cline { 2 - 2 } Nível 2 & Depuração \\
\cline { 2 - 2 } Nível 1 & Biblioteca \\
\cline { 2 - 2 } Nivel 0 & Arquitetura \\
\cline { 2 - 2 } &
\end{tabular}

A camada de Arquitetura, localizada na base da estrutura e por isso no nível zero, define $o$ ambiente em que o programa paralelo irá executar (não necessariamente o ambiente em que a ferramenta está executando). Com essas informações é possivel traçar a granulosidade adequada para o programa. Essas informações são utilizadas pelas camadas de depuração e também pela camada tutor, para verificar se as técnicas de comunicação e sincronização usadas no desenvolvimento do programa estão adequadas à arquitetura utilizada.

A segunda camada, Biblioteca, é semelhante à primeira. Define as ferramentas utilizadas no programa que será depurado, isto é, as linguagens e as bibliotecas que foram usadas na elaboração do programa.

O depurador se localiza na terceira camada da arquitetura, ou seja, a camada de Depuração (nível 2). Essa camada se divide em módulos funcionais. Cada módulo tem o objetivo de resolver um tipo de problema específico. Por exemplo, um módulo para resolver problemas de deadlock e espera infinita e outro que resolva problemas de sincronização e comunicação. Além disso, deve ter um módulo para a busca de possíveis problemas de ordem seqüencial que podem estar afetando o programa como um todo. Por exemplo, se uma tarefa possui um loop codificado de forma incorreta gerando uma repetição "infinita" e logo em seguida a esse loop, essa tarefa precisa enviar uma mensagem para todos as outras que compõe a aplicação. A tarefa que está aguardando pela mensagem ficará esperando indefinidamente, devido a um problema na parte seqüencial do código.

O depurador possui características estáticas pela própria necessidade de interação do usuário com o sistema tutor.

Com o resultado que a camada anterior produziu, a camada Tutor (nivel 3) proporciona a usuário um mecanismo de ensino, facilitando o entendimento das falhas que 
foram realizadas durante a implementação e criando um ambiente que melhora o aprendizado da programação paralela. Esse ambiente tutor pode, futuramente, se tornar um sistema tutor inteligente.

Finalmente, a camada de Apresentação (nível 4) possui como objetivo criar uma representação gráfica do programa que está sendo analisado, permitindo a apresentação de várias janelas com imagens de cada passo da execução do programa, permitindo montar uma animação do seu funcionamento, pois isto não é possivel na camada de depuração visto que o depurador se baseia em técnicas estáticas. Além disso, é possível trabalhar essa camada para criar testes para os programas paralelos.

A seção 6.2 mostra o modelo proposto para a ferramenta e apresenta o relacionamento entre as camadas descritas nessa seção e os processos do modelo.

\section{1 - O Modelo da Ferramenta}

O projeto de um sistema ou de uma ferramenta, como a proposta nesse trabalho, pode ser visto como a construção de um edificio, que obedece a fases e procedimentos bem definidos. Em um primeiro instante, trabalha-se a criatividade, ou seja, parte-se de uma idéia inicial que é a base de tudo. Nesse caso, o ponto de partida foi a estrutura em camadas apresentada na seção anterior (figura 6.1). Entretanto, para ir além é necessário uma metodologia. Uma metodologia pode ser definida como um conjunto de métodos e técnicas com os quais uma tarefa pode ser cumprida, em outras palavras, uma metodologia estabelece um caminho único no desenvolvimento de projetos novos ou na evolução de um projeto já existente [Machado e Abreu, 1995].

Uma metodologia de projeto consiste na construção de um modelo do domínio de um problema e da adição de detalhes de implementação ao modelo durante o projeto do sistema.

Para a criação de um modelo inicial que possibilite a visualização e definição das tarefas que compõem a ferramenta proposta nesse trabalho, além do inter-relacionamento entre elas, está sendo utilizada a ferramenta de projeto de sistemas denominada DFD Diagramas de Fluxos de Dados [Davis, 1994] [Gane, 1988] [Gane e Sarson, 1988] definida na metodologia da análise estruturada de sistemas.

O diagrama da figura 6.2 representa os processos e as informações que trafegam nas 5 camadas que compõem a ferramenta. O processo 1 - Preparar Dados de Arquitetura $e$ Biblioteca, está contido nas camadas 1 e 2 e possui a função de atualizar as informações da arquitetura (hardware) onde está executando a aplicação a ser depurada e as informações referentes às linguagens e bibliotecas utilizadas (software). O processo 2 -Montar Grafos de 
Entrada faz parte da terceira camada (camada de depuração). Esse processo é responsável em criar duas classes de grafos: grafos de fluxo de instruções ou grafos de caminho e grafos de sincronização. Os grafos de caminho representam todos os caminhos possiveis de serem executados pelo programa e os grafos de sincronização representam as alternativas dos caminhos existentes nas comunicações entre os processos. A definição desses grafos será vista no item 6.2.2. Esses grafos são armazenados em um arquivo para a posterior utilização pelo processo 3 - Depurar o Programa, responsável pela depuração propriamente dita. $O$ processo 3 possui subprocessos, cada um representando uma função, ou seja, resolvendo uma classe de erros em programas paralelos. Ao final de sua ação, esse processo armazena os resultados da depuração para serem utilizados pelos processos 4 e 5 . 0 processo 4 - Criar Ambiente Tutor representa a quarta camada da arquitetura (camada Tutor). Com base nos erros encontrados, esse processo cria um ambiente de comunicação com o usuário, promovendo alternativas para solucionar o problema. O processo 5 - Montar Grafos de Simulą̧ão representa a quinta camada da arquitetura (camada Apresentaçăo). Esse processo permite ao usuário verificar o efeito que os erros encontrados provocam no programa, através da simulação da execução do programa pelos grafos correspondentes. Esse processo permite a elaboração de testes para o programa, que apesar de não ser o foco inicial da ferramenta, é possível de ser realizado através da composição dos dados que passam pelo processo.

Figura 6.2 - Estrutura dos Fluxos e dos Dados da Ferramenta ( $\left(^{\circ}\right.$ Modelo)

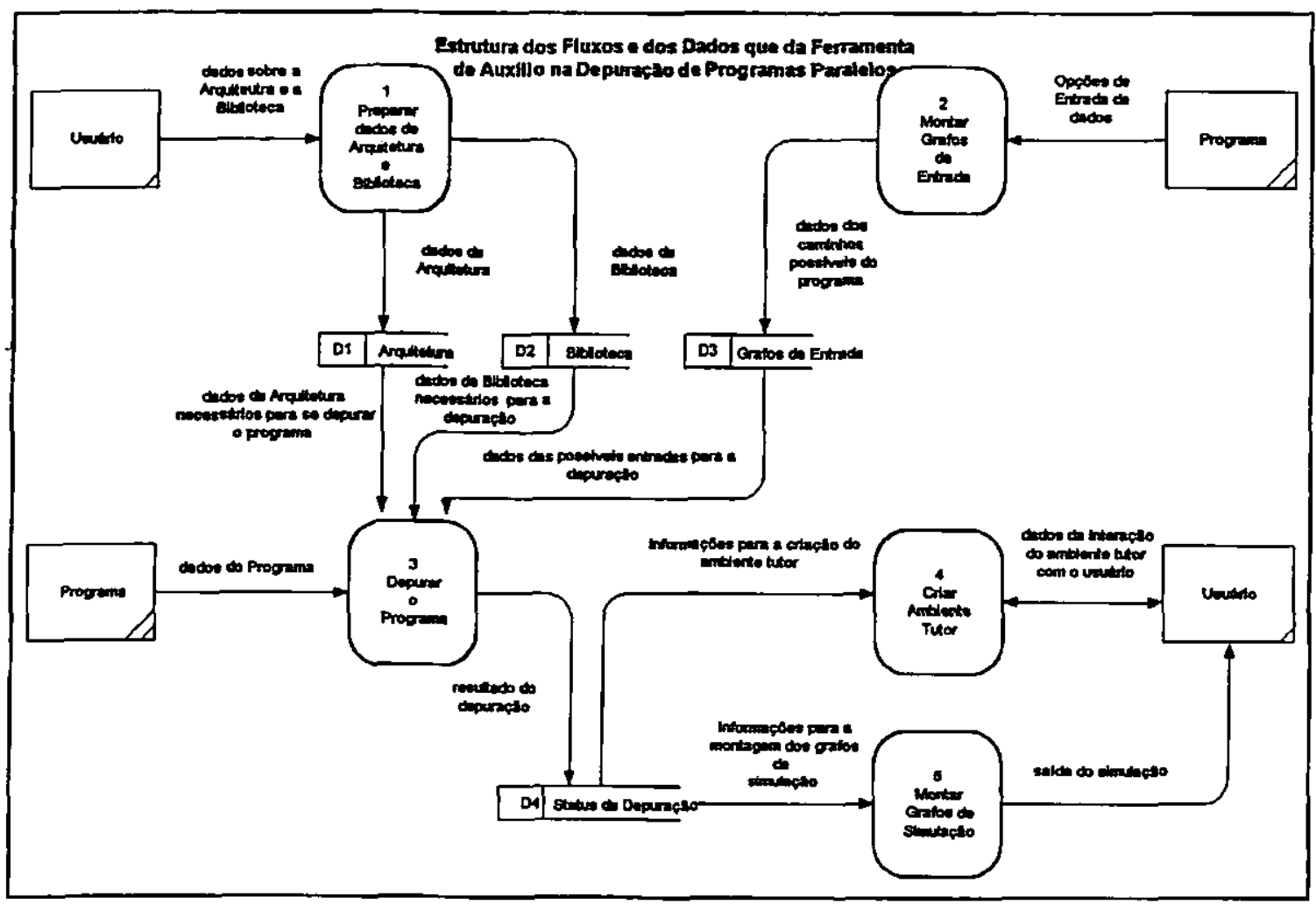


Através da análise desse modelo é possivel verificar a flexibilidade que ele oferece para explorar outras funcionalidades, como por exemplo, a paralelização automática do código que pode ser obtida pelo processo 5 (Montar Grafos de Simulação).

Pode parecer estranho o desejo de paralelizar um programa paralelo. Entretanto, a ferramenta é destinada aos usuários iniciantes. Possivelmente o código que está sendo depurado apresenta trechos seqüenciais que poderiam ser codificados paralelamente e que passou "despercebido" pelo usuário. $O$ processo 5 pode avaliar as precedências nos grafos que representam o fluxo de instruções do programa e sugerir uma melhor divisão das tarefas. Para criar essa funcionalidade é necessário que o processo tenha acesso aos grafos que representam o programa, além das informaçōes contidas nos depósitos: Biblioteca (D2) e Arquitetura (DI). Assim, o modelo pode ser melhorado com a adição dos fluxos desses depósitos no processo 5 .

Figura 6.3 - Estrutura dos Fluxos e dos Dados da Ferramenta (Modelo Final).

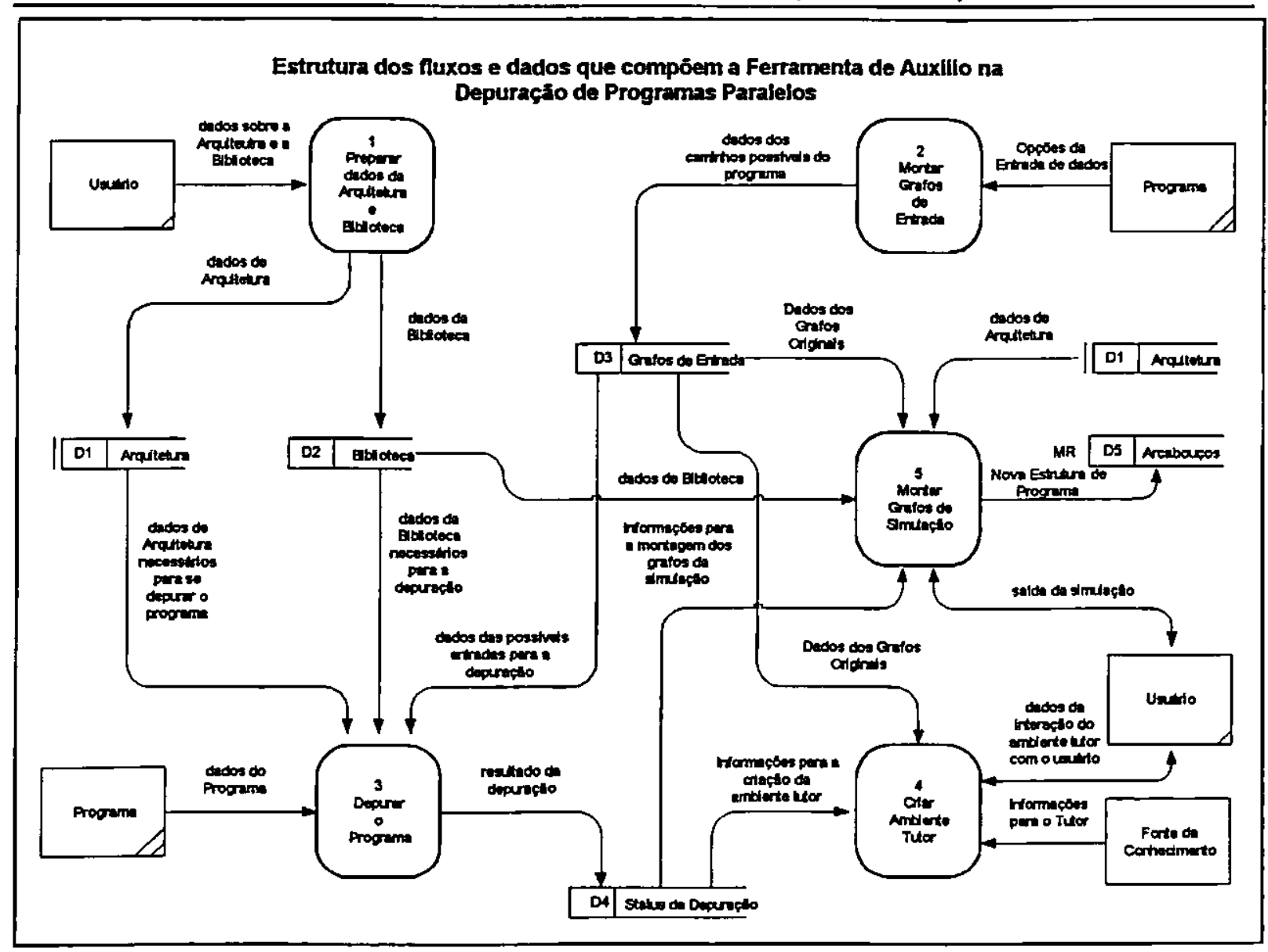

Outra mudança que pode ser feita no modelo original, é o acréscimo de um depósito de dados diretamente relacionado com o processo 5 (Montar Grafos de Simulação). Esse depósito terá a função de armazenar os grafos que serão o resultado da paralelização 
automática ou modificações que forem realizadas pelos usuários diretamente nos grafos. Com essa saida, outras ferramentas que trabalham com geração automática de código poderão utilizar esses dados para gerar novas estruturas de programas a partir dos grafos corrigidos [Branco, 1999]. O resultado dessas modificações pode ser visto na figura 6.3.

A seguir será detalhada a estrutura interna de cada processo que compõem o modelo.

\subsection{1 - Processo 1 - Preparar Dados de Arquitetura e Biblioteca}

A camada de arquitetura tem como objetivo definir o ambiente em que o programa paralelo está implementado. Essas informaçōes dizem respeito às caracteristicas da arquitetura paralela, por exemplo, se o ambiente é fortemente acoplado ou fracamente acoplado; ou ainda, se representa um sistema distribuído ou uma máquina paralela, além de outras informações relevantes, como a quantidade de elementos de processamento, quantidade de memória, etc.

O desenvolvimento das arquiteturas paralelas visa melhorar o desempenho dos sistemas computacionais. Para alcançar esse objetivo, surgem obstáculos como o alto custo do desenvolvimento do hardware e do software, além da dificuldade encontrada pelos programadores em adequar o software paralelo à arquitetura, maximizando o paralelismo do programa e utilizando uma granulosidade mais adequada à arquitetura.

As arquiteturas paralelas podem ser definidas como "um conjunto de elementos de processamento que podem se comunicar e cooperar para resolver grandes problemas rapidamente" [Almasi e Gottlieb, 1994]. Essa definição cria uma abstração sobre o conceito de arquiteturas paralelas, permitindo que sejam elaboradas questões relativas aos elementos de processamento, aos mecanismos de comunicação, a cooperação entre esses elementos de processamento e sobre o que significa resolver grandes problemas rapidamente [Calônego, 1997]. Analisar todas as arquiteturas paralelas com as possiveis combinações para os dispositivos de entrada e saida, que crescem exponencialmente, não é uma tarefa fácil e nem recomendável. Entretanto, o estudo dessas informações aumenta consideravelmente a aplicabilidade dessa ferramenta, pois possibilita uma análise mais detalhada de um programa paralelo.

A busca de erros em um programa se restringe à análise semântica e sintática, aos testes de caixa preta e na verificação da adequação dos objetivos alcançados com a análise de requisitos, que é a especificação do que o software deve fazer. Um software paralelo possui outros aspectos que devem ser analisados, como a sua eficiência.

Um estudo da eficiência de um software paralelo deve se pautar na análise do grau de paralelismo alcançado no programa. Além disso, é fundamental o casamento entre o software 
e o hardware, ou seja, a granulosidade explorada no programa deve estar sincronizada com as características do hardware.

O protocolo de saída dessa camada será utilizado pelas camadas de depuração e também pela camada tutor, com o objetivo de verificar se as técnicas de comunicação e sincronização usadas no desenvolvimento do programa estão adequadas. Além disso, com essas informações é possível traçar a granulosidade ideal do programa paralelo. Isto possibilita à ferramenta perceber as falhas relacionadas com o desempenho do programa e sugerir novas estratégias na divisão das tarefas que compõem a aplicação.

Figura 6.4 - Explosăo do Processo 1 - Preparar Dados de Arquitetura e Biblioteca.

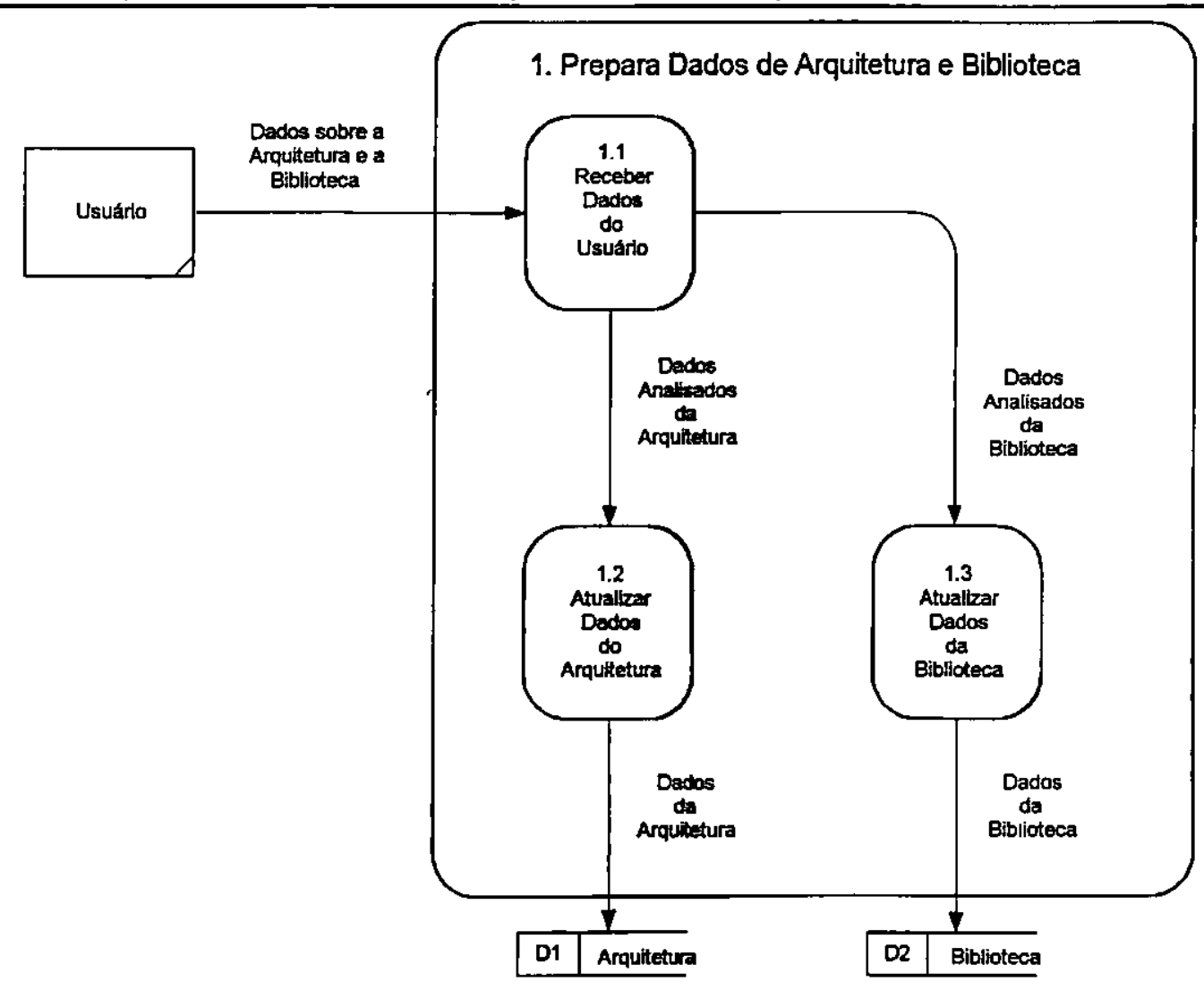

A figura 6.4 apresenta o detalhamento desse processo. É possivel observar que o processo 1.1 - Receber Dados do Usuário faz parte da interface com o usuário, sendo responsável pela verificação da consistência dos dados recebidos. Os processos 1.2 Atualizar Dados da Arquitetura e 1.3 - Atualizar Dados da Biblioteca são responsáveis pelo armazenamento dos dados recebidos. Futuramente, será possível acrescentar um depósito de dados com informações de arquiteturas que foram avaliadas por software benchmarks. Essas informaçōes poderão proporcionar um maior realismo durante a simulação do comportamento do programa, através da definição de unidades de tempo proporcionais às diferenças de tempo 
dos processadores. Essas diferenças poderão ser percebidas pelos usuários durante a simulação, pois o tempo de simulação de cada tarefa estará associado à unidade de tempo atribuida ao processador na qual ela está alocada.

A seguir serão apresentadas as informaçōes que devem ser tratadas na camada de arquitetura:

(1) Arquitetura do Ambiente: Esse item define o tipo de estrutura física do ambiente paralelo, ou seja, a arquitetura onde o programa executará: Sistema Distribuído, SP2, etc.

(2) Elementos de Processamento: Fixa o número de processadores que compõem a máquina paralela e os atributos desses processadores como: capacidade de endereçamento, clock, fabricante, familia a que pertence, dentre outras.

(3) Memória: As informaçōes da memória se dividem em dois grupos: memória fortemente acoplada e memória fracamente acoplada. No primeiro grupo os atributos são a velocidade de acesso e a capacidade máxima. $O$ segundo grupo possui os mesmos atributos, mas por se tratar de várias memórias, uma para cada elemento de processamento, há a subdivisão desses atributos em cada módulo.

(4) Barramento: Define o tipo de barramento que está sendo usado no momento da análise do desempenho do programa, como por exemplo: ISA, EISA, PCI, etc. O objetivo é definir a topologia de comunicação que está sendo utilizada, visto que a comunicação entre processos influencia diretamente no desempenho do programa. A informação sobre o barramento também incorpora o atributo da inferface utilizada para a conexão entre os componentes e seus respectivos meios de transmissão de dados. Em várias situações uma mesma interface pode ser utilizada por protocolos de comunicação e meios de transmissão distintos.

(5) Periféricos: são os dispositivos de entrada e saida de dados aos quais o processador não tem acesso direto.

(6) Informações Adicionais: Quando se tratar de um ambiente heterogêneo (Sistema Distribuído) será necessário informar quais os tipos de computadores que fazem parte do sistema, permitindo uma análise do balanceamento da carga utilizado na definição do programa paralelo.

Um estudo mais detalhado sobre as caracteristicas das arquiteturas paralelas pode ser encontrado em [Calônego, 1997].

Enquanto a camada de Arquitetura se responsabiliza pelo hardware, a camada de Biblioteca define as linguagens e bibliotecas que foram usadas na elaboração do programa e o 
número de tarefas que compõem a aplicação paralela.

Esta camada trata das seguintes informações:

(1) Linguagem Utilizada: Define a linguagem em que o programa foi codificado para que seja utilizada a biblioteca correta durante o processo de depuração. As linguagens que são apresentadas nessa camada só poderão estar disponíveis se já existir a implementação dos respectivos módulos para depuração.

(2) Biblioteca: Esse atributo é utilizado quando se trata de bibliotecas para troca de mensagem como, por exemplo, PVM.

(3) Sistema Operacional: Possui informações intrínsecas relativas à adaptação de componentes como drivers controladores dos dispositivos de comunicação e outros el ementos disponíveis num dado hardware.

(4) Quantidade de tarefas: Esse atributo define o número de tarefas projetadas pelo usuário na elaboração do programa. Desse modo, é possivel verificar se os comandos para criação de tarefas escravas possuem falhas e, ainda, verificar as relações das tarefas com o número de elementos de processamento que foram definidos na camada de arquitetura. Dependendo do programa que está sendo analisado, não será necessário especificar explicitamente esse atributo, pois a quantidade de tarefas pode ser extraída diretamente do código. Entretanto, a utilização explícita desse item permite verificar se o objetivo do usuário com relação às divisర̃es das tarefas do programa foi atingido.

(5) Arquitetura do Sistema: Diz respeito à forma como as tarefas estão divididas: SPMD (Simple Program Multiple Data) ou MPMD (Multiple Program Multiple Data).

Esse processo é responsável pela consistência das informações que os usuários inserem no sistema com relação à arquitetura e à biblioteca. Durante a implementação das versões finais para as linguagens existentes será necessária a existência de uma gramática livre de contexto ou BNF (Backus-Naur Form), para especificar a sintaxe das linguagens. Além de especificar a sintaxe da linguagem, uma gramática livre de contexto pode ser usada como auxílio para guiar a tradução de programas [Aho et al., 1995]. Dessa forma, um programa paralelo que apresente um aito grau de correctude na análise de seus grafos pode ser traduzido para outras linguagens que possuem abordagem de paralelismo semelhante.

\subsection{2 - Processo 2 - Montar Grafos de Entrada}

Dado um conjunto de objetos pode-se estar interessado no conteúdo desses objetos ou 
na estrutura do conjunto, ou seja, nas relações entre os objetos. A teoria dos grafos permite que sejam concentradas as atenções no segundo objetivo, criando uma abstração do primeiro ponto de vista.

Os grafos constituem uma ferramenta básica para modelar fenômenos discretos e são fundamentais para a compreensão das estruturas de dados e análise de algoritmos. Na próxima seção será visto como utilizar grafos para se representar programas de computador e como utilizar esses grafos para depurar os programas.

\subsubsection{1 - Grafos de Fluxo de Instrução e Grafos de Comunicação}

Um dos aspectos da depuração de um programa é o estudo da seqüência de execução do programa. A maneira como um programa paralelo executa depende dos dados de entrada, a seqüência das instruções e a comunicação e sincronismo que existe entre as tarefas [Furtado, 1973].

Um programa de computador pode ser representado através de um grafo $G=(N, A, f)$, onde:

- $\quad N=\left\{n_{l}, n_{2}, \ldots, n_{k}\right\}$ é um conjunto não vazio de vértices (nós) que representa os comandos executáveis do programa ou um conjunto de instruções executadas seqüencialmente;

- $A$ é um conjunto de arestas (arcos) que representa os caminhos do fluxo de instruções que o programa poderá percorrer;

- $f$ é uma função que associa cada aresta $a$ a um par não-ordenado $x-y$ de vértices chamados de extremos de $a$.

Ưm caminho é uma seqüência finita de nós $\left(n_{1}, n_{2}, \ldots, n_{k}\right), K \geq 2$, tal que existe um arco de $n_{i}$ para $n_{i+1}$ para $i=1,2, \ldots, k-1$, e representa uma seqüência de execução possível. Um caminho simples surge quando se passa apenas uma vez pelos arcos que o compõe. Quando s trata de um caminho simples diz-se que esse caminho é livre de laço.

Um caminho completo é um caminho onde o primeiro nó é o nó de entrada e o último nó é o nó de saida do grafo $\mathrm{G}$. Seja $\mathrm{IN}(\mathrm{x})$ e OUT(x) o número de arcos que entram e que saem de $x$, respectivamente. Se $\mathbb{N}(x)=0$ então $x$ é um nó de entrada, e se OUT $(x)=0$, então $x$ é um nó de saida.

Quando se utiliza as estruturas de um grafo para fazer testes ou depurar um programa, é interessante que todos os caminhos possíveis do programa sejam executados. Entretanto, essa é uma tarefa bastante dificil, devido ao grande número de possiveis caminhos que um programa pode fornecer.

A representação de um programa $\mathbf{P}$ como um grafo de fluxo de controle consiste em 
estabelecer uma correspondência entre nós e blocos e em indicar possiveis fluxos de controle entre blocos através dos arcos. $\dot{\mathrm{E}}$, portanto, um dígrafo com um único nó de entrada $n_{1} \in \mathrm{N}$ e um único nó de saída $n_{k}$, no qual cada vértice representa um bloco indivisivel de comandos e cada aresta representa um possível desvio de um bloco para o outro.

A tabela 6.1 apresenta os grafos que representam as estruturas básicas de um programa. As estruturas são apresentadas através de algoritmos para não se prender a sintaxe de uma linguagem especifica.

Através do grafo do fluxo de instruções podem ser escolhidos os componentes que devem ser executados, isto caracteriza um teste de caixa branca ou teste estrutural.

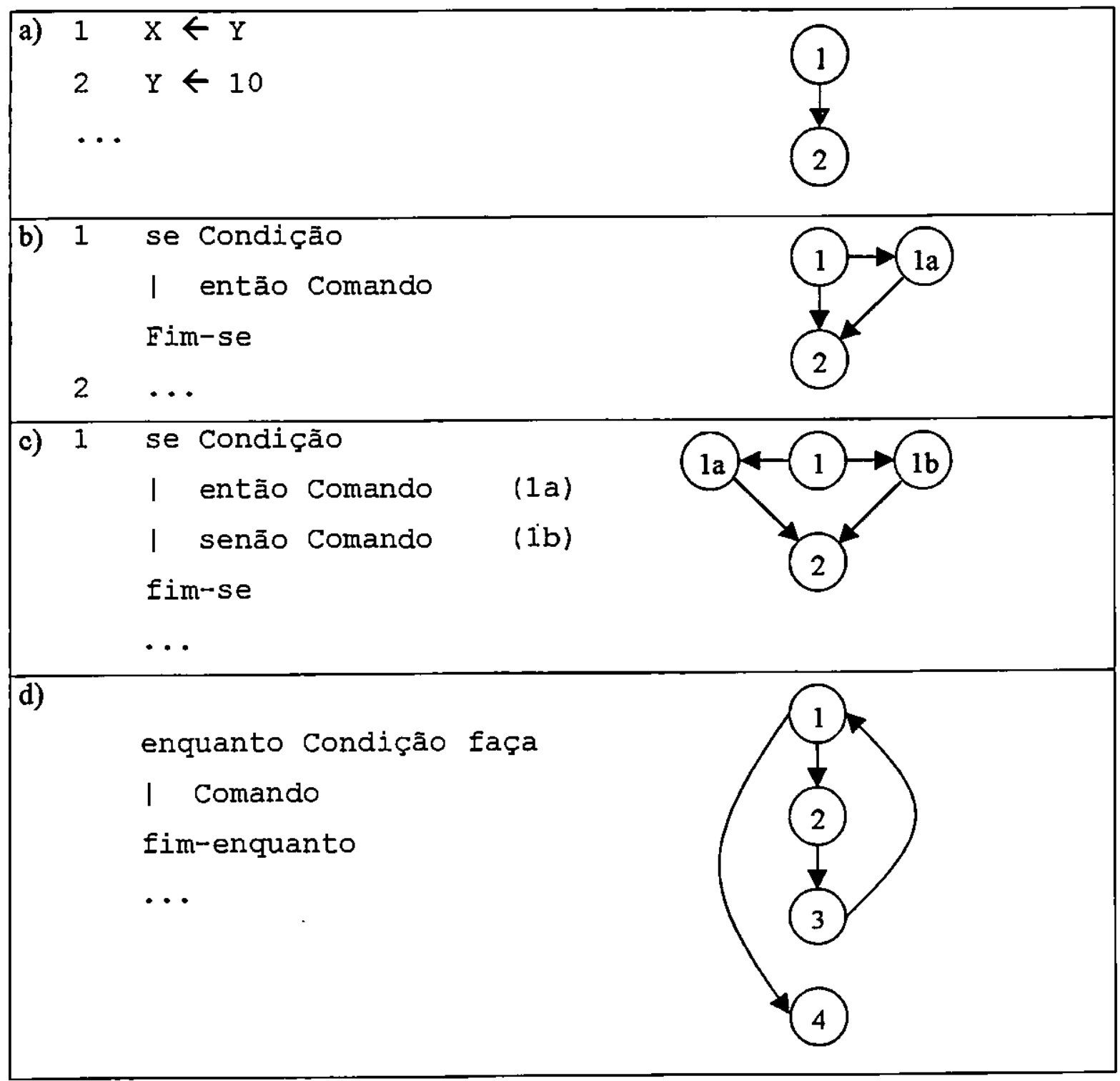




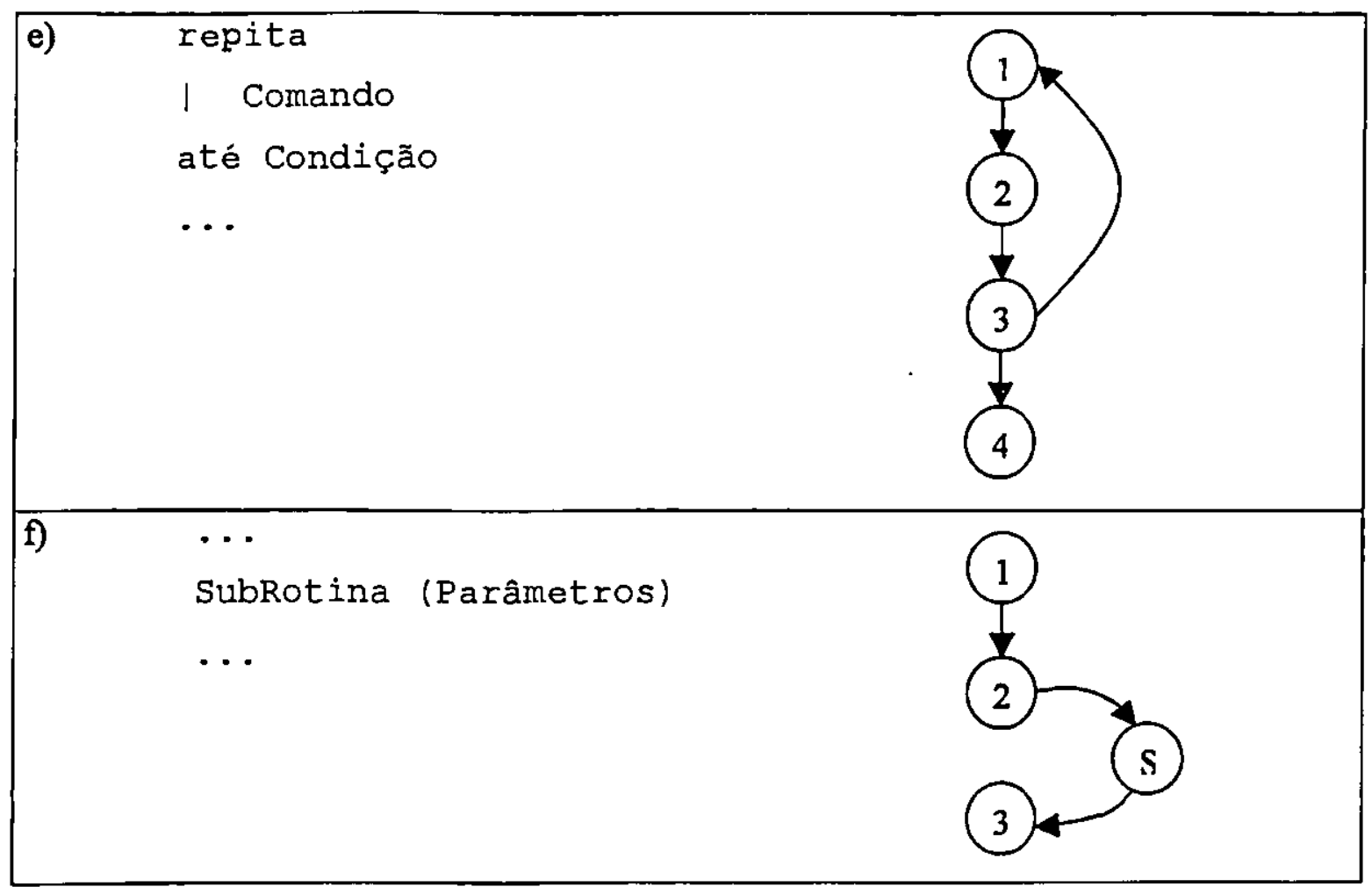

Para exemplificar a criação de um grafo de fluxo de instruções que represente um programa, será utilizado o código fonte apresentado na listagem 6.1. Esse programa usa a biblioteca de troca de mensagens PVM (Paralell Virtual Machine).

\section{Listagem 6.1 - Programa Exemplo para criaçäo de Grafo}

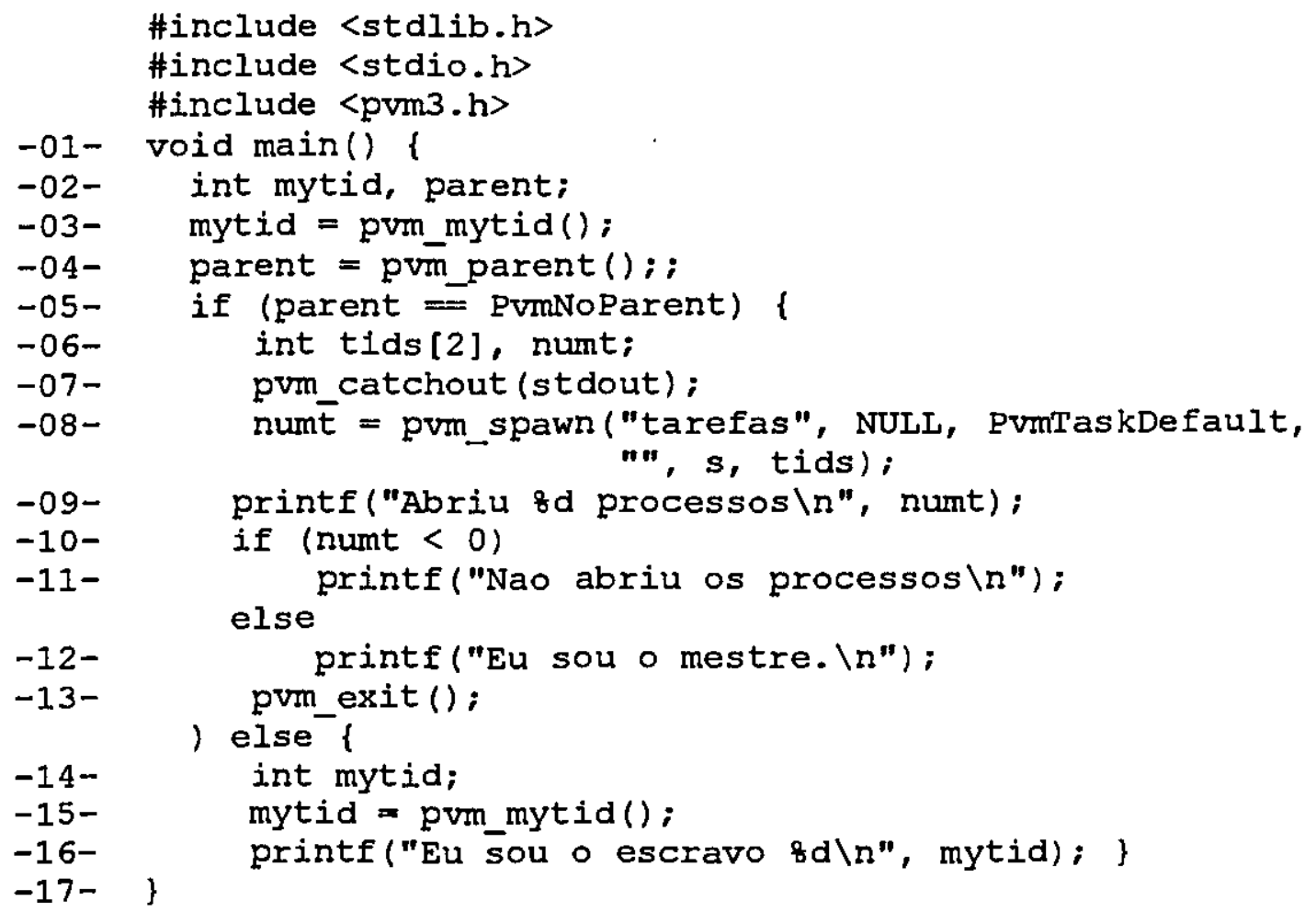


Inicialmente, as linhas do programa fonte são numeradas para facilitar a associação dos nós do grafo resultante com o programa. Cada comando do programa que está sendo depurado, corresponde a um vértice do grafo. A ferramenta analisa o código procurando pelas estruturas básicas apresentadas na tabela 6.1. Parte-se da primeira instrução do programa. Toda as declarações anteriores não são utilizadas para a montagem do grafo de fluxo de instruções. $O$ interesse com a criação desse grafo são os diversos caminhos que o programa pode percorrer durante sua execução. Durante esta análise, a ferramenta vai definindo as relações de dependência entre os nós, ou seja, os fluxos possíveis de execução do programa.

A figura 6.5 apresenta o grafo resultante gerado a partir do programa da listagem 6.1 Nessa representação é possível notar que todos os comandos possuem um nó correspondente no grafo. Porém, representar todos os comandos do programa, produz um grafo de grandes dimensões.

Figura 6.5 - Grafo do Fluxo de Instruçōes da Listagem 6.1

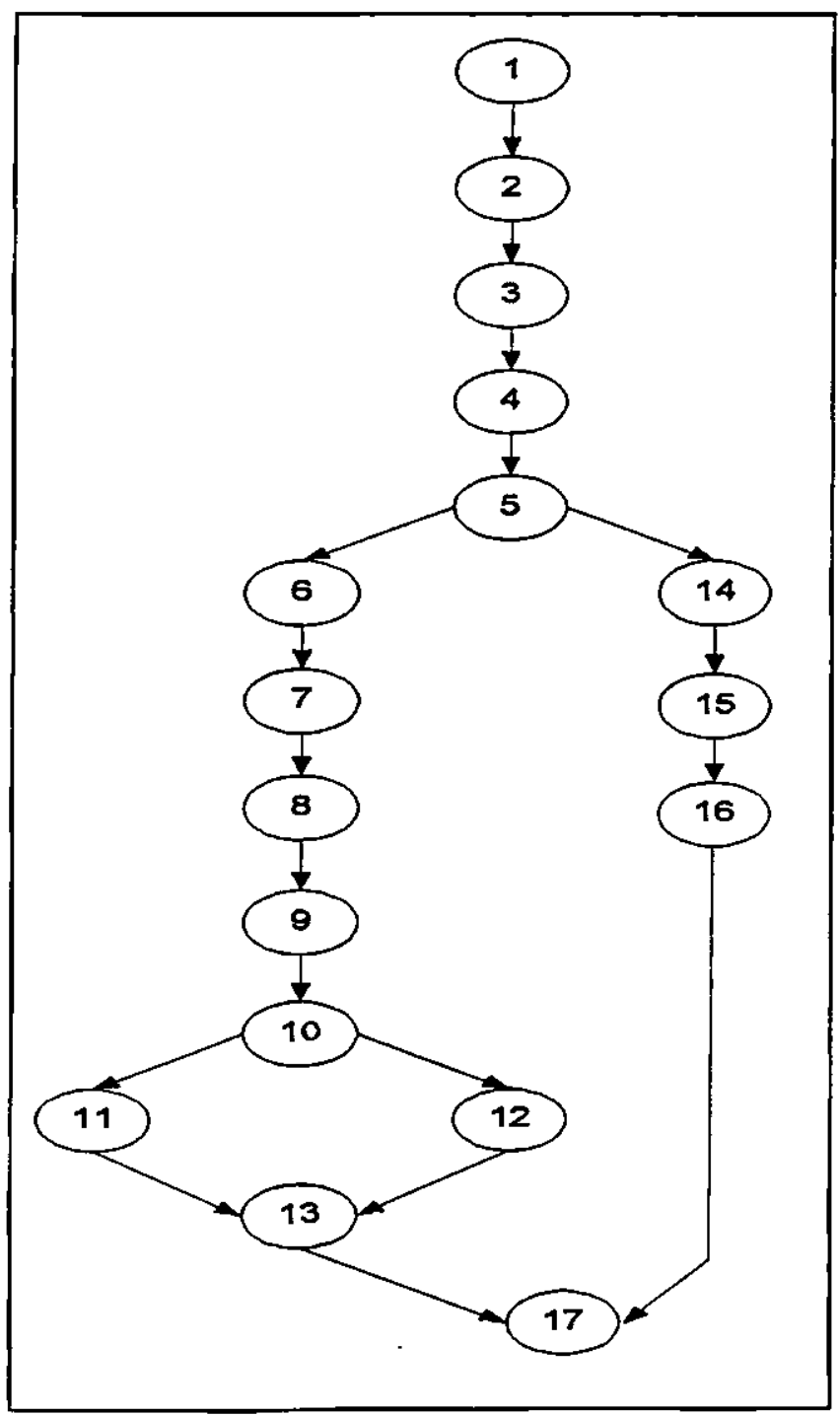


Alguns comandos que não representam instruções paralelas podem ter seus nós * excluídos do grafo, pois essa eliminação não altera a análise que será realizada para localizar os problemas de comunicação e sincronismo dos processos.

\section{Listagem 6.2 - Exemplo de Troca de Mensagens Entre Processos}

\begin{tabular}{|c|c|}
\hline 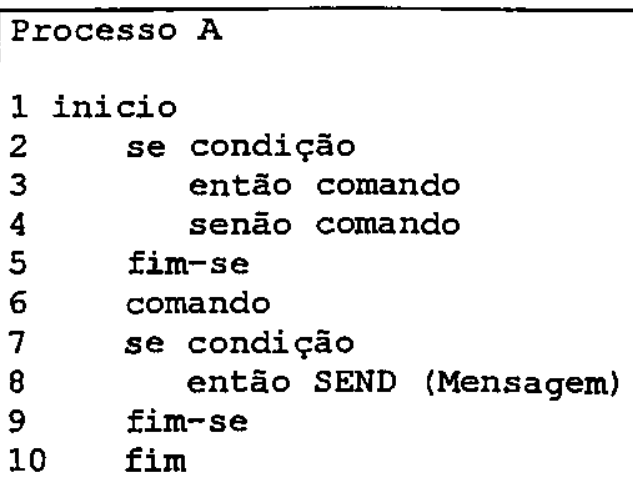 & 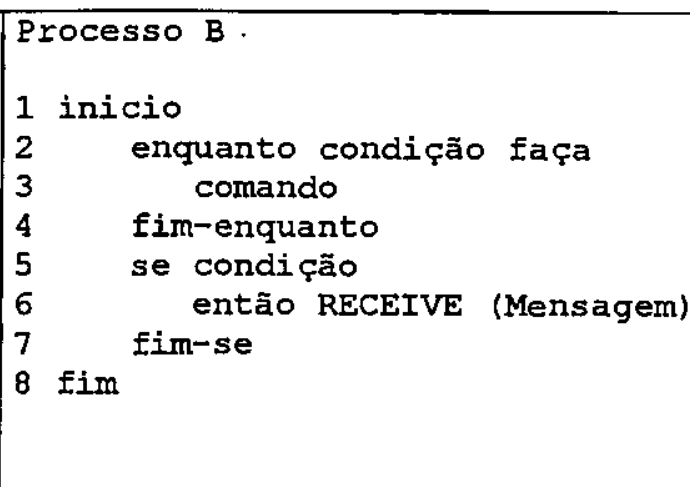 \\
\hline
\end{tabular}

O grafo que será utilizado para a depuração é denominado grafo das comunicações. Para montar o grafo das comunicações, deve-se preservar todos os nós que representam instruções paralelas e os nós que representam mudanças no fluxo do programa, como as estruturas condicionais e as estruturas de repetição, quando existirem instruções paralelas dentro dessas estruturas, ou seja, quando houver caminhos alternativos que não passem pelas instruções paralelas.

Figura 6.6 - Grafo do Fluxo de Instruçōes da Listagem 6.2
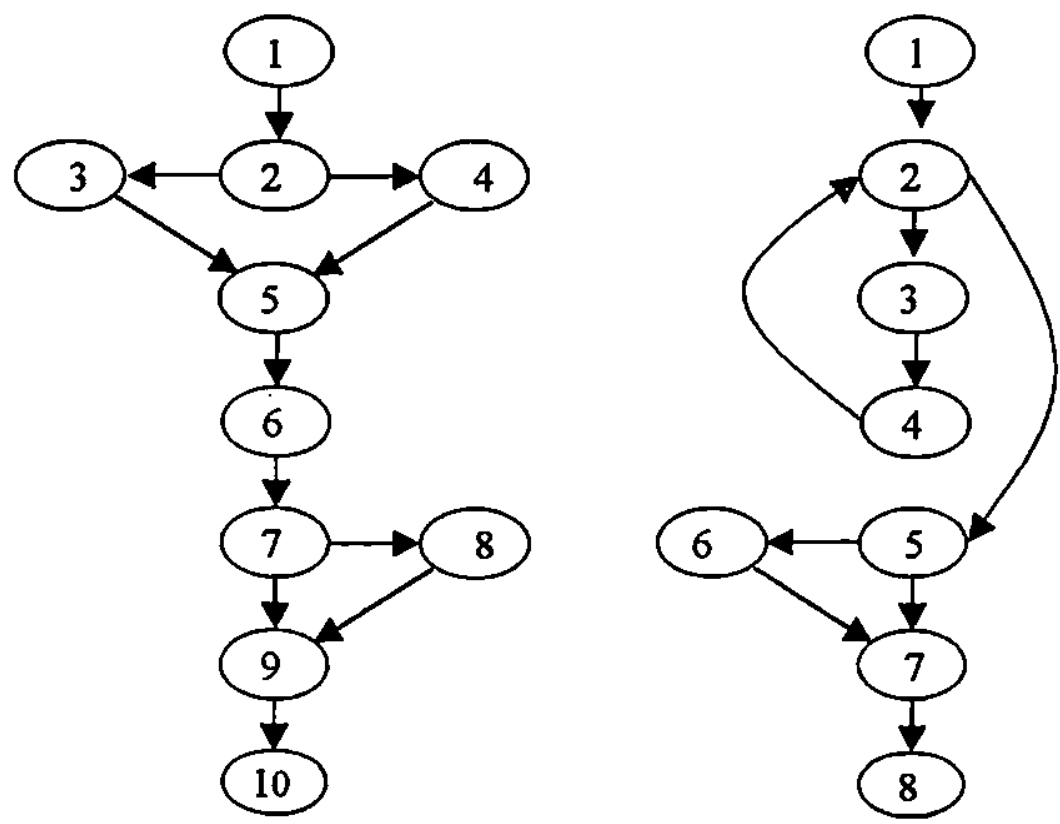
Para se construir o grafo das comunicaçőes entre os processos, utiliza-se os grafos originais do fluxo de instruções de cada tarefa do programa, eliminando os nós que não representam as instruções de comunicação e sincronismo entre os processos e acrescentando os arcos de dependência entre essas instruções. A figura 6.6 apresenta os grafos de instruções que representam os programas da listagem 6.2.

$\mathrm{Na}$ figura 6.7 pode ser visto o grafo de comunicação entre os processos $\mathrm{A}$ e $\mathrm{B}$ da listagem 6.2 depois das modificações nos grafos de fluxo de instruções da figura 6.7. No processo $\mathrm{A}$, os nós $2,3,4,5$ e 6 foram eliminados pois não existe comando paralelo nesse trecho. $\mathrm{O}$ nó 7 foi preservado pois representa um desvio no fluxo de execução do programa e um dos caminhos a partir desse nó possui um comando de envio de mensagem (nó 8). A transformação ocorrida no processo A foi semelhante, os nós 2, 3 e 4 não foram acrescentados no grafo de comunicações por motivos idênticos aos do processo $\mathrm{A}$.

Figura 6.7 - Grafo do Fluxo das Comunicações dos Processos da Listagem 6.2

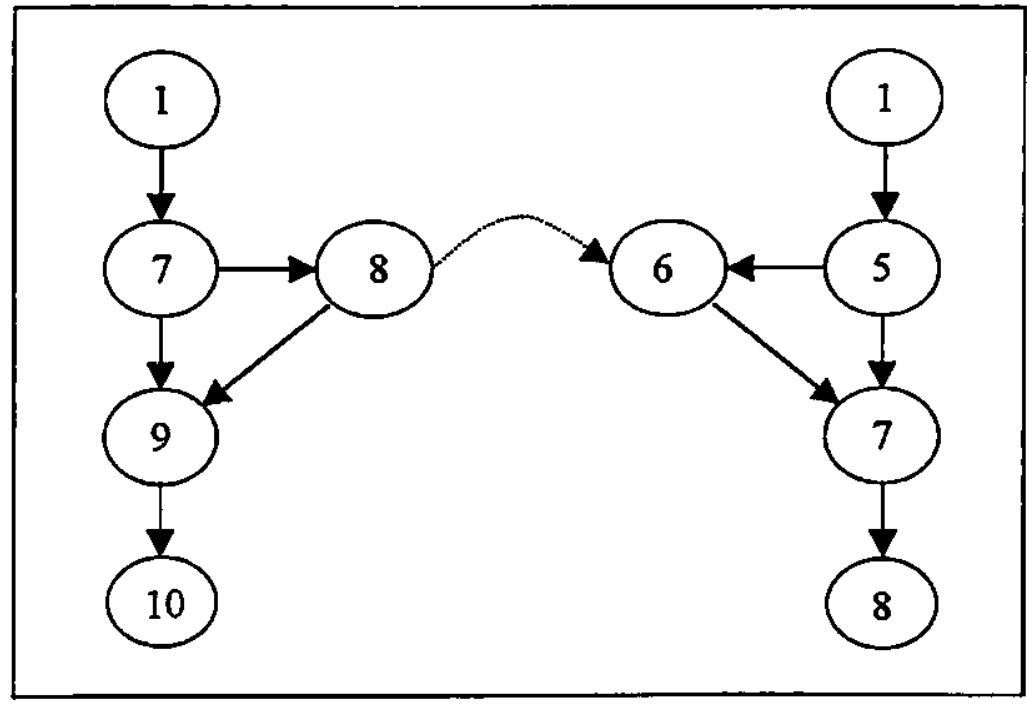

\subsubsection{2 - Descriçäo do Processo 2}

Esse processo é responsável em criar os dois tipos de grafos apresentados na seção anterior: grafos do fluxo de instruções (ou de controle) e grafos de sincronização e o detalhamento de suas funções está representado na figura 6.8 .

O processo 2.1 - Montar os Grafos de Instruções realiza uma análise semântica no programa do usuário, gerando os grafos do fluxo de instruções que representam os caminhos possíveis de serem executados pelo programa. Cada grafo representa a visão do comportamento funcional de uma tarefa. O processo 2.2-Montar Grafos das Comunicações, produz os grafos de sincronização que apresentam as alternativas dos caminhos existentes nas 
comunicações não determinísticas dos processos. Após a geração desses grafos, o processo 2.3 - Localizar Caminhos Possíveis, analisa os grafos para encontrar os caminhos que o programa pode percorrer durante a sua execução. Através desses caminhos, os processos 3,4 e 5 , podem depurar o programa, simulá-lo e interagir com o usuário.

Figura 6.8 - Explosão do Processo 2 - Montar Grafos de Entrada.

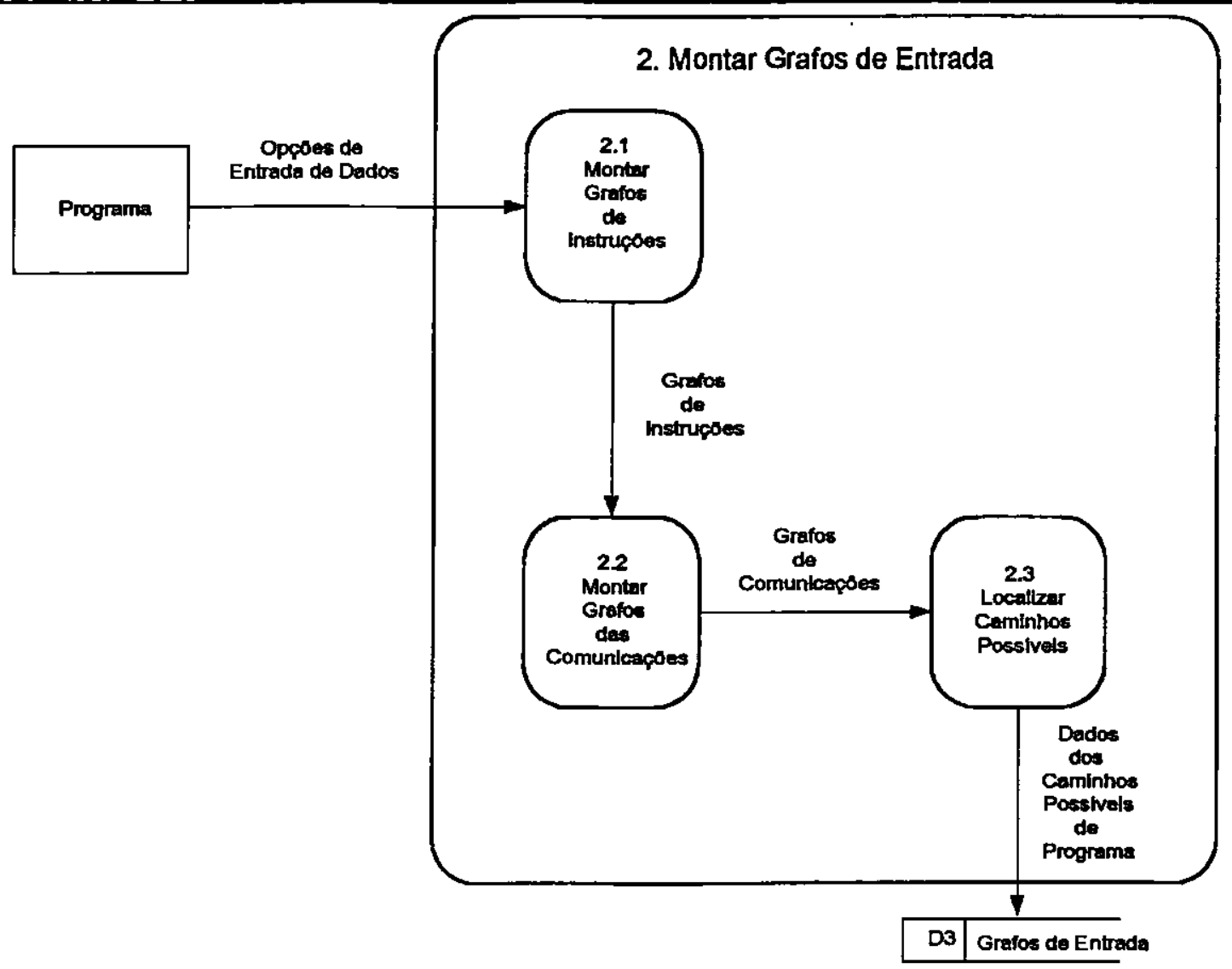

\subsection{3 - Processo 3 - Depurar o Programa}

Esse processo é composto por vários módulos que possuem o objetivo de resolver problemas específicos.

Após a definição dos grafos no processo 2, o processo de depuração caminha pelas rotas possiveis, procurando por problemas que podem estar provocando os erros. Todos os resultados da depuração são armazenados para a utilização das camadas Tutor e de Apresentação.

$\mathrm{O}$ detalhamento do processo 3 pode ser visto na figura 6.9. Ele possui um processo para resolver problemas de deadlock (3.2 - Localizar Situações de Deadlock), um processo para resolver problemas de sincronização e espera infinita (3.3 - Localizar Problemas de Sincronização e Espera Infinita) e um processo que resolve outros tipos de erro como, por exemplo, as análises das partes seqüenciais do programa. O processo 3.1 - Sincronizar Dados 
do Programa Com os Grafos faz o vínculo de cada nó dos grafos criados com as respectivas instruçðes nas tarefas do programa paralelo. 0 processo 3.5 - Armazenar Resultado da Depuração, grava as saidas dos subprocessos responsáveis peia localização de erros e o processo 3.6 - Analisar a Gramulosidade do Programa, procura verificar se a granulosidade de programa paralelo está adequada com a arquitetura.

Figura 6.9 - Explosão do Processo 3 - Depurar o Programa.

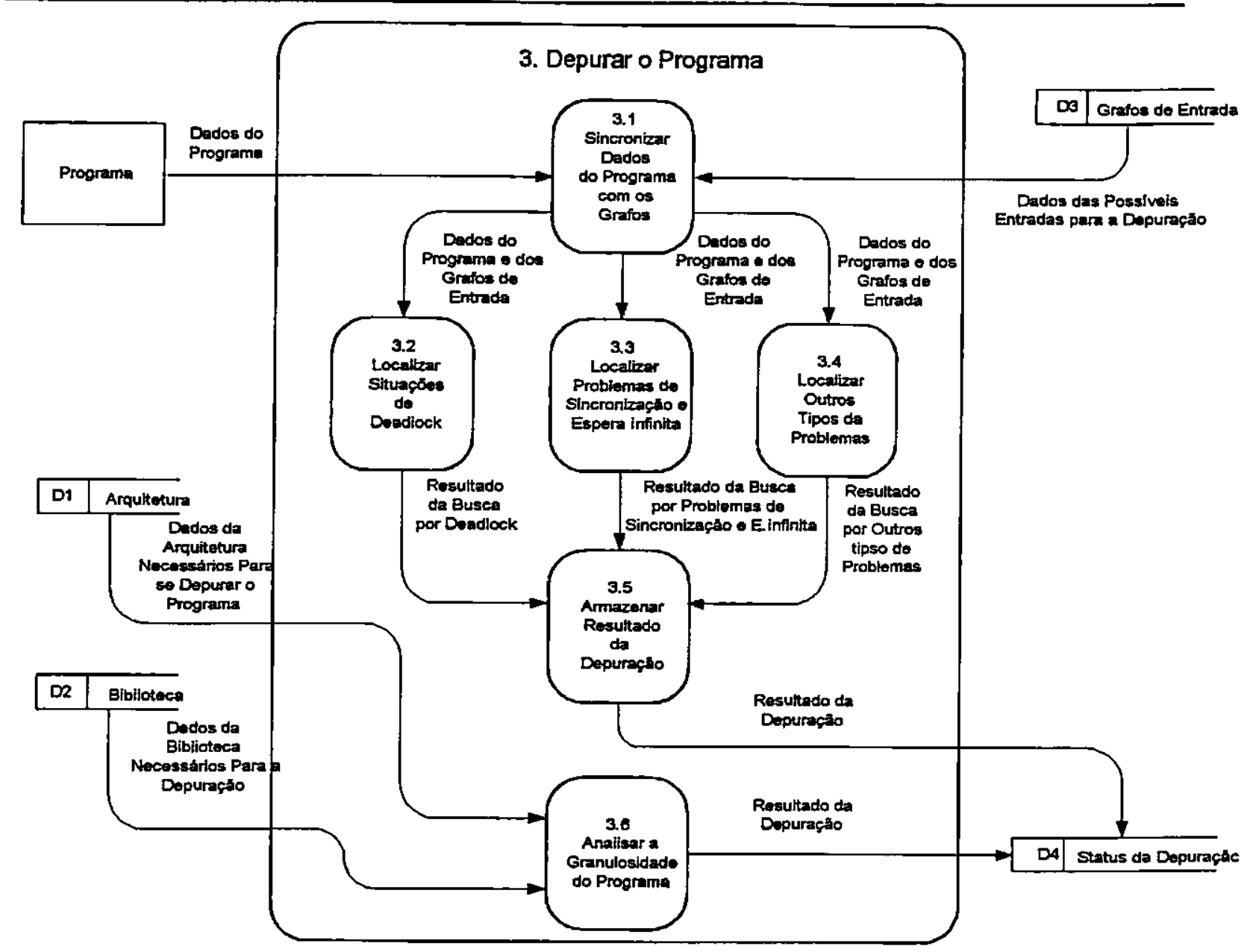

\subsubsection{1 - O Problema da Espera Infinita}

Entre os problemas que surgem com os programas paralelos, a espera infinita é um dos mais comuns. Não chega a caracterizar um problema de deadlock, pois não existe um laço contendo vários processos bloqueados, mas a existência de um processo esperando por uma mensagem que nunca ocorrerá independente dos outros processos estarem bloqueados ou não.

Para localizar a existência de caminhos que levem um ou mais processos de um programa paralelo a um estado de espera infinita é necessário verificar nos grafos de comunicação criados no processo 2 , a existência de caminhos alternativos que não passem pela comunicação. É importante lembrar que os grafos de comunicação não possuem a mesma 
quantidade de nós que os grafos originais do programa (grafos de fluxo de instruções) e mantém apenas os nós que definem as comunicações entre os processos. A existência de caminhos que não passem pelos arcos da comunicação indica a existência de caminhos que podem provocar o problema da espera infinita.

A figura 6.7 apresenta um grafo de comunicação e sincronismo entre os processos, com a possibilidade de ocorrer o problema de espera infinita, durante a execução do programa. Se o processo A seguir o caminho 1-7-9-10 e o processo B seguir o caminho 1-5-6, esse processo ficará esperando por um evento que nunca ocorrerá. Outra situação indesejável pode acontecer se o processo A seguir o caminho 1-7-8-9-10 e enviar uma mensagem e o processo B seguir o caminho 1-5-7-8 que não espera por mensagem. Se o envio for bloqueante o processo A entrará em espera infinita, caso contrário uma mensagem será perdida.

Listagem 6.3 - Exemplo de Processos Livres do Problema de Espera Infinita

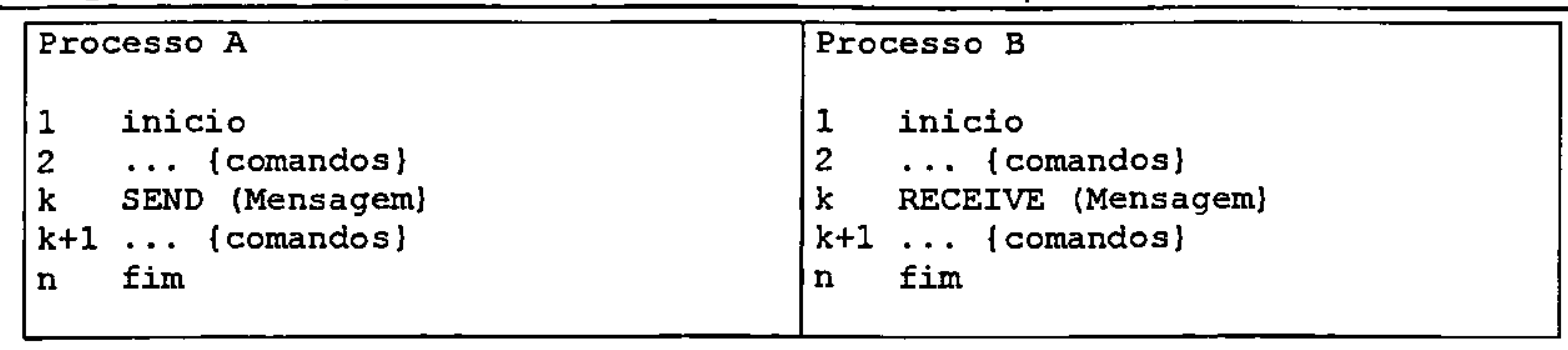

A dificuldade nessa análise é verificar o resultado das condições representadas pelos nós 7 no processo A e 5 no processo B. Para isso é preciso realizar uma análise do histórico das variáveis contidas na condição de seleção. É possível verificar a probabilidade dos processos entrarem em espera infinita atràvés desse histórico, transformando todas as condições que compõem o caminho que se deseja analisar em equações [Gupta et al., 1998]. $O$ conjunto dessas equações pode ser resolvido através de um sistema de equações. Se o sistema possuir solução, existirão valores que as variáveis poderāo receber e que forçará a passagem pelo caminho com problema. Mas, ainda assim, é muito dificil encontrar o conjunto completo de valores das entradas do programa que levam a um resultado indesejado.

$O$ grafo da figura 6.10 representa o programa da listagem 6.3. Nele pode-se verificar a impossibilidade de ocorrer o problema da espera infinita. Essa situação só irá ocorrer na prática se a mensagem enviada for perdida no meio de comunicação, situação que não será tratada por esta ferramenta. 
Figura 6.10 - Grafo do Fluxo das Comunicações dos Processos da Listagem 6.3

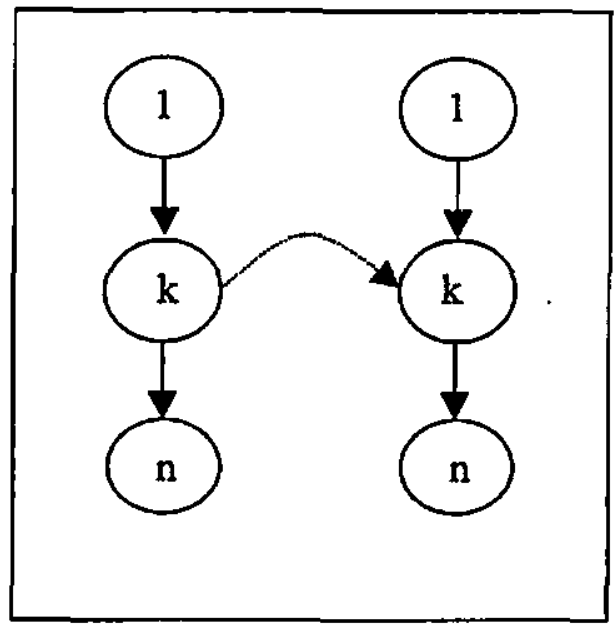

\subsubsection{2 - Deadlock}

Para encontrar a ocorrência de deadlock é necessário percorrer os grafos de comunicação que compõem o programa paralelo procurando pela existência de ciclos. A existência de ciclos define a dependência das mensagens que trafegam entre as tarefas.

O objetivo da ferramenta é localizar a ocorrência de deadlock interno. A ferramenta pode através do processo 5 , sugerir mudanças no programa do usuário para gerenciar a alocação de vários recursos, utilizando métodos como o apresentado em [Tanenbaum, 1992] denominado algoritmo do banqueiro, que libera os recursos somente quando esses recursos não causarem deadlock, como em um empréstimo bancário. A listagem 6.4 apresenta três tarefas que se encontram em deadlock como pode ser visto na figura 6.11 , através do ciclo representado pelos arcos da comunicação. Durante a interação com o usuário, a ferramenta deverá propor mudanças no código para resolver o problema como, por exemplo, a inversão do nó $k$ com o nó $l$ na tarefa A, eliminando o ciclo e consequientemente o deadlock. Se essa mudança não for possível, devido à lógica do programa, então a ferramenta irá sugerir a troca do comando para um receive não bloqueante.

\section{Listagem 6.4 - Processos em Deadiock}

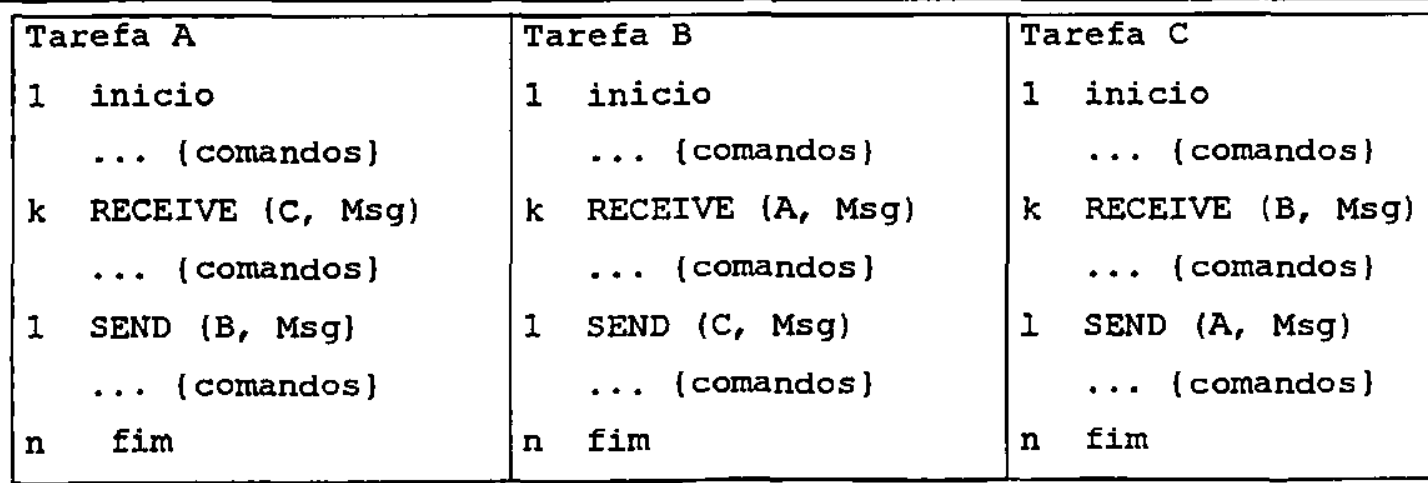




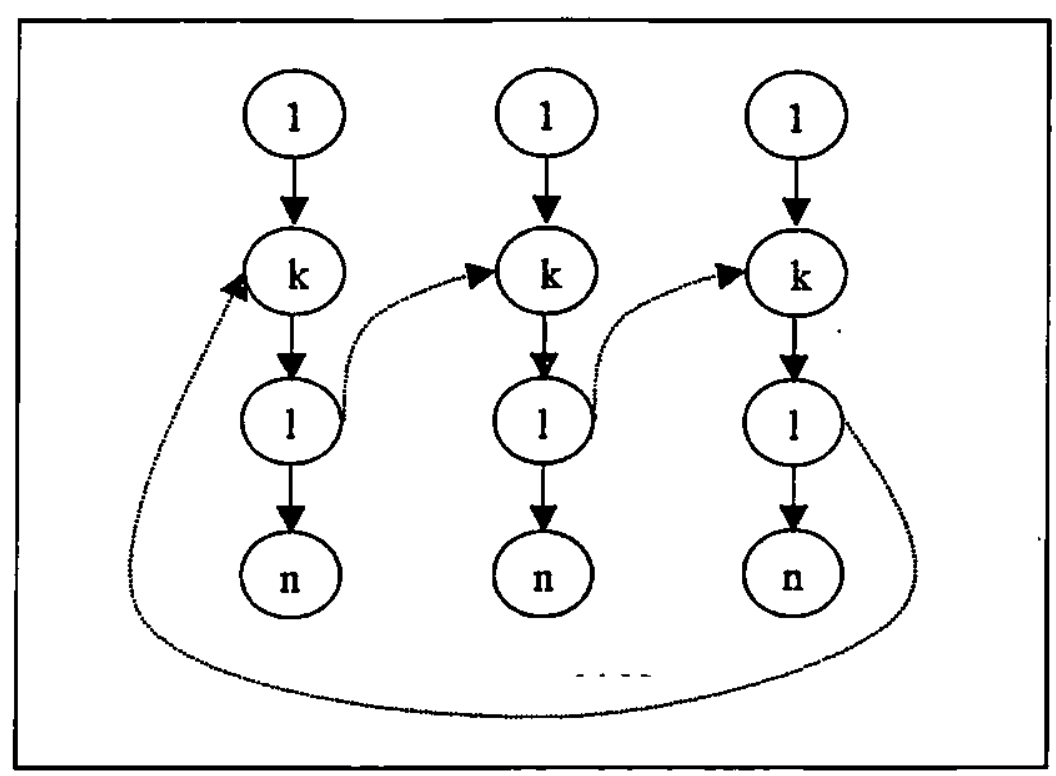

\subsection{4 - Processo 4 - Criar Ambiente Tutor}

O processo 4 - Criar Ambiente Tutor, através das informações que trafegam no sistema, permite o desenvolvimento de um grande número de aplicações. É possível a criação de um ambiente tutor inteligente interagindo com uma fonte de conhecimento que poderá “aprender" o estilo de programação do usuário para possibilitar uma programação cada vez mais eficiente.

A criação de um ambiente tutor na ferramenta privilegia a mudança de paradigma no processo de ensino-aprendizagem: o modelo tradicional, que centraliza a atenção no professor, para o modelo centrado no aluno e com base em "aprender a aprender". Com a análise dos próprios erros e com o amparo do ambiente tutor, o usuário passa a dominar as técnicas e entende o processo a fim de que possa generalizar um aprendizado para novas situações.

É importante notar que a entidade externa "Fonte de Conhecimento" representa um sistema à parte. Trata dos aspectos inerentes aos Sistemas Tutores, ou seja, os módulos do domínio do conhecimento, o módulo tutor e o módulo de controle. Esse processo (Criar Ambiente Tutor) é o responsável pela comunicação entre o usuário, às informações que trafegam neste sistema (Depurador) e pelo sistema tutor, representando parte do módulo da interface com o usuário.

O motivo de se localizar a arquitetura do Tutor fora da fronteira de definição do sistema ocorre porque o Processo 4 realiza a mediação das informações que trafegam no sistema de depuração com a entidade externa Conhecimento. Essa independência toma 
flexível a evolução dos dois sistemas (ambiente de depuração e sistema tutor) sem um afetar o outro. Como o modelo do sistema tutor irá possuir a sua maior parte implementada fora desta ferramenta, esse processo não será explodido.

\subsection{5 - Processo 5 - Montar Grafos de Simulação}

A simulação será utilizada para criar um ambiente onde o usuário percebe o comportamento do programa sem a necessidade de executá-lo. Existem algumas vantagens em simular o comportamento de um programa paralelo em um ambiente de depuração. Além da visão global do programa, a simulação permite verificar processos em estado de espera infinita ou a presença de deadlock. É muito dificil para um usuário iniciante da programação paralela visualizar o comportamento de um programa paralelo que possui tarefas que estão executando em processadores diferentes e que em muitos casos (por exemplo, em sistemas distribuídos) estão fisicamente distantes. É comum durante o aprendizado da programação paralela, a criação de processos que não executam da maneira esperada e que entram em espera infinita. Várias vezes, quando ocorrem esses erros durante a execução do programa, é dificil perceber qual processo está parado e em que ponto.

A simulação gerada por esse processo permite ao usuário controlar o comportamento do programa, percebendo a dependência que existe entre as tarefas. Além disso, é possivel modificar o "desenho" do grafo no próprio ambiente para verificar o comportamento do sistema, ou seja, é possivel propor mudanças no comportamento do programa para verificar o resultado antes mesmo da correção do programa. Outra relevância é a possibilidade de análise de um problema sem a existência de um programa paralelo implementado. Se o grafo construído diretamente no ambiente comportar-se corretamente é possivel a utilização de ferramentas que geram o arcabouço da aplicação [Branco, 1999].

Durante a simulação, cada tarefa que compõe o programa paralelo é representada por um grafo. Na simulação é possível criar linhas de controle (threads) para a simulação de cada grafo, isto possibilita a representação da diferença de desempenho dos processadores em ambientes heterogêneos através da atribuição de prioridades às linhas de controle proporcionais as diferenças reais do poder de processamento das CPUs que compõem o ambiente onde o programa paralelo será executado.

A estrutura da ferramenta possui uma característica interessante que é a possibilidade de analisar o nível de paralelização utilizado pelo usuário, através dos grafos de fluxos do programa. É possivel analisar as precedências das instruções e verificar o que pode ser melhorado no código do usuário. Através da análise de como os dados do programa se 
relacionam e como as estruturas do programa estão encadeadas é possivel identificar os trechos possíveis de paralelização. $O$ processo permite após a paralelização comparar a eficiência alcançada.

O detalhamento desse processo pode ser visto através da figura 6.12. O processo 5.1 Buscar Dados da Arquitetura e Biblioteca é o responsável de configurar o ambiente para simular os grafos com parâmetros próximos da arquitetura real. O processo 5.2 - Criar Threads Para Cada Grafo inicializa os subprocessos que irão simular o fluxo de execução. 0 processo 5.3 - Definir Caminho interage com o usuário para a escolha de um dos caminhos encontrados pelo processo 2.

Figura 6.12 - Explosão do Processo 5 - Montar Grafos de Simulação

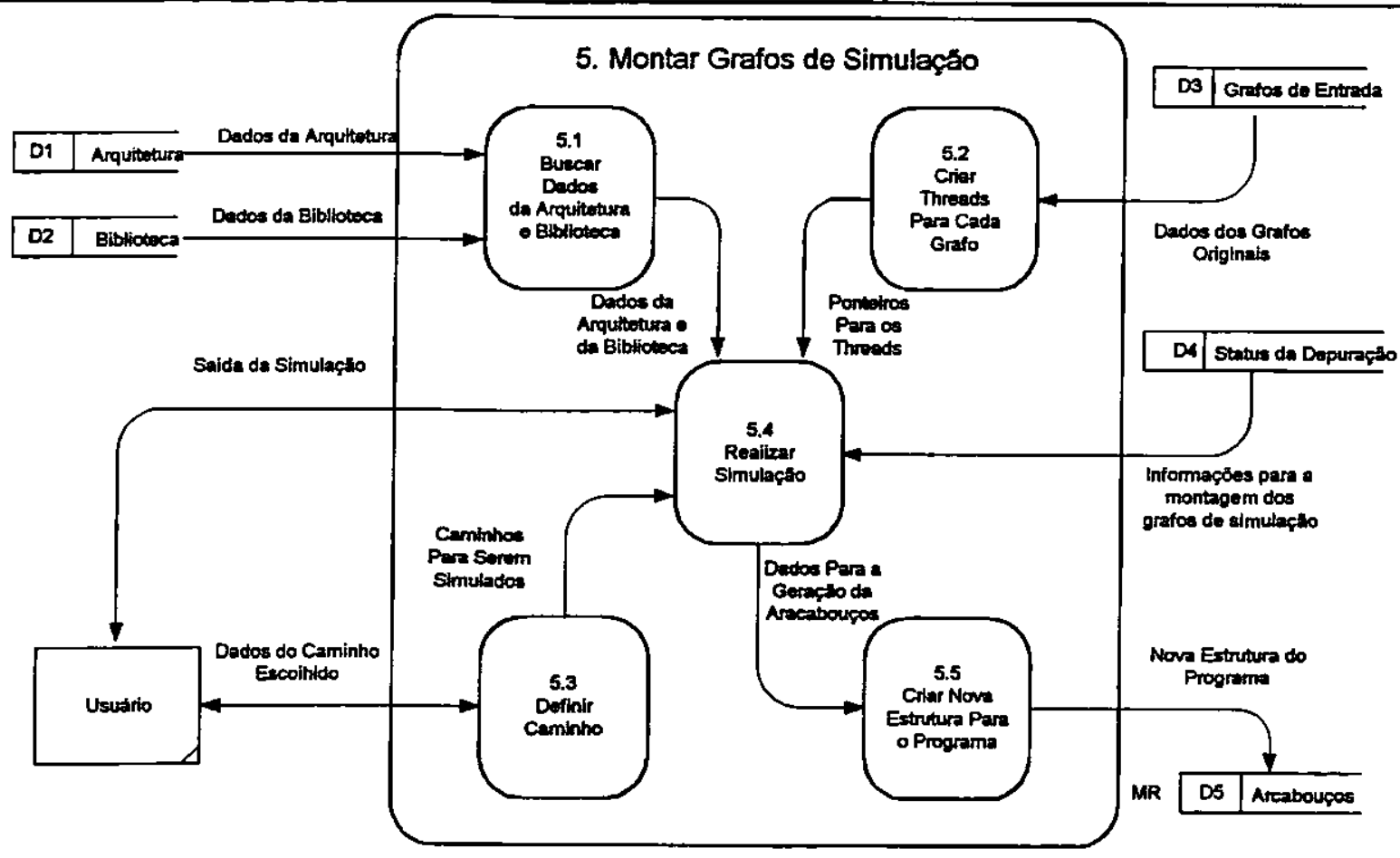

Após essas definições, o processo 5.4 - Realizar a Simulação coloca cada linha de controle (thread) para executar. Se o usuário desejar, é possivel ainda, gerar o protocolo de saída para a montagem do arcabouço de uma nova aplicação.

O funcionamento desse processo pode ser melhor compreendido através das explicações contidas no próximo capitulo que descreve um protótipo da ferramenta de depuração de programas paralelos. 


\section{2 - Considerações Finais}

$\mathrm{Na}$ especificação do projeto dessa ferramenta teve-se o cuidado de não analisar casos particulares, ou seja, as estruturas não pertencem a uma determinada linguagem. Foi objetivo criar uma especificação formal de como deve ser uma ferramenta para auxilio na depuração de programas paralelos contendo um ambiente de aprendizagem de programação paralela. Esse projeto possibilita a implementação em diversas linguagens para programação paralela voltada a ambientes em que a troca de mensagem seja usada como mecanismo de comunicação e sincronização de processos. 


\section{Capítulo 7 \\ O Desenvolvimento de Um Protótipo}

O objetivo na criação do protótipo descrito nesse capítulo é demonstrar a aplicabilidade do projeto. Uma vez desenvolvido, o protótipo permite visualizar as tarefas que compõem a ferramenta. Além disso, é possível visualizar as dificuldades que serão enfrentadas durante a construção da ferramenta vinculada a uma linguagem ou ambiente de programação paralela específico.

A maior vantagem proporcionada pela criação de um protótipo é avaliar o potencial do sistema e permitir mudanças durante o projeto da ferramenta. Posteriormente, durante a implementação de uma versão final, em uma determinada linguagem, o protótipo pode ser reutilizado.

Outro aspecto importante é a utilização do protótipo como projeto de interface da ferramenta. É possível verificar a facilidade com que os usuários interagem com o ambiente.

A interface com o usuário é o mecanismo por meio do qual se estabelece um diálogo entre o programa e o ser humano [Pressman, 1992]. A interface proposta nesse trabalho é bastante intuitiva, como pode ser visto na figura 7.1.

Nas seções desse capítulo serão abordados os assuntos pertinentes à criação desse protótipo $\mathrm{e}$ as possíveis dificuldades de implementação que serão encontradas no desenvolvimento de uma versão final da ferramenta.

O protótipo foi desenvolvido com a utilização da linguagem de programação Delphi. Apesar de não ser uma linguagem explicitamente paralela, o Delphi atende aos objetivos propostos para esse protótipo. Em primeiro lugar, o Delphi é uma linguagem orientada a objetos, o que permite uma boa modularização do código, além de ser uma versão RAD (Rapid Application Development - Desenvolvimento Rápido de Aplicativos) do Turbo Pascal 
para Windows. Em ambientes RAD, o projetista define o que quer ver e o ambiente de programação cria o código necessário para realizar isso. Outro fator importante é a possibilidade de se criar threads (linhas de controle). Durante a execução, o thread primário de um processo pode criar outros threads (e também outros processos), os quais, por sua vez, também podem criar mais threads ou mais processos. Dessa forma, o sistema operacional consegue escalonar o uso do processador entre os diversos threads, permitindo a concorrência entre os threads pertencentes a um ou vários processos. Mais informações sobre essa linguagem podem ser encontradas em [Carvalho, 1998], [Norton e Mueller, 1997] e [Cantú, 1999].

Figura 7.1 - Tela Principal do Ambiente de Depuração de Programas Paralelos

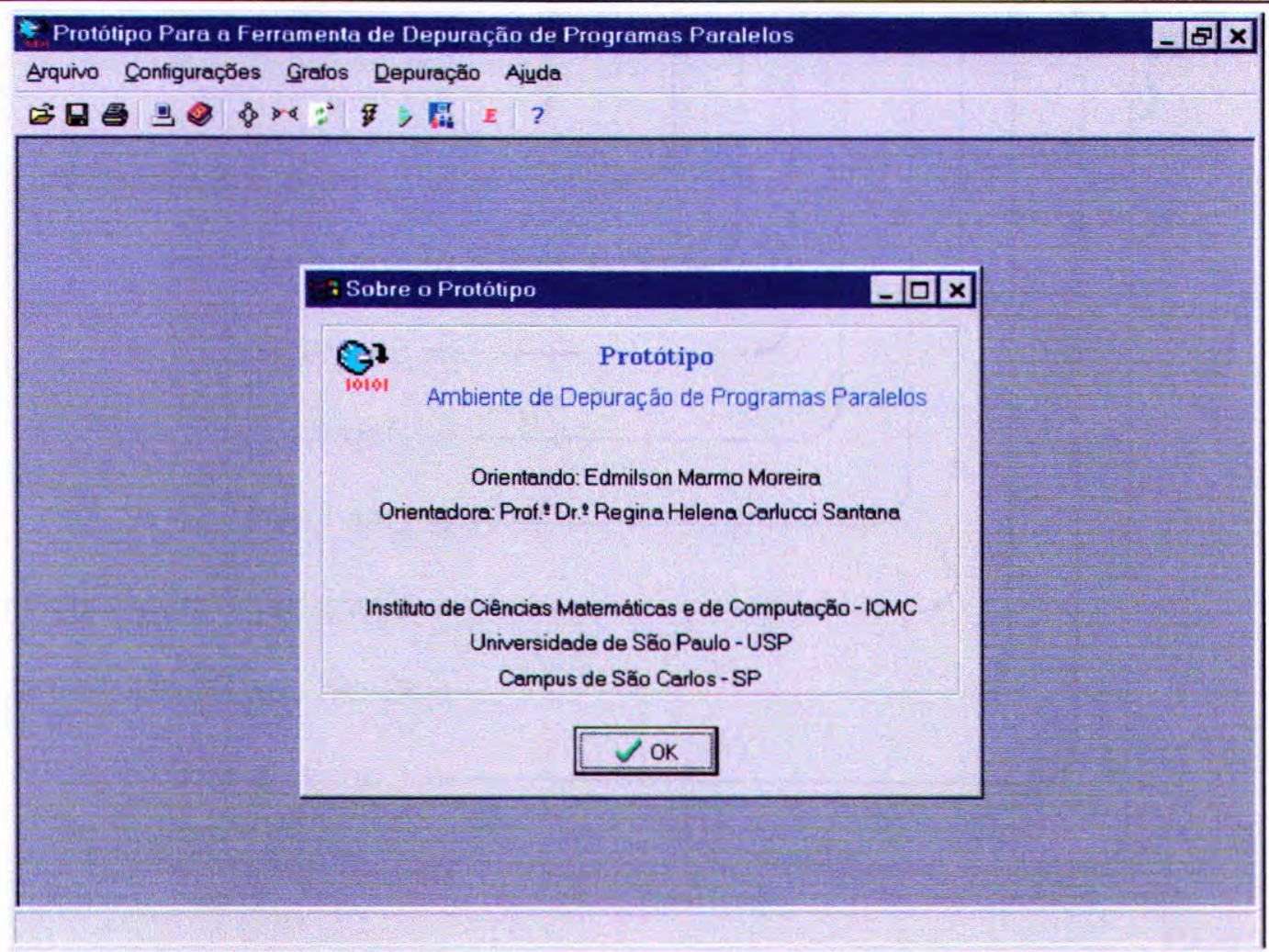

\section{1 - O Ambiente}

A Interface básica do protótipo é dividida em duas partes: o Menu de opções da ferramenta e a área de trabalho que irá apresentar as diversas janelas para as simulações além de permitir a edição dos algoritmos paralelos.

A ferramenta desenvolvida deve expressar com clareza as camadas especificadas em seu projeto e os processos que surgiram no modelo apresentado no capítulo anterior. Isto pode ser facilmente identificado nas opções que o protótipo oferece (figura 7.2). No item de Configurações é possível atualizar os dados correspondentes às camadas de Arquitetura e da 
Biblioteca. O item Grafos está dividido em três opções que permitem criar os grafos de fluxo de instruções, os grafos de comunicação e gerar os caminhos possíveis de serem percorridos pelo programa, além de visualizar os estados dos processos que estiverem sendo simulados. $\mathrm{O}$ item Depuração possui as opções para se depurar o programa, simulá-lo ou acionar o ambiente tutor. Através da opção de Arquivo é possível abrir um programa ou editá-lo, além das opções de salvar e imprimir os arquivos de programa, os grafos e os caminhos correspondentes.

Figura 7.2 - As principais Funções do Ambiente de Depuração de Programas Paralelos.

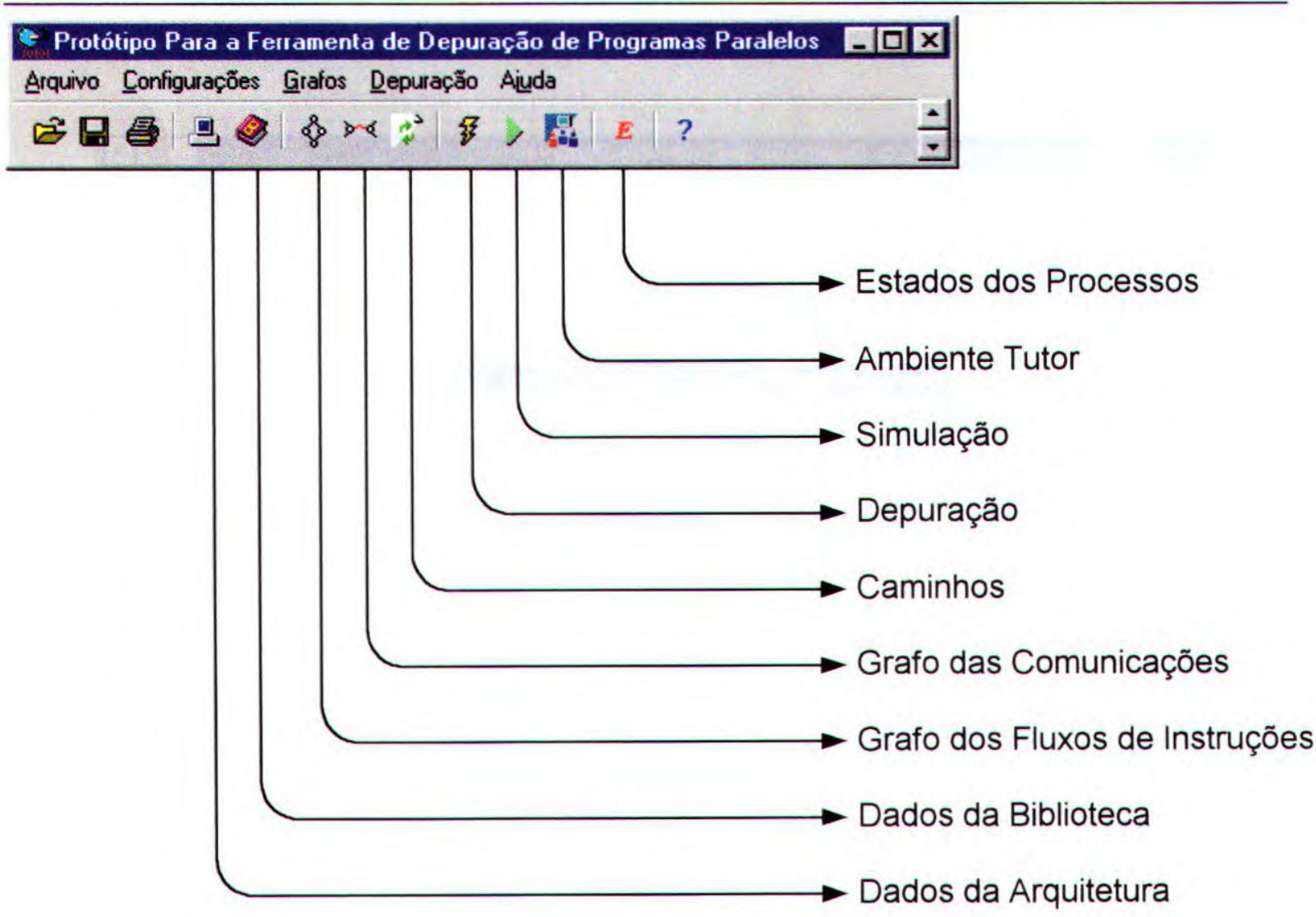

As telas para entrada de dados das informações definidas no capítulo 6, referente às camadas de Arquitetura e Biblioteca, podem ser vistas na figura 7.3.

A próxima seção descreve as características das estruturas responsáveis pela definição dos grafos utilizados no protótipo. 
Figura 7.3 - Entrada dos Dados da Arquitetura e da Biblioteca.

\section{Arquitetura}

Arquitetura | Elementos de Processamento | Memória | Barramento |

Arquitetura de Execup̧a do Programa: Selecione a Arquitetur

Periféricos: Selecione os Tipos de Períéricos

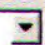

Informaçōes Adicionais (Ambiente Heterogêneo):

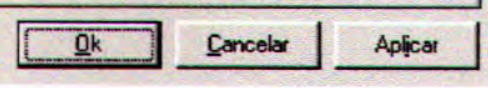

Arquitetura

Arquitetura | Elementos de Processamento Memória | Baramento|

Tipo de Memória

C Memória Fortemente Acoplada C Memória Fracamente Acoplada

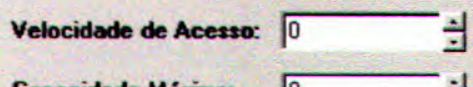

Capacidade Máximar $\longdiv { 0 }$ जे

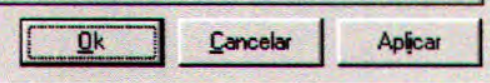

: Biblioteca

Linguagem Utilizada: Selecione a Linguagem Utízada

Biblioteca:

Seleione a Bblioteca

Sistema Operacionat: Seleione o Sistema Operacional v

Quantidade de Tarefas: 0

Arquitetura do Sistema

C SPMD (Simple Program Mulliple Data)

c MPMD (Multiple Program Muitiple Dała)

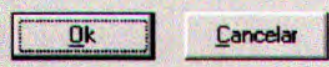

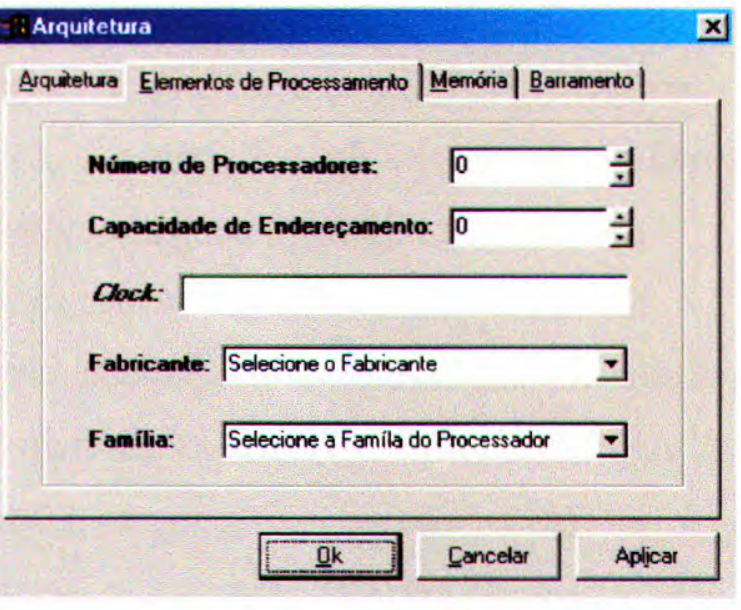

x]

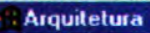

$\times$

Arquitetura| Elementos de Processamento | Memória Barramento |

Tipo de Barramento: Selecione o Tipo de Barramento

Interface Utilizada: Selecione a Interface Utilizada

Meios de Transmissāo: Selecione o Meio de Transmissão

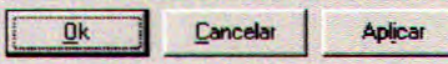

\section{2 - Representando um Algoritmo Através de Um Grafo}

Existem várias formas de armazenar um grafo em um computador. Uma representação bastante comum é através da utilização de matrizes.

Supondo que um grafo possui $n$ vértices numerados $n_{l}, n_{2}, \ldots, n_{n}$. Essa numeração define uma ordenação arbitrária no conjunto de vértices. É importante observar que esse tipo de conjunto é chamado de um conjunto ordenado. No entanto, isso é feito com o único intuito 
de identificar os vértices - não há qualquer relevância no fato de um vértice aparecer antes de outro na ordenação. A partir dos vértices ordenados, é possível-formar uma matriz $n \times \boldsymbol{x} n$ onde o elemento $i, j$ é o número de arestas entre os vértices $n_{i}$ e $n_{j}$. Essa matriz é chamada de matriz de adjacências do grafo com relação à ordenação. Portanto,

$a_{i j}=p$ onde existem $p$ arcos partindo do vértice $n_{i}$ para o vértice $n_{j}$

Estão sendo considerados apenas os grafos dirigidos (dígrafos) devido a sua relevância para este trabalho. A figura 7.4 apresenta um grafo e a matriz de adjacência correspondente. É uma matriz $4 \times 4$, pois o grafo possui quatro nós. 0 elemento 1,1 é 0 devido ao fato de não haver um laço no vértice 1 . O elemento 1,2 (primeira linha, segunda coluna) é 1 porque existe apenas uma aresta entre os vértices 1 e 2 , e assim por diante.

Figura 7.4 - Exemplo de Grafo e Sua Representaçăo através de uma Matriz de Adjacência.

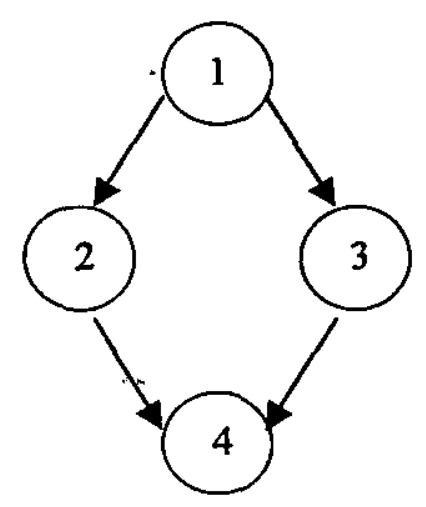

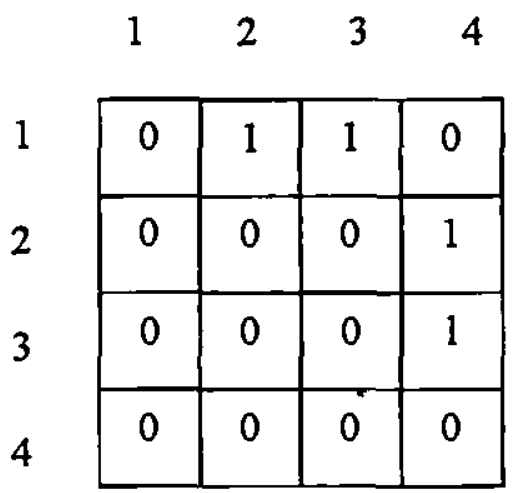

O grafo apresentado na figura 7.4 produziu uma matriz esparsa, devido aos' poucos arcos que existem no grafo. Os grafos que representam um programa têm relativamente poucas arestas. Esses grafos têm matrizes de adjacências esparsas; isto é, suas matrizes de adjacências contêm muito zeros. Supondo um programa $\operatorname{com} n$ instruções, produzindo um grafo com $n$ vértices, serão necessários $n^{2}$ elementos da matriz de adjacências.

Um grafo com relativamente poucas arestas pode ser representado mais eficientemente, armazenando apenas os elementos não-nulos de sua matriz de adjacências. Essa representação consiste em uma lista para cada vértice de todos os vértices adjacentes a ele. Usam-se ponteiros para permitir que se caminhe de um elemento da lista para o seguinte. Esse tipo de estrutura de dados é chamado de lista encadeada. [Gersting, 1993]

Para encontrar-se todos os vértices adjacentes a $\boldsymbol{n}_{\boldsymbol{i}}$ é preciso varrer a lista referente a $\boldsymbol{n}_{\boldsymbol{i}}$, que deve ter menos elementos que os $\boldsymbol{n}$ que seriam examinados na matriz de adjacências.

A maior dificuldade encontrada nessa representação está relacionada com a necessidade de determinar se um vértice $n_{j}$ em particular é adjacente ao vértice $n_{i}$. Para isso, 
será preciso percorrer toda a lista encadeada de $n_{i}$.

Como exemplo, a figura 7.5 apresenta o mesmo grafo da figura 7.4 e a respectiva lista de adjacências contendo um vetor de quatro elementos de ponteiros, um para cada vértice. $O$ ponteiro de cada vértice aponta para um vértice adjacente, que aponta para outro vértice adjacente, e assim por diante, até o último nó que não aponta para nenhum nó. $O$ nó 4 não aponta para nenhum outro nó.

Figura 7.5 - Exemplo de Grafo e Lista de Adjacência correspondente.
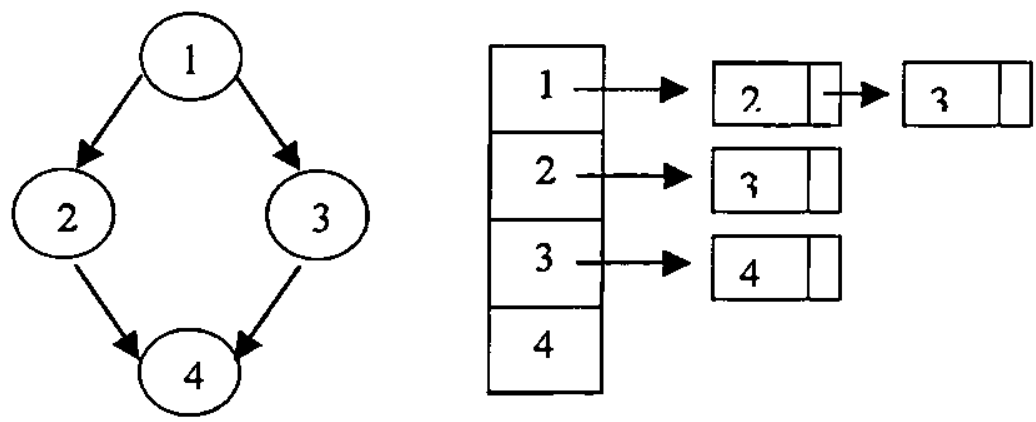

$\mathrm{Na}$ listagem 7.1 pode-se observar as estruturas existentes no protótipo, responsáveis pela representação dos grafos. Inicialmente é definido um ponteiro para um nó (PonteiroNo). O nó é um registro que armazena um campo de informação, ou seja, o número da linha que o nó representa e um campo de ligação que é o ponteiro para o próximo nó adjacente. $O$ tipo enumerado Estado foi definido para representar o estado em que se encontra um programa em simulação. As opções são: Exec para quando o processo estiver em execução, send quando o processo estiver bloqueado para enviar uma mensagem, Receiv quando o processo estiver bloqueado aguardando por uma mensagem e Dead quando o processo encerrou a sua execução. Cada objeto da classe de objetos TLista pode manipular uma lista encadeada. Essa classe possui os atributos Comeco, que é um ponteiro para o primeiro nó da lista, Tamanho, que armazena a quantidade de nós da lista, além de $\mathrm{nBloq}$, nPBloq e Tipo. Cada lista representa um vértice do grafo e, como os nós que compõem a lista representam os nós adjacentes, o atributo $\mathrm{nBloq}$ é usado para armazenar o estado do nó representado pela lista durante a simulação do programa. $O$ atributo nPBloq é utilizado durante um bloqueio para envio ou recebimento de uma mensagem. Ele sinaliza qual processo irá receber a mensagem, quando se tratar de um comando para envio de mensagem, ou de onde a mensagem está chegando, quando se tratar de um comando para recebimento de mensagem. $O$ atributo Tipo é um campo auxiliar para desenhar o grafo. Ele representa o tipo 
7.6).

Figura 7.6 - Algoritmo Aberto Pelo Protótipo.

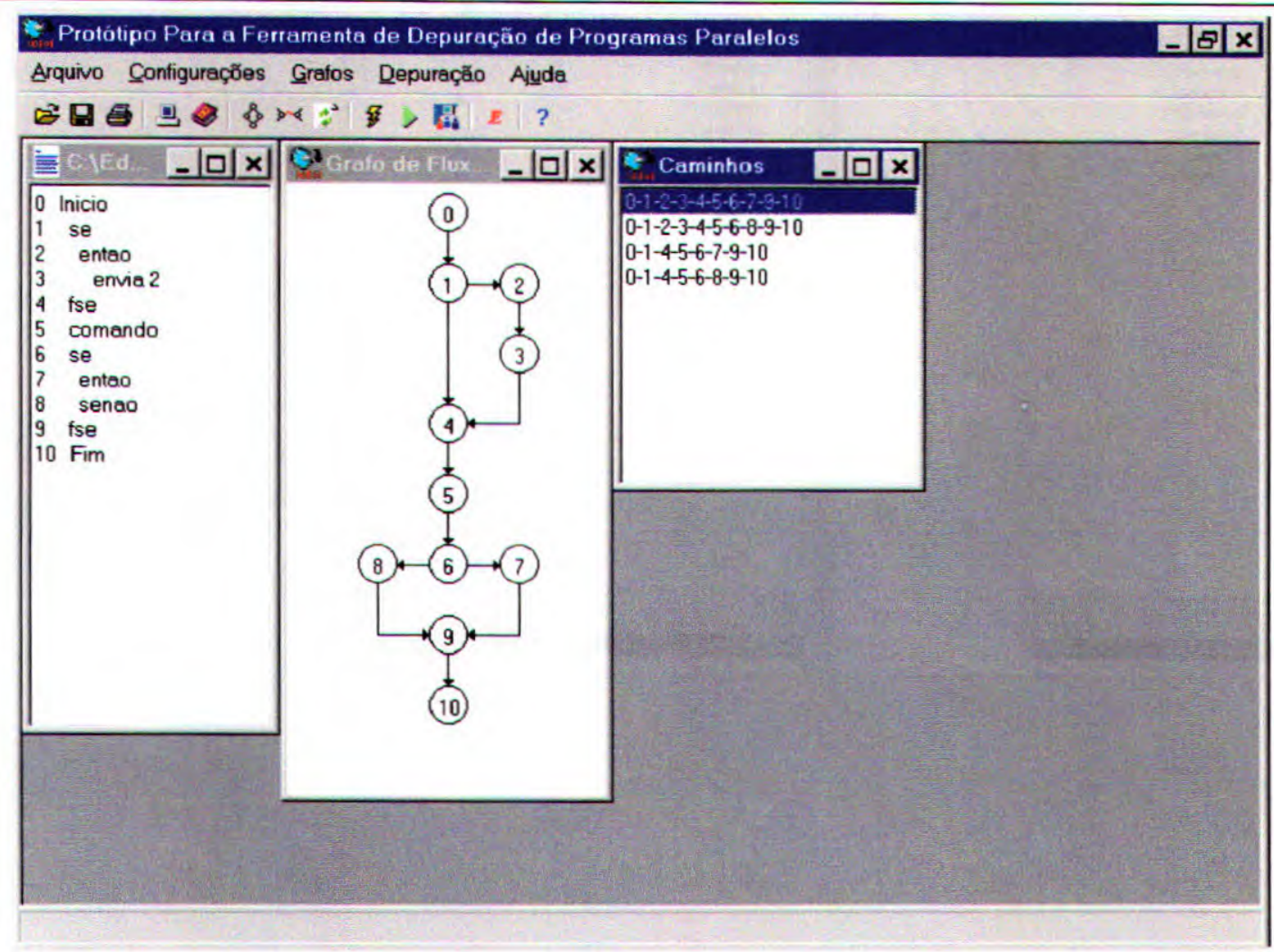

Após a abertura de todas as tarefas é possível produzir uma simulação através da criação de uma linha de controle (thread) para cada grafo. Cada linha de controle irá colorindo os nós dos seus respectivos grafos seqüencialmente, com um intervalo de tempo correspondente com a estimativa da diferença de performance de cada processador. Quando a linha de controle encontrar um comando para enviar uma mensagem Send (ENVIA) ou de recebimento de uma mensagem Receive (RECEBE), a sua execução será suspensa e só voltara à nova execução quando o usuário pedir explicitamente para a mensagem ser enviada. Nesse caso a ferramenta verifica a consistência da mensagem, ou seja, se o processo destino realmente está esperando por uma mensagem e em caso positivo libera os dois processos. A figura 7.8 apresenta os dois processos da figura 7.7 bloqueados durante a simulação.

Durante a simulação o usuário poderá verificar a situação de todas as tarefas, inclusive daquelas cujas janelas estão minimizadas, através da opção que informa os Estados dos Processos, (Os estados possíveis são: Exec - o processo está em execução; Bloq - quando o processo estiver bloqueado por um comando de envio ou de recebimento de mensagens e Morto - quando a tarefa encerrou a sua execução). A figura 7.9 apresenta os estados das tarefas da figura 7.8 no instante em que aguardam a liberação da mensagem pelo usuário. 
Figura 7.7 - Exemplo de Aplicação Paralela Aberta no Protótipo.

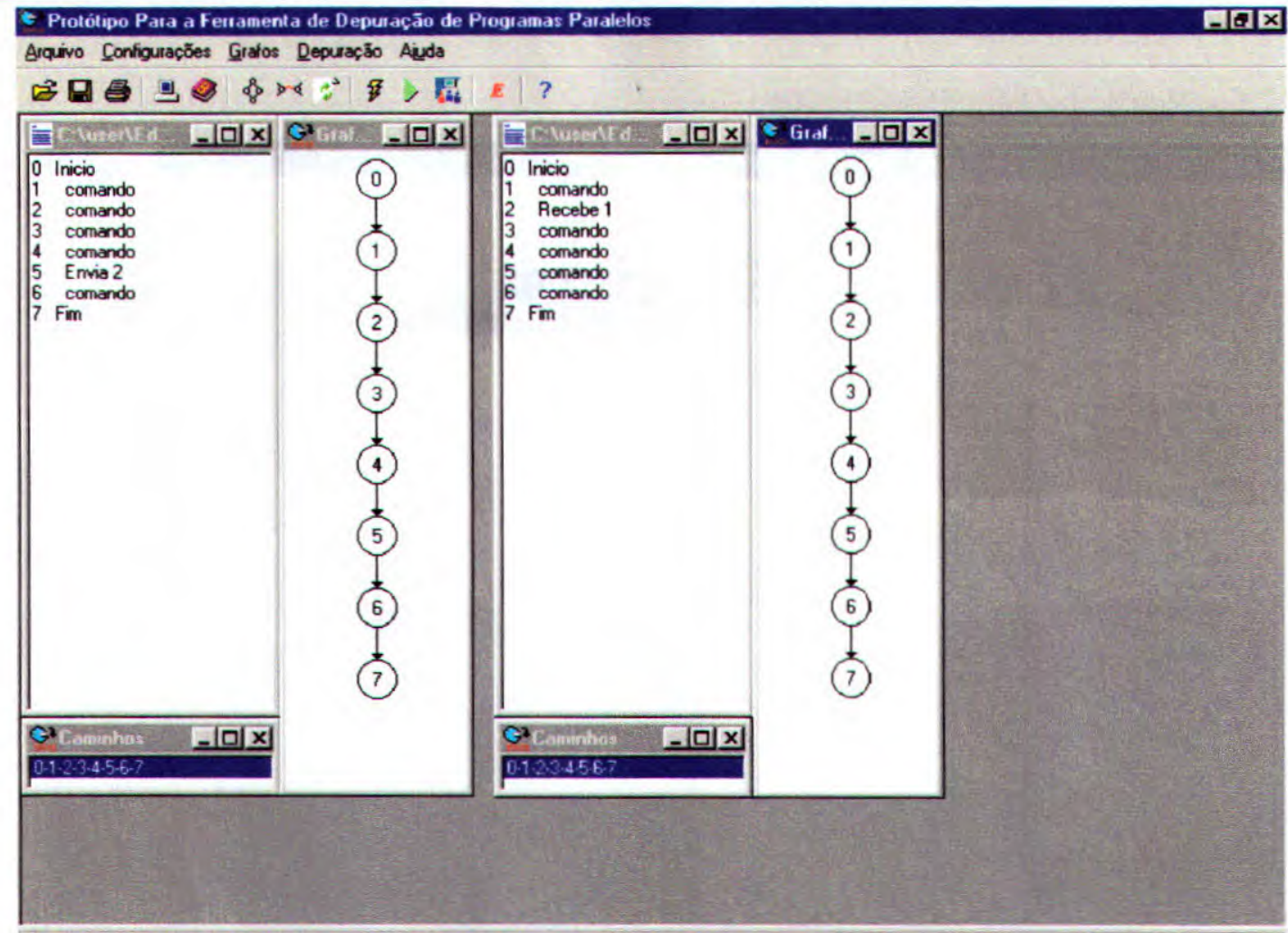

Figura 7.8 - Tarefas Bloqueadas Aguardando Liberação Pelo Usuário.

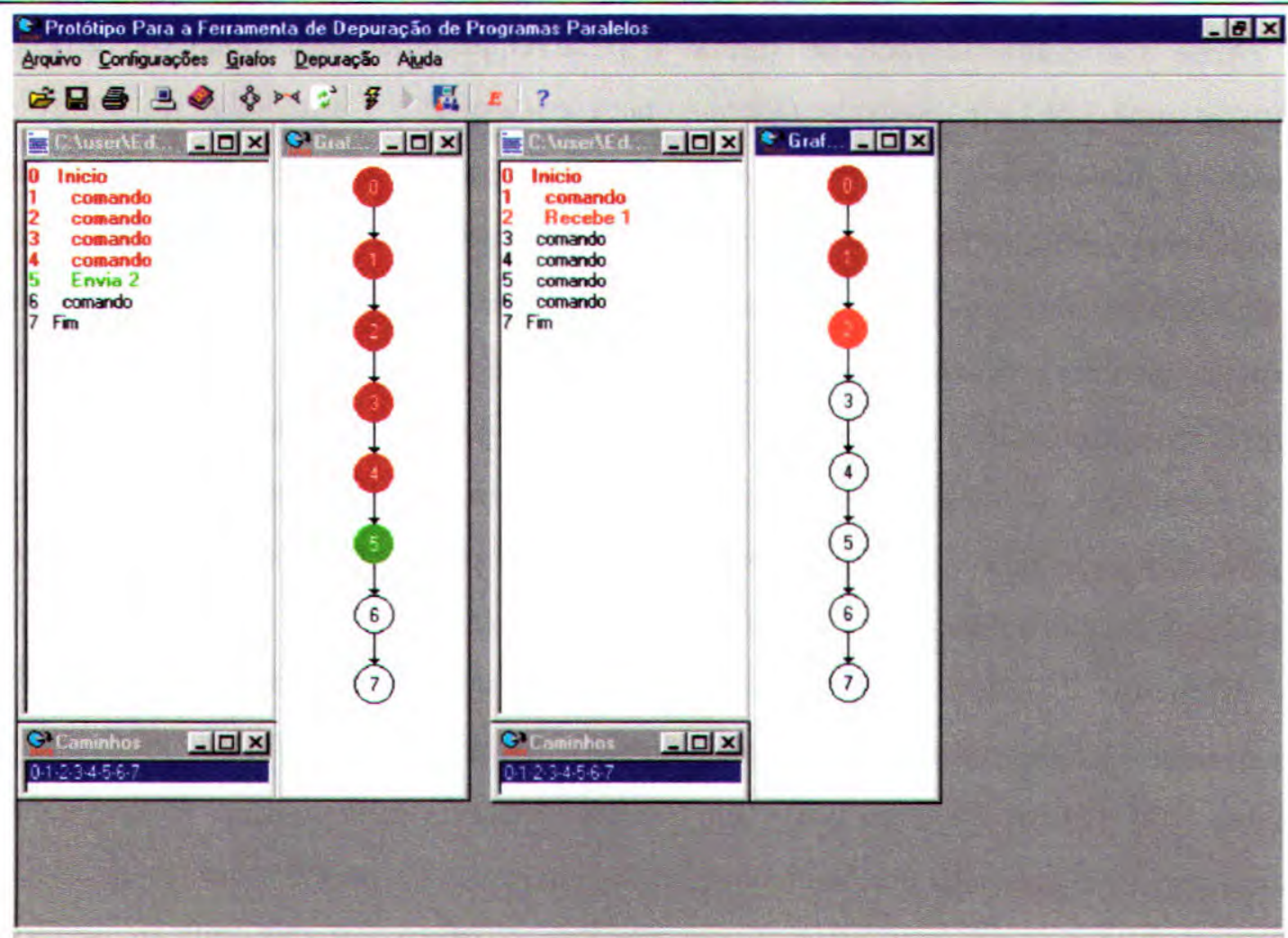


Quando o grafo gerado possuir vários caminhos o usuário irá selecionar a sequêencia que deseja que seja percorrida para cada grafo, após o reconhecimento dos caminhos pela ferramenta.

Figura 7.9 - Estado das Tarefas da Figura 7.8.

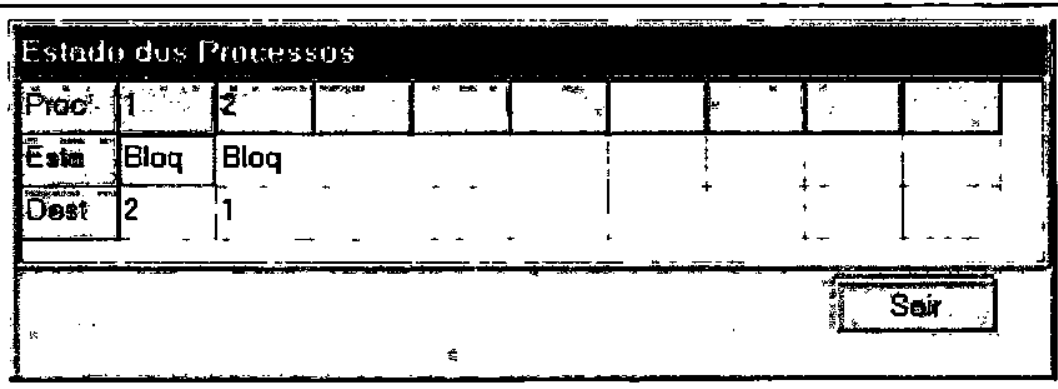

Em se tratando da depuração, o procedimento interno é semelhante. Porém, a ferramenta faz a busca nas estruturas dos grafos utilizando todos os caminhos localizados, apresentando o resultado para o usuário.

\section{3 - Estrutura Interna do Protótipo}

Algumas características desse protótipo merecem especial atenção, pois permitirão o desenvolvimento de uma versão final mais consistente.

\subsection{1 - Threads}

Com o objetivo de facilitar a implementação de aplicações com múltiplos threads, o Delphi provê a classe TThread. Utilizando essa classe, pode-se criar linhas de controle sem ser necessário o acesso direto às funções para manipulação de threads do sistema. Cada objeto TThread (ou de alguma classe derivada dela) corresponde a um thread.

A classe TThread é uma classe abstrata. Uma Classe Abstrata é uma classe que não tem instâncias diretas, mas cujas classes descendentes têm instâncias diretas. Uma classe abstrata pode definir o protocolo para uma operação sem fornecer o código correspondente. Essa operação é chamada de abstrata. Uma operação abstrata define a forma de uma operação para qual cada subclasse concreta deve providenciar sua própria implementação. A classe TThread possui um método abstrato que deve ser sobrescrito em uma classe descendente chamado Execute. Esse método é o código principal do thread e que será executado durante o ciclo de vida do objeto thread.

No protótipo foi definido a classe ThProcesso que é descendente direta da classe TThread. Os objetos instanciados a partir dessa classe controlam a simulação dos grafos do programa. Essa classe é responsável pela simulação dos grafos colorindo os caminhos que 
forem selecionados. Existe um objeto ThProcesso para cada tarefa do programa paralelo que está sendo depurado.

A listagem 7.2 apresenta a descrição da classe ThProcesso. Os objetos dessa classe são utilizados para simular o comportamento do programa através do grafo. Ela possui dois atributos privados: No- e Ant. No representa o vértice atual duraņte a sisimulação e Ant representa $O$ vértice onde fluxo se encontrava em um passo anterior. $\mathrm{O}$ atributo público $\mathrm{Eu}$ armazena o número do thread, ou seja, o número de identificação da tarefa dentro da aplicação paralela, a ferramenta atribui um número único para cada tarefa no instante em que ela é aberta ou criada. Os atributos frmG, frmP, frmc e frmE são, respectivamente, ponteiros para as janelas do grafo, do programa, dos caminhós e da janela de estados das tarefas. Com exceção da janela de estado das tarefas, que é uma janela compartilhada por todos os threads que fazem parte do processo em depuração, cada thread possui as suas próprias janelas para apresentação do grafo, do programa e dos caminhos possíveis. $O$ método Execute é relativamente simples. Inicialmente uma variável (Caminho) recebe o caminho escolhido pelo usuário. Uma função (Caminha) é sempre chamada para retornar o próximo nó a ser percorrido no caminho escolhido. Essa função retorna -1 quando todos os nós já tiverem sido percorridos. Após definido o próximo nó a ser percorrido o método Desenha é chamado com o auxilio do método definido na classe TThread Synchronize, que é responsável pela exclusão mútua no acesso ao vídeo (que é um recurso compartilhado pelos threads). O método Desenha colore o próximo nó a ser percorrido de azul, em caso de comando que não envolve paralelismo, verde em caso de um comando de envio de mensagem e vermelho em caso de comando que espera por uma mensagem. Além disso, os nós que já foram percorridos são coloridos de marrom, para que o usuário possa perceber o caminho que foi realizado até então. Esse método também colore com as mesmas cores os comandos na janela do programa correspondente. Um procedimento denominado Clock é chamado para temporizar a execução criando uma imagem do ciclo de clock da CPU. Essa informação é calculada a partir dos dados da arquitetura, podendo ser diferente para cada thread, quando se tratar de arquiteturas heterogêneas. $O$ método Desenha ainda suspende a execução dos threads que estiverem apontando para nós que representam comandos de envio e recebimento de mensagens. Esses threads só voltarão a executar quando o usuário liberar as mensagens, se isso for possível.

\subsection{2 - Utilizando Seções Críticas}

É importante notar que esse protótipo, por criar linhas de controle concorrentes, 
necessita resolver problemas de sincronização e comunicação entre elas, como nos processos que pretende depurar. Dessa forma é necessário utilizar políticas de sincronização. Como o protótipo foi desenvolvido sob a plataforma Windows, é necessário utilizar as funções de sua API que são responsáveis pela sincronização de threads e processos (disponiveis nas plataformas Win32).

Os mecanismos de sincronização no Windows são:

- Seções Críticas: as seções críticas só podem ser usadas dentro de um único processo, um único aplicativo.

- Mutexes: são objetos globais que podem ser usados para serializar o acesso a um recurso.

- Semáforos: são semelhantes aos mutexes, mas são contadores, permitindo mais de um acesso a um dado recurso ao mesmo tempo. Um mutex é equivalente a um semáforo com contagem máxima de 1 .

- Eventos: podem ser usados como um meio de sincronizar um processo com os eventos do sistema, como nas operações com arquivos.

Listagem 7.2 - Definição da Classe ThProcesso Implementada no Protótipo.
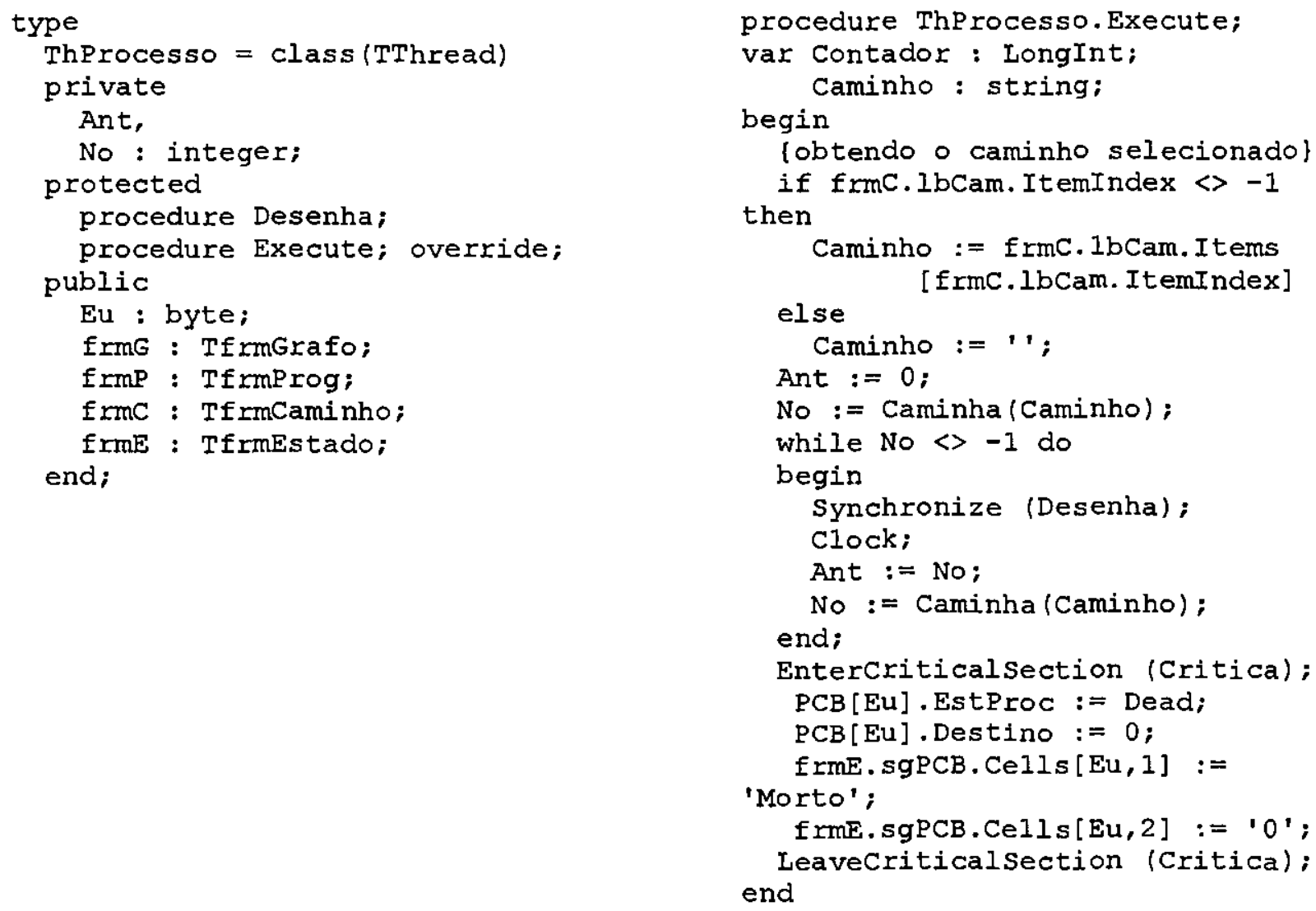
No protótipo desenvolvido, foi utilizada a técnica de seção crítica, pois é necessário controlar o acesso a uma variável compartilhada que informa os estados de todos processos denominada PCB (Process Control Block). Os métodos Desenha e Execute da classe ThProcesso utilizam os procedimentos Entercriticalsection $\mathrm{e}$ LeaveCriticalsection para entrar e sair da seção crítica respectivamente. A declaração da seção crítica (Critica) e do vetor $\mathrm{PCB}$ de estados das tarefas, além do comando de inicialização da variável Critica podem ser vistos na listagem 7.3.

Listagem 7.3 - Declaração e Inicialização da Seção Crítica e da Variável PCB.

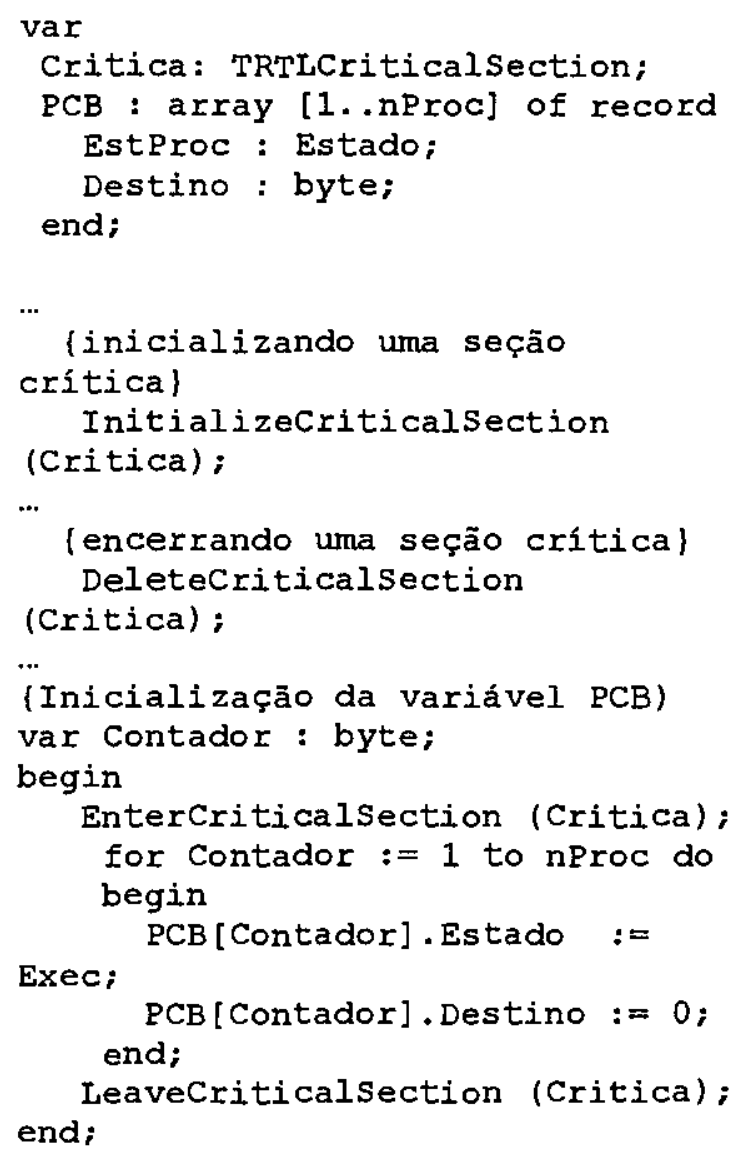




\section{4 - Considerações Finais}

O objetivo desse capitulo não foi criar um texto sobre programação; assim, não foram discutidos problemas da codificação em detalhes. $\mathrm{O}$ objetivo foi discutir a interface da ferramenta de auxílio na depuração de programas paralelos e levantar algumas considerações sobre a implementação da ferramenta.

De forma resumida, os beneficios na construção de um protótipo podem ser definidos como sendo:

- Mostrar claramente os objetivos e funcionalidades do ambiente proposto;

- Desenvolver alternativas para os problemas e detalhes relativos a implementação da ferramenta que surgem no desenvolvimento do protótipo, para que, na versão final essas situações possam ser mais facilmente resolvidas.

$\mathrm{Na}$ implementação da versão final os problemas de implementação necessitarão de uma análise mais refinada. Por exemplo, foi criada uma versão relativamente simples do algoritmo para geração dos caminhos em um grafo. Na versão final será necessário um estudo da eficiência dos algoritmos existentes, para a escolha do método mais adequado.

Antes de uma implementação final da ferramenta ainda é necessário explorar o potencial do protótipo colocando-o a disposição de alunos de programação paralela, para uma análise da interface e de sua funcionalidade. Esse passo é o cerne da abordagem de prototipação, uma vez que o usuário poderá examinar uma representação real do projeto e sugerir modificações que façam com que esta ferramenta atenda melhor as necessidades reais. 


\section{Conclusões e Trabalhos Futuros}

Começar um trabalho é geralmente uma tarefa fácil. Chegar ao seu término, porém, exige um esforço maior. No início são as dúvidas, os questionamentos, a busca do melhor caminho. E para concluir o trabalho é necessário, antes de tudo, reconhecer que ele chegou ao fim. Nesse momento é deve-se avaliar o que foi feito, quais foram as contribuições e o que ainda é possível desenvolver em trabalhos futuros.

Esse projeto enfocou duas áreas relevantes da programação paralela: o seu aprendizado e a depuração de programas paralelos.

A depuração de programas, como foi exposto durante toda a dissertação, é uma tarefa árdua e é importante abrir fronteiras para que as soluções possam ir aos poucos se tornando mais simples e mais presentes nas ferramentas de desenvolvimento de software paralelo.

A aprendizagem está presente em todas as áreas do conhecimento humano. Por mais técrica ou sofisticada que possa ser um ramo do conhecimento, são necessárias o desenvolvimento de metodologias de aprendizagem. Durante toda a execução deste trabalho estava implícito que o saber pensar se fortalece a partir do saber fazer. Uma ferramenta de depuração aliada a uma metodologia de aprendizagem permite aprimorar o senso crítico do usuário, criando oportunidades de questionamento e, conseqüentemente, aumentando o processo de ensino-aprendizagem.

A unificação dessas duas áreas, ou seja, a depuração de programas paralelos com a aprendizagem de programação paralela é a maior contribuição deste trabalho.

Além disso, o desenvolvimento do protótipo proporcionou, além do objetivo inicial, que era o projeto de um ambiente para depuração de programas paralelos e a utilização dos 
erros encontrados na aprendizagem dos usuários inexperientes, uma vantagem não esperada: a possibilidade de utilizar o próprio protótipo como ferramenta de aprendizagem de programação paralela, independentemente da necessidade de se depurar um programa, através da demonstração dos problemas e dificuldades encontradas na programação e do comportamento de várias tarefas sendo executadas em paralelo.

Dessa forma, as contribuições deste trabalho podem ser resumidas como sendo:

- O projeto de um ambiente de depuração paralela que permite ao usuário verificar o comportamento das tarefas durante a depuração, através da visualização dos caminhos que o programa pode percorrer durante a execução real do programa.

- Especificação de um ambiente amigável ao usuário iniciante, que permite motivar um número maior de usuários para a utilização da programação paralela.

- A independência de plataforma na especificação do projeto, o que permite a implementação de versões para vários ambientes de troca de mensagem.

- A possibilidade de se depurar o código do programa sem a necessidade da plataforma em que o programa foi implementado, facilitando a aprendizagem de um grande número de linguagens e bibliotecas paralelas, permitindo que cursos de programação concorrente usem a ferramenta como instrumento de aprendizagem.

- A flexibilidade de se conectar esta ferramenta com outras ferramentas de auxílio no desenvolvimento de programas paralelos [Calonêgo, 1997] [Branco, 1999], estendendo o seu uso e aplicabilidade.

- A possibilidade de servir como base para novas pesquisas sobre o tema: depuração e testes de programas paralelos no grupo de Programação Concorrente e Sistemas Distribuídos.

Após o término deste projeto foi possível definir vários outros trabalhos como, por exemplo:

- Ambiente Para Testes de Programas Paralelos: testar e depurar programas são tarefas que estão intimamente relacionadas. A ferramenta possui flexibilidade para se testar programas paralelos. Entretanto, desenvolver os casos de teste para colocá-los à prova e avaliar os resultados apresenta alguns problemas que precisam ser resolvidos. Mesmo para pequenos programas, o número de caminhos lógicos possíveis pode ser muito grande.

- Ambiente Para Simulação de Programas Paralelos: o protótipo desenvolvido neste trabalho permite simular os algoritmos paralelos. $O$ que aconteceria se as tarefas possuíssem 100 linhas de código (tarefas pequenas), ou 500 ou $1000 \ldots$... É 
necessário uma avaliação da melhor maneira de simular tarefas cujos grafos correspondentes dificultem a visualização. É importante fazer um estudo de como criar supergrafos e como eles seriam visualizados pelos usuários.

- Paralelizador Para Programas de Granulosidade Grossa: Ạs ferramentas de paralelização automática são geralmente destinadas a tarefas de granulosidade fina. A possibilidade de verificar o grau de paralelismo alcançado pelo usuário depende de formas de paralelização de procedimentos ou de tarefas inteiras.

- Criação de Versões Para Linguagens Paralelas Específicas: Agora que o projeto está pronto é preciso implementar versões para linguagens existentes. Quando isto for realizado, certamente irão surgir problemas específicos de cada linguagem que precisarão ser sanados.

- Comparação de Performance com os Depuradores Existentes: Apesar do objetivo desta ferramenta ser os usuários inexperientes, que geralmente desenvolvem projetos pequenos, é interessante verificar a extensibilidade desta ferramenta com a utilização de programas que produzam grafos com grande quantidade de nós.

- Tradutor Para Linguagens Paralelas: Após a implementação de várias versões, será possível converter um programa desenvolvido em uma linguagem ou biblioteca de troca de mensagens, para outra com características semelhantes, como por exemplo, PVM e MPI.

- Criação de Uma Versão Distribuída: Depurar grandes programas paralelos é uma tarefa quase impossivel. Muitos caminhos que os programas podem percorrer são descartados nos casos de testes. Uma possibilidade para se estender esta ferramenta será transformar essa versão seqüencial em uma versão de depuração distribuída. Para isso é preciso uma análise de toda a problemática envolvendo a paralelização do depurador.

Certamente outros trabalhos surgirão além desses. 


\section{Referências Bibliográficas}

[Aho, et. al., 1995] AHO, A.V., SETHI, R. e UllmaN, J.D. Compiladores Princípios, Técnicas e Ferramentas. Rio de Janeiro : Livros Técnicos e Científicos, 1995.

[Almasi e Gottlieb, 1994] Almasi, G. S. e GotTleB, A. Highly Parallel Computing. 2. ed. Redwood City: The Benjamin Cummings, 1994.

[Axford, 1989] AXFORD, T. Concurrent Programming - Fundamental Tecniques for RealTime and Parallel Software Design. Chichester : John Wiley \& Sons, 1989.

[Baiardi et al., 1986] BAIARDI, F.B., NicoleTtA, F., VAGLINI, G. Development of a Debugger for a Concurrent Language. IEEE Transactions On Software Engineering, v. 12, n. 4, p. 547-553, April, 1986.

[Ben-Ari, 1990] BEN-ARI, M. Principles of Concurrent and Distributed Programming. New York : British Library Cataloguing in Publication Data, 1990.

[Branco, 1999] BRANCO, K.R.L.J.C. Extensão da Ferramenta de Apoio a Programação Paralela (F.A.P.P.) para Ambientes Paralelos Virtuais. São Carlos, 1999. Dissertação (Mestrado em Ciência da Computação e Matemática Computacional) - Instituto de Ciências Matemáticas e de Computação - Universidade de São Paulo.

[Brawer, 1989] BRAWER, S. Introduction to Parallel Programming. Boston : Academic Press, 1989.

[Browne et al., 1995] BROWNE, J.C., HYDER, S.I., DONGARRA, J., MOORE, K., NEWTON, P. Visual Programming and Debugging for Parallel Computing. IEEE Parallel \& Distributed Technology, p. 75-83, 1995.

[Calônego, 1997] CAlônego JR., N. Uma Abordagem Orientada a Objetos de Uma Ferramenta de Auxilio a Programação Paralela, Tese (Doutorado), Instituto de Física e Quimica da Universidade de São Paulo (USP), Outubro, 1997.

[Cantú, 1998] Cantú, M. Dominando o Delphi 4. São Paulo : Makron Books, 1998. 
[Carvalho, 1998] CARVALHO, F. F. Programação Orientada a Objetos Usando o Delphi 3. São Paulo : Érica, 1998.

[Cheung et al., 1990] CHEUnG, W.H., BLACK, J.P., MANNING, E. A Framework for Distributed Debugging. IEEE Software, p. 106-115, Jan., 1990.

[Chi, 1985] CHI, U.H. Formal Specification of User Interfaces: A Comparison and Evaluation of Four Axiomatic Approaches. IEEE Transactions on Software Engineering, v. SE-11, n. 8, p. 671-685, Aug., 1985.

[Craveiro, 1998] CRAVEIRO, G.S. Deteç̧ão de Propriedades Estáveis em Sistemas Distribuidos. Campinas, 1998. Dissertação (Mestrado em Computação) - Instituto de Computação, Universidade Estadual de Campinas.

[Damitio e Turner, 1995] DAMITIO, M., TURNER, S. Debugging Concurrent Programs With Dynamic Slicing and Backtracking. EPSRC PPECC Workshop 'Distributed vs Parallel: convergence or divergence', April, 1995, Proceedings, p. 45-49.

[Davis, 1994] DAVIS, W.S. Análise e Projeto de Sistemas: Uma Abordagem Estruturada. Rio de Janeiro : Livros Técnicos e Científicos, 1994.

[Duncan, 1990] DUNCAN, R. A Survey of Parallel Computer Architectures. IEEE Computer, p. 5-16, Feb., 1990.

[Flynn, 1972] FLYNN, M.J. Some Computer Organizations and Their Effectiveness. IEEE Transactions on Computers, v. C-21, p. 948-960, 1972.

[Freire, 1998] FREIRE, M.E.P. O Sistema Tutor de um Ambiente Inteligente para Treinamento $e$ Ensino. São Carlos, 1998. Dissertação (Mestrado em Ciência da Computação e Matemática Computacional) - Instituto de Ciências Matemáticas e de Computação Universidade de São Paulo.

[Furtado, 1973] FURTADO, A.L. Teoria dos Grafos: Algoritmos. Rio de Janeiro : Livros Técnicos e Científicos, 1973.

[Gane, 1988] Gane, C. Desenvolvimento Rápido de Sistemas. Rio de Janeiro : Livros Técnicos e Científicos, 1988.

[Gane e Sarson, 1983] GANE, C. e SARSON, T. Análise Estruturada de Sistemas. Rio de Janeiro : Livros Técnicos e Científicos, 1983.

[Gersting, 1993] Gersting, J.L. Fundamentos Matemáticos Para a Ciência da Computação. $3^{\text {a }}$. ed., Rio de Janeiro : Livros Técnicos e Científicos, 1983.

[Gupta et al., 1998] GUPTA, N., MATHUR, A.P., SoffA, M. L. Automated Test Data Generation Using An Iterative Relaxation Method. In: ACM SIGSOFT Sixth International Symposium on Foundations of Software Engineering, Orlando, 1998, Proceedings, p. 231-244.

[Habermann, 1991] HABERMANN, F. Giving Real Meaning to 'Easy-to-use' Interfaces. IEEE Software, v. 8, n. 4, p. 90-91, July, 1991. 
[Machado e Abreu, 1995] MACHADO, F.N.R., ABREU, M. Projeto de Banco de Dados: Ur Visão Prática. São Paulo : Érica, 1995.

[McDowell e Heimbold, 1989] MCDOWEL, C.E., HELMBOLD, D.P. Debugging Concurr Programs. ACM Computing Surveys, v. 21, n. 4, p. 593-622, Dec., 1989.

[Norton e Mueller] NORTON, P., MUELIER, J. P. Perter Norton: Guia Para o Delphi 2, s Paulo: Makon Books, 1997.

[Pimentel e Direne, 1998] PIMENTEL, A.R., DrRENE, A.I. Medidas Cognitivas no Ensin de Programação de Computadores com Sistemas Tutores Inteligentes. [online].

[10/04/1999]. Disponivel na Internet:

http://anus.inf ufsc.br:1998/materiais/sbie98/anais/artigos/art36.html.

[Pressman, 1992] PRESSMAN, R.S. Software Engineering: A Practitioner's Approach, 3. London : McGraw-Hill, 1992.

[Seleções, 1975] História do Homem: Nos Últimos Dộis Milhões de Anos. In: Seleções Reader's Digest, 1975.

[Shay, 1996] SHAY, W.A. Sistemas Operacionais. SãdPaulo : Makron Books, 1996.

[Stewart e Gentleman, 1997] STEWART, D.A., GENTLEMAN, W.N. Non-Stop Monitoring a Debugging on Shared-Memory Multiprocessors. IEEE Computer Society, p. 263-26
May, 1997.

[Tanenbaum, 1992] TANENBAUM, Prentice-Hall, 1992.

A.S. Modern Operatition System. Engewood Cliff 